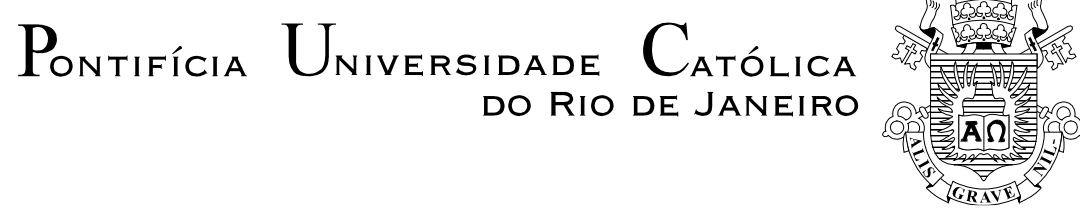

Arthur Santos Coelho

\title{
Avaliação do Comportamento Não Drenado de Areias
}

Dissertação apresentada ao Programa de PósGraduação em Engenharia Civil da PUC-Rio como requisito parcial para obtenção do grau de Mestre em Engenharia Civil.

Orientador: Prof. Alberto Sayão

Coorientador: Prof. Sandro Salvador Sandroni

Rio de Janeiro

Agosto de 2018 


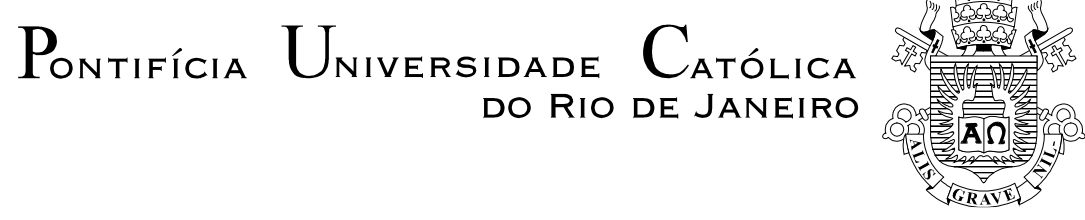

\section{Arthur Santos Coelho}

\section{Avaliação do Comportamento Não Drenado de Areias}

Dissertação apresentada como requisito parcial para obtenção do grau de Mestre pelo Programa de Pós-Graduação em Engenharia Civil da PUC-Rio. Aprovada pela Comissão Examinadora abaixo assinada.

Prof. Alberto de Sampaio Ferraz Jardim Sayão

Orientador

Departamento de Engenharia Civil e Ambiental- PUC-Rio

Prof. Sandro Salvador Sandroni

Co-Orientador

Sandro Sandroni Engenheiros Associados Ltda

Prof. Eleonardo Lucas Pereira

Universidade Federal de Ouro Preto

Prof. Rogério Luiz Feijó

Universidade do Estado Rio de Janeiro

Prof. Márcio da Silveira Carvalho

Coordenador Setorial do

Centro Técnico Científico - PUC-Rio

Rio de Janeiro, 24 de agosto de 2018. 
Todos os direitos reservados. É proibida a reprodução total ou parcial do trabalho sem autorização da universidade, do autor e do orientador.

\section{Arthur Santos Coelho}

Graduou-se em Engenharia Civil pelo Centro Federal de Educação Tecnológica Celso Suckow da Fonseca (CEFET-RJ) - Brasil. Principais áreas de interesse: barragens, geotecnia experimental, aterros sobre solos moles, pavimentação, contenções, geomecânica computacional.

Ficha Catalográfica

Coelho, Arthur Santos

Avaliação do comportamento não drenado de areias / Arthur Santos Coelho ; orientador: Alberto Sayão ; co-orientador: Sandro Salvador Sandroni. - 2018.

$86 \mathrm{f} . ; 30 \mathrm{~cm}$

Dissertação (mestrado)-Pontifícia Universidade Católica do Rio de Janeiro, Departamento de Engenharia Civil e Ambiental, 2018.

Inclui bibliografia

1. Engenharia civil e ambiental - Teses. 2. Ensaio triaxial. 3. Liquefação estática. 4. Areia fofa. 5. Estado crítico. I. Sayão, Alberto S. F. J. II. Sandroni, Sandro Salvador. III. Pontifícia Universidade Católica do Rio de Janeiro. Departamento de Engenharia Civil e Ambiental. IV. Título. 
À minha querida mãe Maria das Graças

À minha querida avó Marly À minha amada esposa Laís 


\section{Agradecimentos}

Antes de tudo, agradeço ao meu eterno Deus por tudo que tem feito, por tão grande salvação e por tamanha misericórdia. Que meu Senhor e salvador Jesus Cristo seja glorificado com este trabalho;

À minha esposa Laís, que suportou com bom ânimo os momentos difíceis presentes em qualquer pesquisa séria, me deu força e transformou dificuldades em momentos alegres;

À minha família, que sempre me incentivou e motivou ao longo da minha trajetória acadêmica, em especial à minha mãe cujo sonho era o de me ver estudar na PUC-Rio, local onde ela dedicou mais de 15 anos de trabalho. Também à minha querida avó Marly que sempre esteve comigo;

Aos meus orientadores, Alberto Sayão e Sandro Sandroni, que sempre apresentaram comentários pertinentes jogando luz em caminhos escuros, direcionando este trabalho com dedicação, cuidado e profissionalismo;

O presente trabalho foi realizado com apoio da Coordenação de Aperfeiçoamento de Pessoal de Nível Superior - Brasil (CAPES) - Código de Financiamento 001;

À Samarco Mineradora S.A. por ceder parte das amostras usadas neste trabalho;

A toda a equipe do laboratório de Geotecnia da PUC-Rio, em especial ao amigo Amauri pelo incentivo, trabalho e conversas. Aos meus colegas de curso, Raul, Bruno, Andreia, Fernanda, Carolina, Felipe e Arthur Amaral, sem eles os momentos de estudo não seriam tão alegres;

Ao professor Eleonardo (UFOP) pela paciência e fundamental colaboração na realização dos ensaios triaxiais. 


\section{Resumo}

Coelho, Arthur Santos; Sayão, Alberto de Sampaio Ferraz Jardim; Sandroni, Sandro Salvador. Avaliação do Comportamento Não Drenado de Areias. Rio de Janeiro, 2018. Dissertação de Mestrado Departamento de Engenharia Civil e Ambiental, Pontifícia Universidade Católica do Rio de Janeiro.

Muitos autores concordam que areias em estado fofo, sob carregamento não drenado crescente e granulometria favorável à liquefação, necessariamente liquefazem em algum momento. Este trabalho tem como objetivo principal avaliar se duas amostras de areia, com características muito distintas uma da outra, submetidas às mesmas condições descritas acima, entram em liquefação. A primeira amostra é uma areia limpa que foi extraída de um aterro hidráulico localizado em Camboinhas, Niterói, RJ, Brasil. A segunda é um rejeito arenoso de ferro extraído de uma barragem de rejeitos localizada em Mariana, MG, Brasil. As avalições foram feitas através de ensaios de compressão triaxial com deformação controlada. Avaliou-se o comportamento desses materiais em condições de baixa compacidade e sob diferentes tensões de confinamento, com a finalidade de observar se ocorreria a liquefação. Em caso de não ocorrência da liquefação, o objetivo era compreender os motivos de tal resposta e no caso de ocorrência, avaliar a influência da tensão de confinamento, assim como delimitar as zonas de instabilidade não drenada. Verificou-se que a areia de Camboinhas entrou em liquefação total apenas para tensões de confinamento baixas, e apresenta comportamento oposto ao comportamento normal de solos arenosos fofos, tendo baixa resistência à liquefação em baixa tensão de confinamento e alta resistência à liquefação em grandes tensões de confinamento. $O$ rejeito arenoso de Mariana entrou em liquefação total em tensões de confinamento baixas e altas. $O$ rejeito apresentou comportamento diferente da areia de Camboinhas e semelhante ao comportamento normalmente obtido em solos arenosos fofos sob condições não drenadas. 


\section{Palavras - chave}

Liquefação estática; ensaio triaxial; areia fofa; estado crítico. 


\section{Abstract}

Coelho, Arthur Santos; Sayão, Alberto de Sampaio Ferraz Jardim (Advisor); Sandroni, Sandro Salvador (Co-Advisor). Assessment of the undrained behavior of Sands. Rio de Janeiro, 2018. Dissertação de Mestrado - Departamento de Engenharia Civil e Ambiental, Pontifícia Universidade Católica do Rio de Janeiro.

Many authors agree that loose sands, under increasing undrained loading and liquefaction favorable granulometry, necessarily liquefy at some moment. This work has as main objective to evaluate if two sand specimens, with characteristics very different from each other, under the same conditions as described above, enter into liquefaction. The first specimen is a clean sand that was extracted from a hydraulic embankment located in Camboinhas, Niterói, RJ, Brazil. The second is a sandy tailing of iron extracted from a tailing dam located in Mariana, MG, Brazil. The evaluations were made through triaxial compression tests with controlled deformation. The behavior of these materials was evaluated under conditions of low compactness and under different confininig pressure, in order to observe if liquefaction would occur. In case of no liquefaction, the objective was understand the reasons for such response and in case of occurrence, evaluate the influence of the confining pressure, as well as mark the zones of instability undrained. It was verified that the Camboinhas sand entered in total liquefaction only for low confining pressure, and it has the opposite behavior to the normal behavior of loose granular soils, having low strength to liquefaction in low confining pressure and high strength to liquefaction in large confining pressure. The Mariana granular tailing also entered in total liquefaction for low and higth confinig pressure. The tailing showed different behavior of the Camboinhas sand and similar to the behavior normally obtained in loose granular soils under undrained conditions. 


\section{Keywords}

Static liquefaction; triaxial tests; loose sand; critical state. 


\section{Sumário}

1 Introdução 19

1.1. Objetivos 20

1.2. Organização da Dissertação 20

2 Liquefação Estática 22

2.1. Casos Históricos 22

2.1.1. Barragem Fort Peck (EUA, 1938) 22

2.1.2. Barragem de Rejeitos Merriespruit (África do Sul, 1994) 24

2.1.3. Mina de Sullivan (Canadá, 1991) 26

2.1.4. Barragem de Fundão (Brasil, 2015) 26

2.2. Conceitos Básicos 28

2.2.1. Respostas Durante um Carregamento Não Drenado 28

2.2.2. Estado Crítico e Estado Permanente 30

2.2.3. Fluxo por Liquefação e Mobilidade Cíclica 33

2.2.4. O Conceito de Superfície de Colapso 35

2.3. Características e Condições que Influenciam a Liquefação 39

2.3.1. Influência da Granulometria e Teor de Finos 39

2.3.2. Influência da Forma dos Grãos 42

2.3.3. Influência da Composição mineralógica 42

2.3.4. Influência da Saturação 42

2.3.5. Influência da Permeabilidade 43

2.3.6. Liquefação em Depósitos Naturais 44

2.3.7. Influência da Velocidade de Carregamento 44

2.3.8. Influência da Tensão de Confinamento 45

2.3.9. Influência da Densidade Relativa 47

3 Programa Experimental 49

3.1. Caracterização Geotécnica das Amostras 49

3.1.1. Determinação da Massa Específica dos Grãos (үs) 49

3.1.2. Distribuição Granulométrica das Amostras 50 
3.1.3. Determinação dos Índices de Vazios Máximo e Mínimo

3.1.4. Forma dos Grãos

3.2. Comportamento Tensão-Deformação Sob Condições Não

Drenadas

3.2.1. Equipamento e Procedimento de Moldagem 54

3.2.2. Saturação das Amostras $\quad 58$

3.2.3. Adensamento das Amostras 58

3.2.4. Cisalhamento das Amostras $\quad 59$

3.2.5.Resultados Obtidos 60

4 Avaliação dos Resultados Obtidos 64

4.1. Granulometria 64

4.2. Ensaios Triaxiais $\quad 65$

4.2.1. Zona de Instabilidade Não Drenada 67

4.2.2. Efeito da Tensão de Confinamento 70

5 Conclusões e Sugestões $\quad 74$

5.1. Conclusões 74

5.2. Sugestões para futuros trabalhos 76

6 Referências bibliográficas $\quad 77$

Apêndice 1 - Resultados dos Ensaios Triaxiais da Areia de

Camboinhas.

Apêndice 2 - Resultados dos Ensaios Triaxiais do Rejeito Arenoso de Mariana. 


\section{Lista de Figuras}

Figura 2.1 - Vista aérea da Ruptura de Fort Peck (Jefferies e Been,

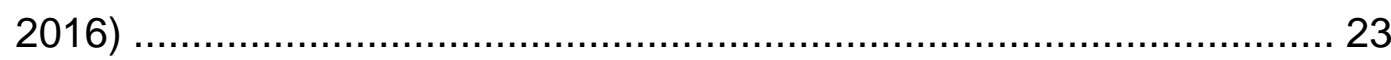

Figura 2.2 - Granulometria e linha de estado crítico dos rejeitos de Merriespruit. (Adaptado de Fourie et al, 2001) ................................... 25 Figura 2.3 - Distribuição do índice de vazios "in situ" obtidos em investigação pós-ruptura. (Adaptado de Fourie et al, 2001) ................... 25 Figura 2.4 - Ruptura da Barragem de rejeitos da Mina de Sullivan (Davies et al., 2002). 26

Figura 2.5 - Ruptura da Barragem de Rejeitos de Fundão. (Morgenstern et al, 2016) 28

Figura 2.6 - Resultados de ensaios triaxiais não drenados em areia para quatro densidades diferentes. As amostras foram consolidadas para 70kPa. (Adaptado de Healy, 1963). 29

Figura 2.7 - Comportamento de Areias Fofas e Compactas durante o cisalhamento (Adaptado de Washington University, 2008). 31

Figura 2.8 - Linha de índice de vazios crítico. (Adaptado de Castro, 1969)

Figura 2.9 - Ensaios não drenados em amostras de areia. (Adaptado de Castro e Poulos, 1977) 34

Figura 2.10 - Resultados de ensaios triaxiais não drenados. (Adaptado de Sladen et al., 1985) 35

Figura 2.11 - Ensaios triaxiais não drenados sobre areia fofa. (Adaptado de Castro et al., 1982) 36

Figura 2.12 - Superfície de colapso. (Adaptado de Sladen et al., 1985) . 37 Figura 2.13 - Superfície de colapso no espaço p' - q. (Adaptado de Sladen et al., 1985) 38

Figura 2.14 - Limites Granulométricos de Suscetibilidade à Liquefação (Adaptado de Terzaghi et al., 1996)

Figura 2.15 - Limites granulométricos dos materiais suscetíveis à liquefação proposto por Ishihara et al (1980). (Pereira, 2005) 41 
Figura 2.16- Resultados de tipo CIU em amostras de minério de ferro sob velocidade de carregamento diferentes. (Pereira, 2005) .... 45

Figura 2.17 - Trajetórias de tensões efetivas. (Adaptado de Lee, 1965)

Figura 2.18 - Tensão de desviadora vs. deformação axial. (Adaptado de Lee, 1965). 45

Figura 2.19 - Trajetórias de tensões efetivas para a areia de Nevada. (Adaptado de Yamamuro e Lade, 1997)..... 46

Figura 2.20 - Curvas tensão deformação para a areia de Nevada. (Adaptado de Yamamuro e Lade, 1997). 46

Figura 2.21 - Ensaios de compressão isotrópica sobre as areias de Nevada, Ottawa e Sacramento em diferentes densidades iniciais. 47

Figura 2.22 - Trajetória de tensões efetivas para areia de Nevada com $\mathrm{Dr}=22 \%$. (Adaptado de Yamamuro e Lade, 1997). 48

Figura 2.23 - Trajetória de tensões efetivas para areia de Nevada com $\mathrm{Dr}=31 \%$. (Adaptado de Yamamuro e Lade, 1997)..... 48

Figura 3.1 - Curva granulométrica da amostra de Mariana.................... 50

Figura 3.2 - Curva granulométrica da amostra de Camboinhas.............. 51

Figura 3.3 - Areia de Camboinhas ampliada 50 vezes. .......................... 53

Figura 3.4 - Areia de Mariana ampliada 50 vezes.................................. 53

Figura 3.5 - Areia de Mariana ampliada 200 vezes............................... 54

Figura 3.6 - Base da célula triaxial usada............................................ 55 Figura 3.7 - (i) medido de variação de volume; (ii) painel de controle de pressões; (iii) LVDT; (iv) célula de carga; (v) transdutor de pressão; (vi) câmara de acrílico com grades; (vii) sistema de engrenagens para controle de velocidade de cisalhamento. (SENEZ, 2016) .................................. 56

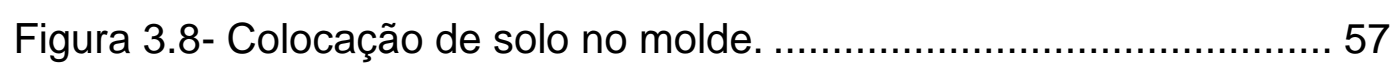

Figura 3.9- Finalização da colocação de solo no molde......................... 57

Figura 3.10 - Curvas tensão desviadora e excesso de poropressão em função da deformação para a areia de Camboinhas. ............................. 60 Figura 3.11 - Trajetória de tensões efetivas tipo MIT para a areia de Camboinhas. 61 
Figura 3.12 - Parâmetro A de poropressão em função da deformação para a areia de Camboinhas.

Figura 3.13 - Curvas tensão desviadora e excesso de poropressão em função da deformação para o rejeito arenoso de Mariana. 62 Figura 3.14 - Trajetória de tensões efetivas tipo MIT para o rejeito arenoso de Mariana. 62

Figura 3.15 - Parâmetro A de poropressão em função da deformação para o rejeito arenoso de Mariana. 63

Figura 4.1- Curva granulométrica da areia de Camboinhas e limites de Ishihara et al. (1980). 65

Figura 4.2 - Curva granulométrica de Mariana e limites de Ishihara et al. (1980). 65

Figura 4.3 - Linhas de instabilidade e ruptura para a areia de Camboinhas. 68

Figura 4.4 - Zona de instabilidade não drenada da areia de Camboinhas. 69

Figura 4.5 - Linhas de instabilidade e ruptura para a areia de Mariana. 70

Figura 4.6 - Zona de instabilidade não drenada da areia de Mariana...... 70 Figura 4.7 - Aumento da resistência à liquefação com o aumento da tensão confinante. 71

Figura 4.8 - Tensão desviadora crítica normalizada pela tensão desviadora de pico e ajuste linear para a areia de Camboinhas 72 Figura 4.9 - Tensão desviadora crítica normalizada pela tensão desviadora de pico e ajuste polinomial para o rejeito arenoso de Mariana. 73 


\section{Lista de Tabelas}

Tabela 3.1- Massa específica dos grãos das amostras estudadas. ........50

Tabela 3.2 - Percentual da amostra de Mariana. ...................................51

Tabela 3.3 - Percentual da amostra de Camboinhas. ..........................51

Tabela 3.4 - Índices de vazios máximo e mínimo das amostras. ............52 


\section{Lista de Símbolos}

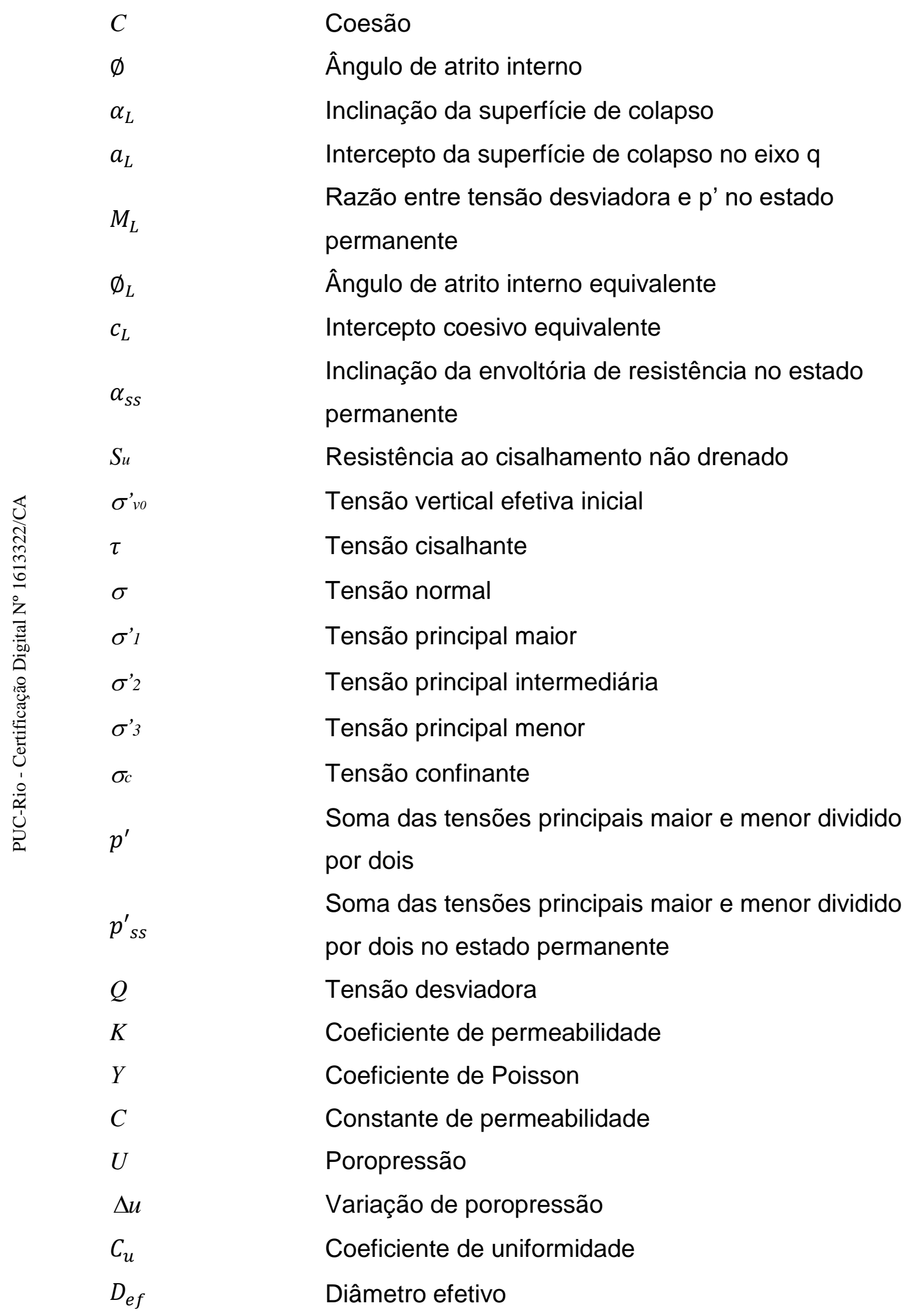




\begin{tabular}{|c|c|}
\hline$D_{10}$ & $\begin{array}{l}\text { Diâmetro das partículas correspondente à 10\% da } \\
\text { porcentagem acumulada que passa }\end{array}$ \\
\hline$D_{50}$ & $\begin{array}{l}\text { Diâmetro das partículas correspondente à } 50 \% \text { da } \\
\text { porcentagem acumulada que passa }\end{array}$ \\
\hline E & Índice de vazios \\
\hline$e_{\text {crit }}$ & Índice de vazios no estado crítico \\
\hline$e_{m a ́ x}$ & Índice de vazios máximo \\
\hline$e_{m i n}$ & Índice de vazios mínimo \\
\hline$D_{r}$ & Densidade relativa \\
\hline$\gamma s$ & Massa específica dos grãos \\
\hline$\psi$ & Parâmetro de estado \\
\hline
\end{tabular}




\section{Lista de Abreviaturas}

CIU Consolidado isotopicamente e não drenado

CID Consolidado isotopicamente e drenado

LVDT Transdutor de deslocamento vertical

LEC Linha de estado crítico

LFL Linha de fluxo por liquefação

MIT Massachusetts Institute of Technology

NBR Norma Brasileira 


\section{Introdução}

A liquefação estática de solos é um fenômeno que vem sendo largamente estudado desde a década de trinta quando foi constatado que o rompimento da barragem de Fort Peck (EUA, 1938) foi devido a esse fenômeno. Desde então, diversos autores dedicaram, e ainda dedicam, grande esforço para uma melhor compreensão do fenômeno da liquefação estática.

Atualmente, acredita-se que esse fenômeno ocorre sob condições específicas e em materiais arenosos, com exceção de argilas altamente sensíveis (Lambe e Whitman, 1969). Muitos autores acreditam que areias em estado fofo, sob carregamento não drenado crescente e que apresentem granulometria suscetível à liquefação, necessariamente entrariam em liquefação em algum momento.

A motivação deste trabalho veio a partir de conversas entre os orientadores e o presente autor a respeito do tema. A questão chave inicialmente formulada foi: qualquer areia enquadrada no padrão especificado anteriormente entraria em liquefação naquelas condições? Com base nesta pergunta chave e com o objetivo de compreender as particularidades do fenômeno da liquefação estática, duas amostras de areia foram estudadas e avaliadas, a primeira foi uma areia limpa extraída de um aterro hidráulico localizado em Camboinhas, Niterói, RJ, Brasil. A segunda foi um rejeito arenoso de ferro extraído de uma barragem de rejeitos localizada em Mariana, MG, Brasil.

As amostras apresentam características bem diferentes, sendo a areia de Camboinhas uma areia natural de praia e o rejeito arenoso de Mariana o resultado de diversos processos físico-químicos. A intenção era a de observar qual seria o comportamento de dois materiais bem distintos um do outro, submetidos as mesmas condições de ensaio. 
As avalições foram feitas através de ensaios triaxiais de deformação controlada tipo CIU. Avaliou-se o comportamento desses materiais em condições de baixa compacidade e sob diversas tensões de confinamento, com a finalidade de observar se ocorreria a liquefação. Em caso de não ocorrência da liquefação, o objetivo era o de compreender os motivos de tal resposta e, no caso de ocorrência, avaliar a influência da tensão de confinamento nas respostas dos materiais estudados, assim como delimitar as zonas de instabilidade não drenada.

\section{1.}

Objetivos

O objetivo principal é avaliar se as amostras disponíveis se liquefazem sob carregamento estático não drenado.

Os objetivos secundários são:

- Compreender as particularidades do fenômeno da liquefação estática da areia limpa de Camboinhas e do rejeito arenoso de Mariana.

- Observar a influência da tensão confinante no fenômeno da liquefação estática para as duas amostras;

- Delimitar a zona de instabilidade não drenada das duas amostras.

\section{2.}

\section{Organização da Dissertação}

O trabalho está dividido em seis capítulos. O capítulo um apresenta a introdução do assunto estudado, os objetivos, metodologia e organização da dissertação.

No capítulo dois é apresentada uma conceituação teórica do fenômeno da liquefação estática, incluindo alguns casos históricos, os conceitos básicos para a compreensão do fenômeno e as variáveis que influenciam a ocorrência da liquefação estática.

O capítulo três apresenta o programa experimental executado para avaliar a suscetibilidade à liquefação das amostras em estudo, esse 
programa é composto basicamente por ensaios triaxiais tipo CIU de deformação controlada e ensaios de caracterização geotécnica.

O capítulo quatro discute os resultados apresentados no programa experimental. Essa discussão é dividida em duas etapas. A primeira delimita a zona de instabilidade não drenada para as duas amostras estudadas. A segunda, avalia a influência da tensão confinante para a ocorrência da liquefação.

O capítulo cinco apresenta as conclusões do presente trabalho e sugestões para trabalhos futuros.

O capítulo seis, lista as referências bibliográficas consultadas para elaboração do presente trabalho. 


\section{Liquefação Estática}

Este capítulo apresenta conceitos gerais referentes à liquefação estática de areias, alguns casos históricos documentados no Brasil e no mundo. Aborda os principais conceitos de mecânica dos solos aplicados ao entendimento da liquefação, além da influência de algumas propriedades do solo na ocorrência da liquefação estática.

\section{1.}

\section{Casos Históricos}

Dentre outros, os casos históricos aqui expostos demonstram a importância do avanço nas pesquisas relacionadas ao fenômeno da liquefação estática. Serão abordados os casos da Barragem de Fort Peck (EUA), Barragem de Rejeitos de Merriespuit (África do Sul), Mina Sullivan (Canadá) e Barragem de Rejeitos de Fundão (Brasil).

\subsection{1.}

\section{Barragem Fort Peck (EUA, 1938)}

A barragem Fort Peck é um exemplo clássico de ruptura por liquefação estática. A construção da barragem foi iniciada em 1934 no rio Missouri, em Montana, ao sul da fronteira canadense. A construção foi feita por aterro hidráulico. As areias do rio e os solos aluviais de grão fino foram bombeados ao longo das bordas externas do aterro, formando assim praias inclinadas em direção ao núcleo central. A distribuição resultante de material depositado foi do mais grosso na borda externa do aterro para o mais fino no núcleo. A fundação consistiu em areias aluviais, cascalhos e argilas. (Jefferies e Been, 2016)

Um grande deslizamento ocorreu a montante da barragem perto do final da construção em 1938. No momento da ruptura, a barragem tinha cerca de $60 \mathrm{~m}$ de altura com uma inclinação média de 4H:1V. A ruptura ocorreu em uma seção de $500 \mathrm{~m}$ e foi precedida por saliências ao menos 12 horas antes da ruptura. Em algum momento, após essas tensões iniciais, um deslizamento fluido se desenvolveu, com deslocamentos muito grandes (até $450 \mathrm{~m}$ ) e inclinações finais muito pequenas (20H:1V). Cerca 
de 7,5 milhões de $\mathrm{m}^{3}$ de material estavam envolvidos na ruptura e oito homens perderam a vida. A Figura 2.1 mostra uma visão aérea da ruptura da Barragem Fort Peck, ilustra a natureza do escorregamento e a grande distância percorrida pela massa rompida (Jefferies e Been, 2016).

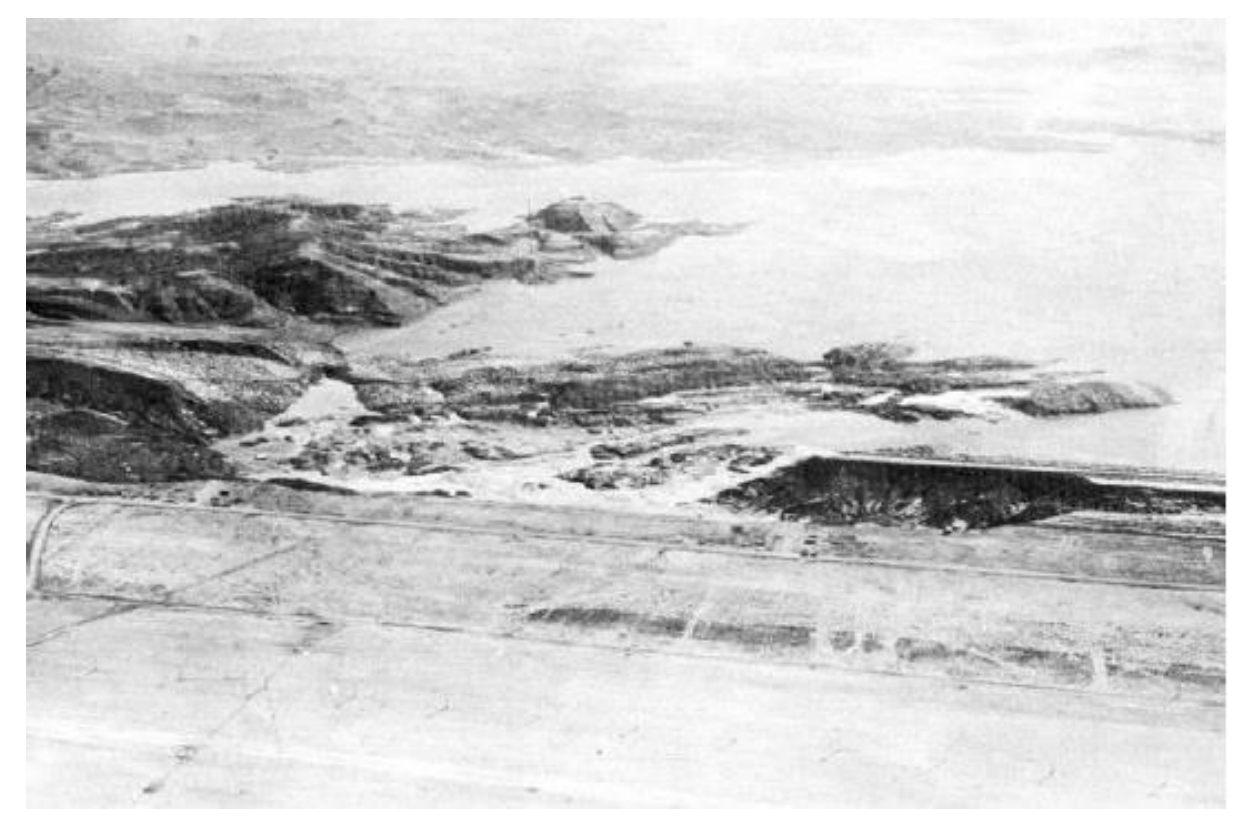

Figura 2.1 - Vista aérea da Ruptura de Fort Peck (Jefferies e Been, 2016)

O deslizamento da Barragem Fort Peck foi investigado por um painel com nove membros, chegando a conclusões diversas sobre a causa da ruptura. A maioria do conselho concluiu que o deslizamento foi causado pela ruptura cisalhante na fundação xistosa e que "a extensão do deslizamento a montante pode ter sido devida, em algum grau, a uma liquefação parcial do material durante o deslizamento". A visão da minoria (incluindo Casagrande) era que "a liquefação havia sido desencadeada pela ruptura cisalhante no xisto e que a grande magnitude da ruptura era, principalmente, devido à liquefação". Curiosamente, Casagrande (1975) relata que foi forçado a concluir que a areia localizada abaixo da linha de estado crítico também pode liquefazer. Estudos do Army Corp of Engineers, logo após o deslizamento, indicam que a densidade relativa da areia era da ordem de $45 \%$ a $50 \%$.

A ruptura da Barragem Fort Peck é importante pois parece ter efetivamente posto fim à prática de construção em aterro hidráulico das barragens de acumulação de água nos Estados Unidos (Jefferies e Been, 2016). 


\subsection{2.}

\section{Barragem de Rejeitos Merriespruit (África do Sul, 1994)}

A ruptura da barragem de rejeitos de ouro Merriespruit em 1994 foi a primeira ocorrência de ruptura catastrófica por liquefação na África do Sul. Fourie et al. (2001) argumentam que os rejeitos estavam em um estado "in situ" muito fofo e que o galgamento e a erosão do talude estabilizante expuseram esse material, resultando em liquefação estática dos rejeitos e, consequentemente, em ruptura.

A ruptura da barragem de rejeitos Merriespruit ocorreu algumas horas após uma tempestade que gerou cerca de $50 \mathrm{~mm}$ de precipitação. Aproximadamente $600 \mathrm{mil} \mathrm{m}^{3}$ de rejeitos foram despejados e fluíram por 3 $\mathrm{km}$ a jusante da barragem. A principal causa da ruptura foi o galgamento, que resultou na remoção em grande escala da face do talude. A remoção de rejeitos do talude externo deixou os rejeitos do interior da barragem expostos.

Fourie et al. (2001) abordam a questão da natureza e do estado dos rejeitos que se liquefizeram e fluíram. Eles examinaram amostras dos rejeitos remanescentes, colhidos em amostradores tipo Shelby. Em primeiro lugar, era evidente que não havia uma distribuição de tamanho de partícula única, mas sim uma ampla gama com conteúdo de finos variando de $40 \%$ a $100 \%$. Cerca de $60 \%$ das amostras apresentaram conteúdo de finos superior a 80\%. Fourie et al (2001) testaram uma seleção de amostras para determinar a linha de estado crítico, os resultados estão mostrados na Figura 2.2.

A distribuição do índice de vazios "in situ" é mostrada na Figura 2.3. Uma comparação simples das Figuras 2.2 e 2.3 mostra que grande parte dos rejeitos estava em um estado fofo bem acima da linha de estado crítico, o que configura condições propícias para liquefação. 

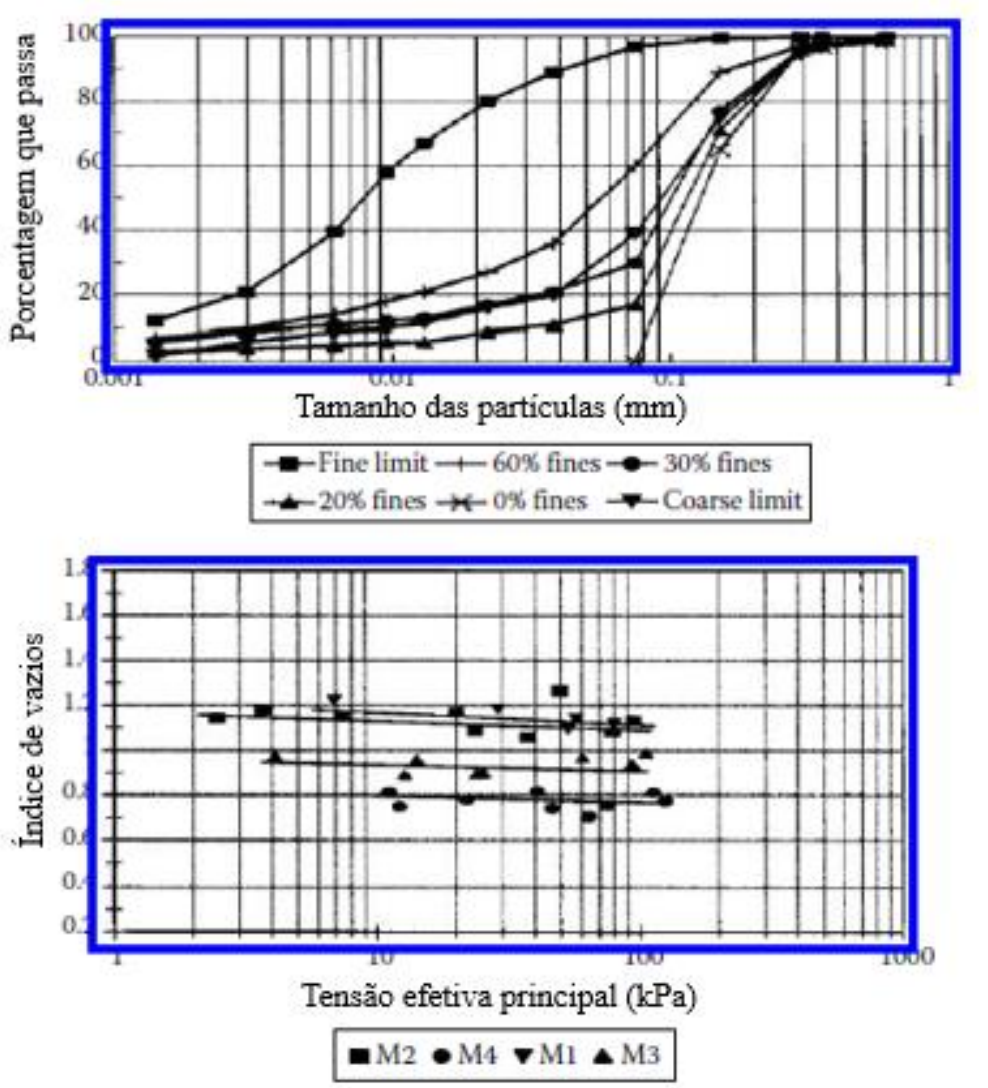

Figura 2.2 - Granulometria e linha de estado crítico dos rejeitos de Merriespruit. (Adaptado de Fourie et al, 2001)

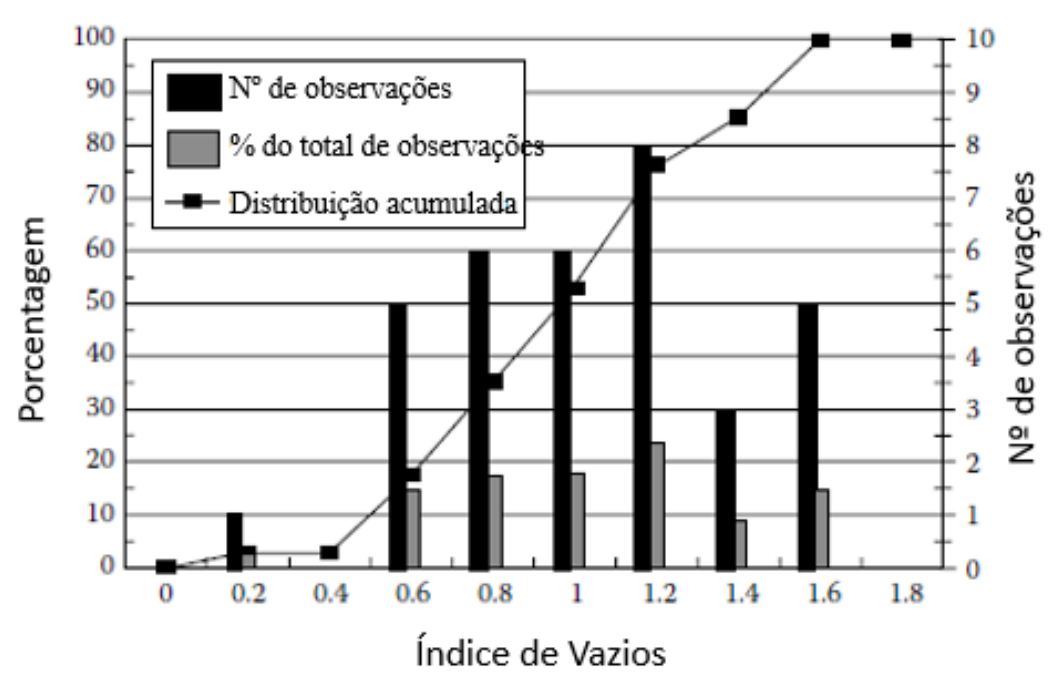

Figura 2.3 - Distribuição do índice de vazios "in situ" obtidos em investigação pósruptura. (Adaptado de Fourie et al, 2001)

Fourie et al. (2001) afirmam que um mecanismo de gatilho teve que se desenvolver antes que os rejeitos se liquefizessem. Se o represamento dos rejeitos tivesse sido operado de acordo com os regulamentos e se os níveis de água tivessem sido bem geridos, a ruptura por liquefação não teria ocorrido. Uma outra lição dessa ruptura é a influência da quantidade de água: a quantidade de água presente no reservatório é diretamente proporcional a extensão do fluxo numa eventual ruptura por liquefação. 


\subsection{3.}

\section{Mina de Sullivan (Canadá, 1991)}

Em agosto de 1991, aconteceu um evento de liquefação estática no empilhamento de rejeitos da mina de Sullivan, no Canadá.

O único gatilho gerador da ruptura por liquefação foi a presença de um dique, o qual tinha um talude de jusante de aproximadamente $1 \mathrm{~V}: 3 \mathrm{H}$, com altura máxima de $25 \mathrm{~m}$, que impôs tensões que ultrapassaram a superfície de colapso dos rejeitos da fundação. Observou-se também a geração de "sand boils". (Jefferies e Been, 2016)

Foram feitas investigações geotécnicas pós-ruptura, as quais indicaram que o rejeito se encontrava em estado fofo, com parâmetros de estado variando de $\Psi=+0,01$ a $\Psi=+0,12$, o parâmetro de estado é diferença entre o índice de vazios "in situ" e o índice de vazios no estado crítico para uma dada tensão de confinamento. O valor médio das razões

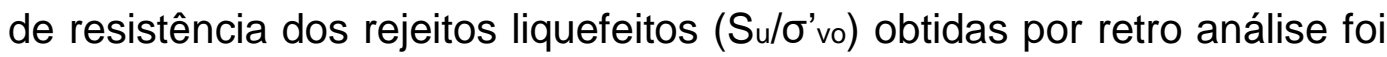
de 0,08 (Jefferies e Been, 2016).

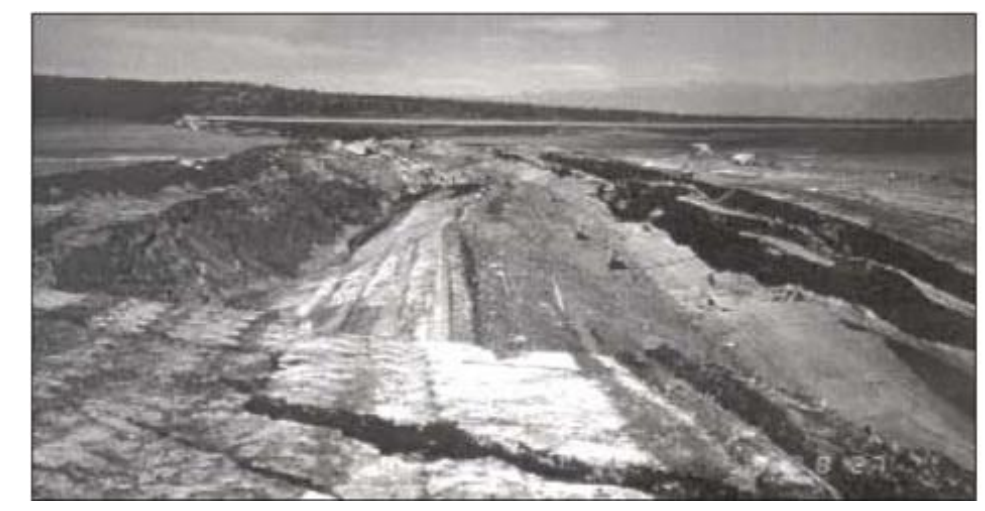

Figura 2.4 - Ruptura da Barragem de rejeitos da Mina de Sullivan (Davies et al., 2002).

\subsection{4.}

\section{Barragem de Fundão (Brasil, 2015)}

A Barragem de Rejeitos de Fundão, localizada na cidade de Mariana, MG, Brasil, rompeu em 05 de novembro de 2015 através de um deslizamento fluido que liberou cerca 32,4 milhões de $\mathrm{m}^{3}$ por $600 \mathrm{Km}$, deixando 19 mortes. Um comitê de consultores analisou as causas do colapso e concluiu que a ruptura foi provocada por liquefação estática que se iniciou na ombreira esquerda da barragem (Morgenstern et al. 2016). 
Os fatores que levaram a ruptura foram muitos, desde dificuldades executivas na construção e operação da barragem até erros conceituais em mudanças do projeto original. Contudo, deve-se destacar a mudança do projeto original, permitindo que condições de saturação pudessem se desenvolver no rejeito arenoso.

A concepção do projeto original empregou uma zona de $200 \mathrm{~m}$ (praia) de rejeito arenoso não saturado como apoio para a zona de lamas. Estudos do histórico de lançamento de rejeitos associados ao alteamento da barragem revelaram que a lama invadiu a zona de deposição dos rejeitos arenosos em diversas ocasiões. A presença da lama criou uma barreira para a drenagem descendente e uma zona de potencial fraqueza que poderia afetar a estabilidade.

Houve também um recuo na ombreira esquerda implementado para acomodar obras de reparo em uma galeria danificada na base do reservatório, bem como para construção de novos tapetes drenantes horizontais, para facilitar o alteamento subsequente do dique. Esta alteração na geometria resultou em um significativo carregamento do aterro sobre depósitos ricos em lama. Isto distingue a área da ombreira esquerda da direita e explica o motivo do local onde a liquefação teve início.

Morgenstern et al. (2016) afirmaram que o mecanismo de gatilho, necessário para dar início a liquefação, foi a extrusão lateral. A medida que a barragem foi sendo alteada as zonas ricas em lama foram carregadas verticalmente e as lamas tenderam a se espalhar lateralmente (extrusão lateral), como acontece quando se aperta um tubo de pasta de dente. Isso resultou em variações no estado de tensões dos rejeitos arenosos sobrejacentes, reduzindo seu confinamento e levando ao colapso. A Figura 2.5 mostra a ruptura. 


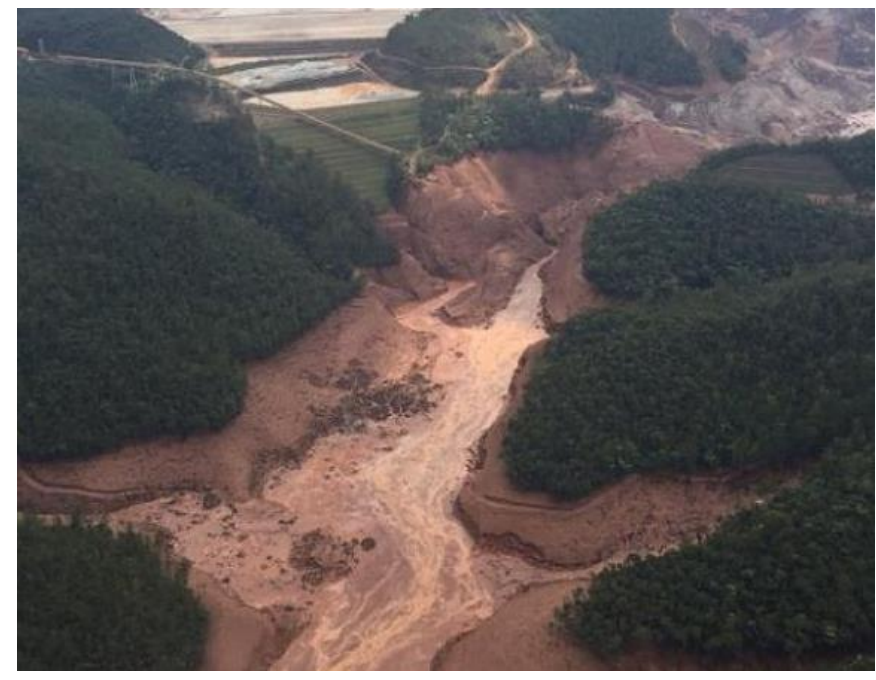

Figura 2.5 - Ruptura da Barragem de Rejeitos de Fundão. (Morgenstern et al, 2016)

\section{2.}

\section{Conceitos Básicos}

\subsection{1.}

\section{Respostas Durante um Carregamento Não Drenado}

Como a liquefação ou fluxo por liquefação ocorre apenas em solos arenosos e no caso muito especifico de argilas com sensibilidade extremamente alta (Lambe e Whitman, 1969), este item se limita em apresentar as respostas típicas de solos arenosos durante o cisalhamento não drenado. A Figura 2.6 apresenta respostas de areias saturadas, submetidas à ensaios triaxiais não drenados com diferentes densidades. As densidades das amostras variam desde densa, passando por medianamente densa, fofa e chegando a muito fofa. 

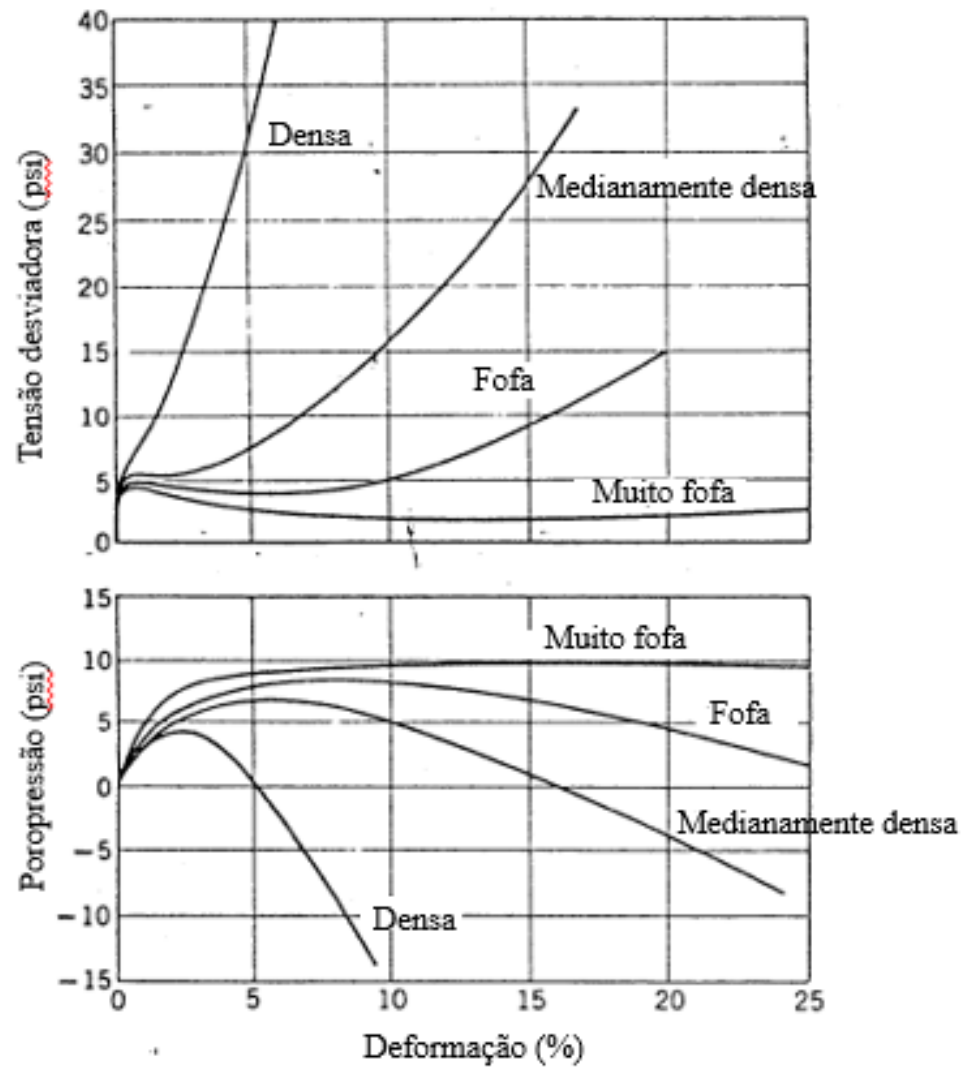

Figura 2.6 - Resultados de ensaios triaxiais não drenados em areia para quatro densidades diferentes. As amostras foram consolidadas para $70 \mathrm{kPa}$. (Adaptado de Healy, 1963)

No caso das amostras densas, os resultados mostram aumento de poropressão nas deformações iniciais (até 2,5\%) e posterior queda. Segundo Casagrande (1935), isso ocorre devido a característica dilatante dos solos densos durante o cisalhamento. A resistência ao cisalhamento, por sua vez, aumenta rapidamente desde o início, mas devido a variação negativa de poropressão, o aumento ocorre sob taxas ainda maiores após o pico de poropressão. Os solos medianamente densos apresentam comportamento semelhante aos solos densos, mas com pico de poropressão bastante suavizado e deslocado para a direita. Inicialmente, a resistência apresenta taxa de crescimento baixa e aumenta após o pico de poropressão.

No caso das areias fofas não se identifica mais um pico de poropressão, mas sim um certo patamar significativo de poropressão, seguido por uma queda bem suavizada. O aumento de poropressão é justificado pela característica contrativa da areia fofa durante parte do cisalhamento e sua queda posterior, pela tendência dilatante adquirida após grandes deformações. A resistência ao cisalhamento aumenta nos instantes iniciais e cai logo depois devido a variação positiva de 
poropressão durante boa parte das deformações. Já a resistência apresenta recuperação após o fim do patamar de poropressão. Yamamuro e Lade (1997) chamaram esse comportamento de liquefação temporária e Ishihara et al. (1980) o nomearam de estado quase permanente.

As areias muito fofas apresentam grande aumento de poropressão seguido por um longo patamar, devido a sua característica contrativa durante todo o cisalhamento. A curva de resistência apresenta o pico máximo com deformações muito pequenas, em torno de 0,25\% (Lambe e Whitman, 1969), seguida de queda até uma condição permanente. Castro (1969), Casagrande (1975) e Seed (1979) chamaram esse comportamento de ruptura por liquefação. Jefferies e Been (2016) chamaram esse comportamento de liquefação verdadeira.

\subsection{2.}

\section{Estado Crítico e Estado Permanente}

Em 1935, Casagrande concluiu que, durante a deformação cisalhante, o volume de areias no estado fofo diminui e o volume de areias no estado denso aumenta, ambos tendendo para uma "densidade crítica" ou "índice de vazios crítico". Casagrande teorizou que este índice de vazios crítico poderia ser encontrado a partir de amostras fofas ou densas (Castro, 1969).

A Figura 2.7 mostra o gráfico de tensão desviadora por deformação axial. Observa-se o comportamento de uma areia compacta e uma areia fofa, notando-se que elas coincidem no mesmo ponto no eixo da tensão desviadora chamado resistência residual. Ao mesmo tempo, projetando esse ponto para o gráfico de tensão desviadora por índice de vazios, tanto para o comportamernto da areia fofa (tendência à contração) como para o da areia compacta (tendencia à dilatação) submetida a carregamentos não drenados, nota-se que o índice de vazios final seria o mesmo para as duas amostras. Esse índice de vazios final é chamado índice de vazios crítico ( $\left.e_{\text {crit }}\right)$. 


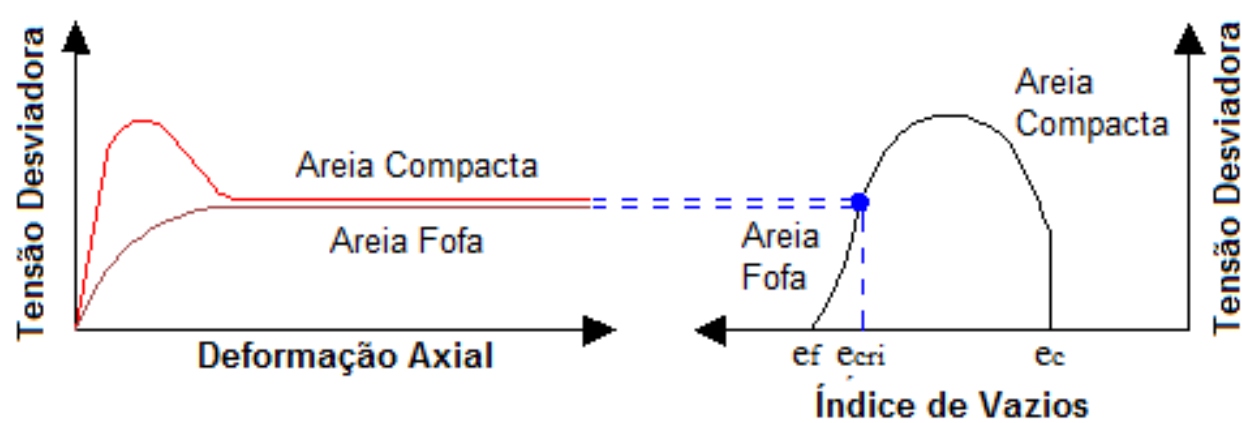

Figura 2.7 - Comportamento de Areias Fofas e Compactas durante o cisalhamento (Adaptado de Washington University, 2008).

A base inicial para o conceito de estado crítico parte da definição de que a densidade de uma amostra afeta o comportamento geotécnico dos solos, podendo ser forte e dilatante, ou fraca e compressível. Para alcançar o índice de vazios crítico, é necessário que ocorram grandes deformações (Castro, 1969).

Após experimentar várias tensões confinantes, Casagrande (1938) concluiu que o índice de vazios crítico diminui com o aumento da tensão confinante. A linha que relaciona o índice de vazio crítico com o logaritmo da tensão confinante efetiva foi definida como "Linha de Estado Crítico", que é a linha limite entre os solos contráteis e dilatantes. (Castro, 1969)

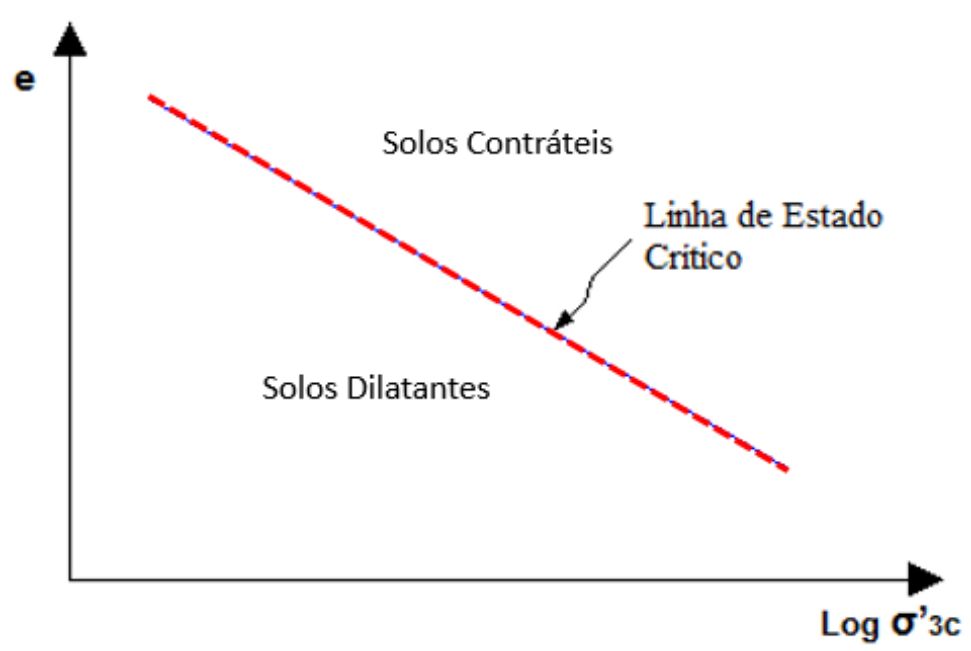

Figura 2.8 - Linha de índice de vazios crítico. (Adaptado de Castro, 1969)

O estado permanente é um método de análise de equilíbrio limite desenvolvido para solos com potencial de liquefação. No coração desse método está o conceito de estado permanente de deformação. (Sladen at al., 1985)

Poulos (1981) afirma que o estado permanente de deformação para qualquer massa de partículas é o estado em que a massa está 
continuamente sofrendo deformação com volume constante, tensão efetiva normal constante, tensão cisalhante constante e velocidade constante. $O$ estado permanente de deformação é alcançado depois que todas as partículas tenham sido orientadas para uma condição de estado permanente e depois que toda partícula tenha sido quebrada, tal que a resistência ao cisalhamento para continuar a deformação e a velocidade de deformação permanecem constantes. A resistência no estado permanente é considerada a mínima possível.

O estado permanente de deformação pode ser considerado como um estado de fluxo plástico em velocidade constante (Sladen et al., 1985).

Como o estado permanente é uma condição de ruptura por cisalhamento, com base no critério de Mohr-Coulomb, segue que as tensões normal e cisalhante no estado permanente são caracterizadas unicamente pelo ângulo de atrito interno no estado permanente; o efeito da coesão no estado permanente é essencialmente zero. As linhas de estado permanente são aproximadamente lineares quando o índice de vazios é plotado contra o logaritmo da tensão (tensão efetiva menor, maior ou tensão cisalhante).

O método de estado permanente para análise de liquefação faz uso da relação única entre resistência ao cisalhamento e índice de vazios no estado permanente. A menor margem de segurança contra perda de resistência devido à liquefação corresponde ao fator de segurança obtido de uma análise de estabilidade convencional onde é atribuído ao solo uma resistência ao cisalhamento não drenado igual a resistência ao cisalhamento no estado permanente para o índice de vazios "in situ". Para aplicar esse método é necessário conhecer sempre a linha de estado permanente do solo e seu índice de vazios "in situ". (Sladen et al., 1985)

Ao longo da história, ensaios de estado permanente foram feitos por tensão controlada (Castro, 1969). O pós-pico, com grande aceleração axial, experimentado por amostras carregadas sob essas condições é uma clara demonstração do efeito potencialmente catastrófico da liquefação em campo. Castro et al. (1982) mostraram que não existe diferença entre resultados de ensaios sob tensão controlada e deformação controlada. Hungr and Morgenstern (1984) e Schimming et al. (1966) mostraram que o comportamento de areias é quase independente da taxa de deformação. Consequentemente, um assunto inerente dessa discussão é que, para fins práticos, o estado "crítico" e "permanente" são considerados um só e o 
mesmo para areias, ou seja, só existe um estado crítico e um estado permanente e eles são o mesmo para as areias.

Jefferies e Been (1991) consideraram que as linhas de estado crítico e permanente são coincidentes e independentes das trajetórias de tensão. Yamamuro e Lade (1997) afirmaram que a maioria dos pesquisadores que estudam o fenômeno de liquefação consideram o estado crítico igual ao estado permanente.

\subsection{3.}

\section{Fluxo por Liquefação e Mobilidade Cíclica}

É importante fazer distinção entre os conceitos de fluxo por liquefação e mobilidade cíclica. Fluxo por liquefação designa o grupo de fenômenos que apresentam em comum o surgimento de altas poropressões em areias saturadas devido a carregamentos estáticos ou ciclicos, sob volume constante. Por outro lado, mobilidade cíclica designa a progressiva deformação de areias dilatantes saturadas quando sujeitas a carregamentos cíclicos sob teor de umidade constante.

Castro e Poulos (1977) apresentaram ensaios triaxiais em amostras de areias saturadas fazendo com que fosse possível um melhor entendimento da diferença entre fluxo por liquefação e mobilidade cíclica. Os resultados desses ensaios estão mostrados na Figura 2.9.

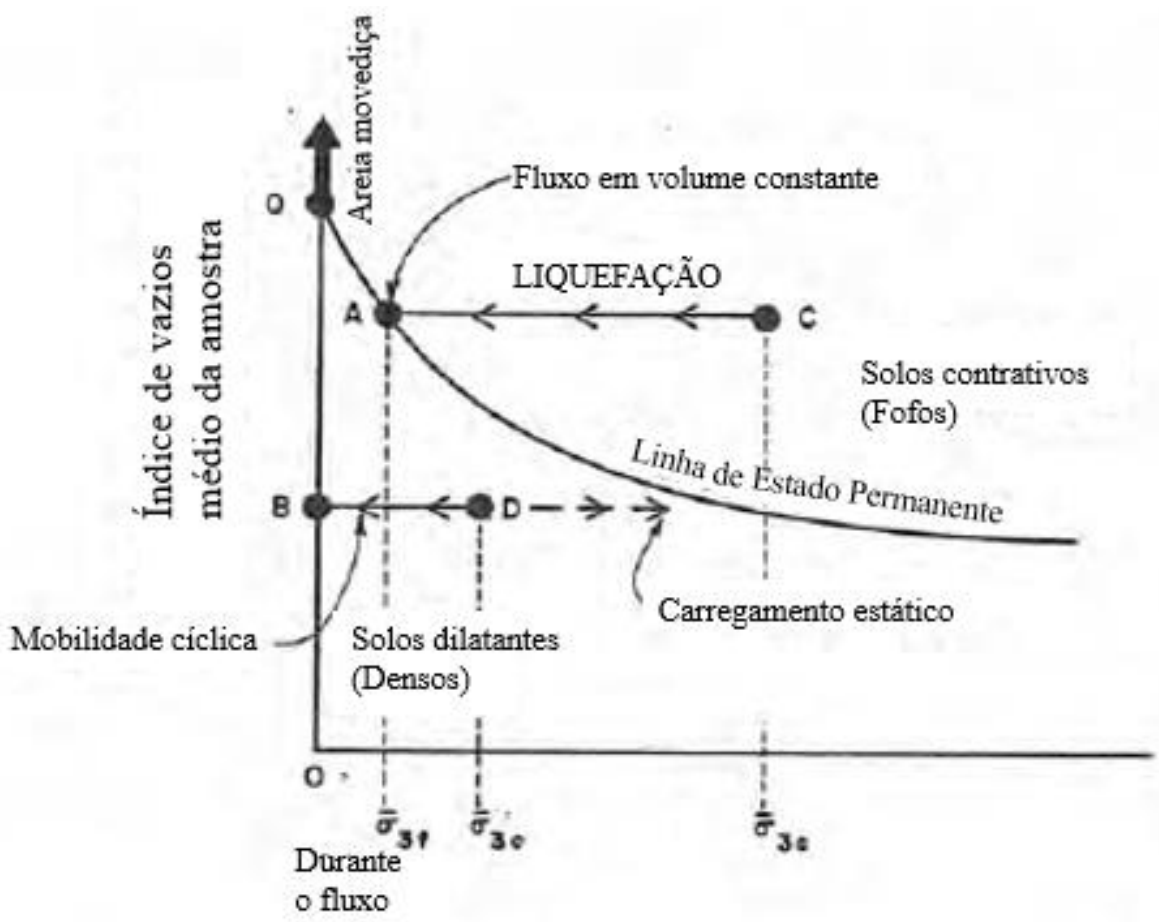

Tensão principal menor efetiva 
Figura 2.9 - Ensaios não drenados em amostras de areia. (Adaptado de Castro e Poulos, 1977)

A linha cheia representa a linha de estado crítico que configura os estados nos quais o solo pode se deformar sob volume e tensões constantes. O ponto $Q$ caracteriza o estado de areia movediça, onde o solo perdeu sua resistencia completamente e não tem tendência de diminuir ou aumentar de volume, pois nessa condição os grãos de areia não estão mais em contato permanente entre si.

$\mathrm{O}$ caminho iniciado no ponto $\mathrm{C}$ e terminado no ponto $\mathrm{A}$ representa o resultado da ruptura não drenada de uma areia contrativa, fenômeno entendido como fluxo por liquefação. Essa ruptura permanecerá sob volume e tensão constante (ponto $A$ ) enquanto continuar o fluxo não drenado.

O ponto D representa uma areia dilatante. Considerando um carregamento estático (monotônico) não drenado nessa areia, temos como resposta uma movimentação horizontal no sentido da linha de estado crítico a medida que ocorre o aumento do carregamento. Por outro lado, caso fosse aplicado um carregamento cíclico não drenado nessa mesma areia (ponto D), haveria uma movimentação horizontal para a esquerda (Mobilidade Cíclica), pois tal carregamento geraria aumento de poropressão. O valor do acréscimo de poropressão dependerá da intensidade do carregamento cíclico, do número de ciclos, do tipo de ensaio entre outros fatores. No processo de mobilidade cíclica, grandes deformações podem ocorrer. Evidências de laboratório mostram que a trajetória DB representa, na verdade, uma condição média com relação a variação do índice de vazios durante o ensaio, ou seja, a trajetória é plotada horizontalmente, pois o índice de vazios médio se mantém constante durante o ensaio.

Portanto, areias saturadas e contrativas (fofas) podem sofrer fluxo por liquefação caso seja aplicado um carregamento estático ou cíclico, não drenado e grande o suficiente para que o acréscimo de poropressão reduza o nível de tensão até o estado permanente. Quanto maior o nível de confinamento $\left(\sigma^{\prime}{ }_{3}\right)$, maiores serão as deformações associadas ao fluxo por liquefação. Caso a areia tenha um índice de vazios acima de $Q$, a resistência após a liquefação (resistência residual) será nula. (Castro e Poulos, 1977) 


\subsection{4.}

\section{O Conceito de Superfície de Colapso}

Sladen et al. (1985) estudaram areias em estado muito fofo e desenvolveram o conceito de superfície de colapso em três dimensões. Para Sladen et al. (1985) a liquefação é um fenômeno onde uma massa de solo perde grande porcentagem de sua resistência ao cisalhamento, quando sujeita à um carregamento estático ou dinâmico, e flui parecendo um líquido, sem resistência ao cisalhamento. Essa definição é praticamente a mesma proposta por Castro et al. (1982), exceto pelo uso do adjetivo não drenado que caracteriza o carregamento, omitido na definição apresentada por Sladen et al. (1985). A omissão do termo não drenado se deve as observações de que até o ponto de ruptura o carregamento pode ser drenado. As características essenciais dessa definição são baixa resistência e perda súbita do equilíbrio limite.

A Figura 2.10 mostra alguns resultados de ensaios triaxiais não drenados executados em três amostras (1, 2 e 3) com o mesmo índice de vazios, mas com tensão de confinamento diferente. Quanto mais alta é a tensão de confinamento inicial, mais alta é a queda no potencial de resistência. Entretanto, a resistência no estado permanente é a mesma para todas as amostras.

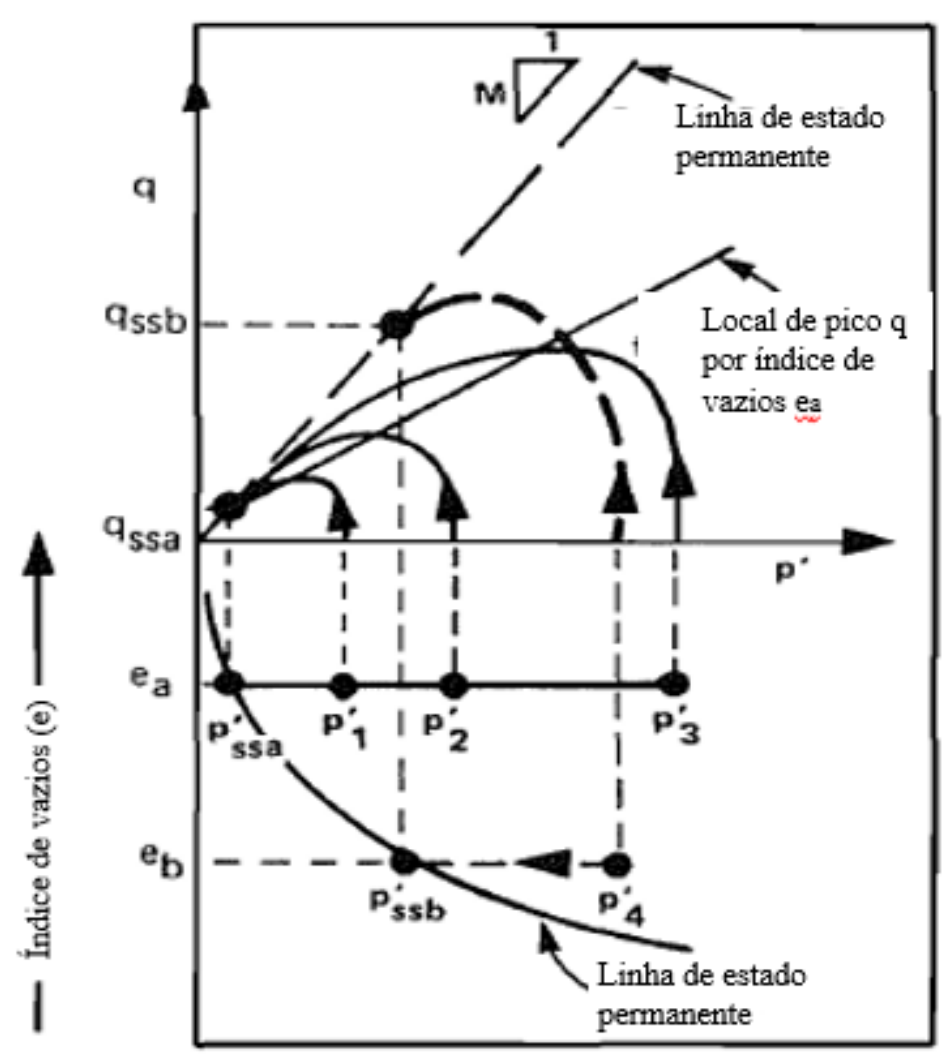

Figura 2.10 - Resultados de ensaios triaxiais não drenados. (Adaptado de Sladen et al., 1985) 
A observação de que o pico de resistência cai em linha reta e que esta linha muda de posição sempre com o índice de vazios deu força ao conceito de superfície de colapso em três dimensões no espaço $(\mathrm{e}-\mathrm{T}-\sigma)$. A superfície de colapso difere dos pontos de pico de uma trajetória de tensões efetivas não drenada. Para ocorrer a liquefação o estado de tensões do solo tem que alcançar a superfície de colapso e a tensão cisalhante deve ultrapassar a resistência ao cisalhamento no estado permanente.

Castro et. al. (1982) mostraram muitos ensaios não drenados sobre areia fofa. Estes ensaios foram normalizados e a Figura 2.11 mostra duas trajetórias de tensão típicas junto com os picos das trajetórias de tensão de outros ensaios sobre a mesma areia.

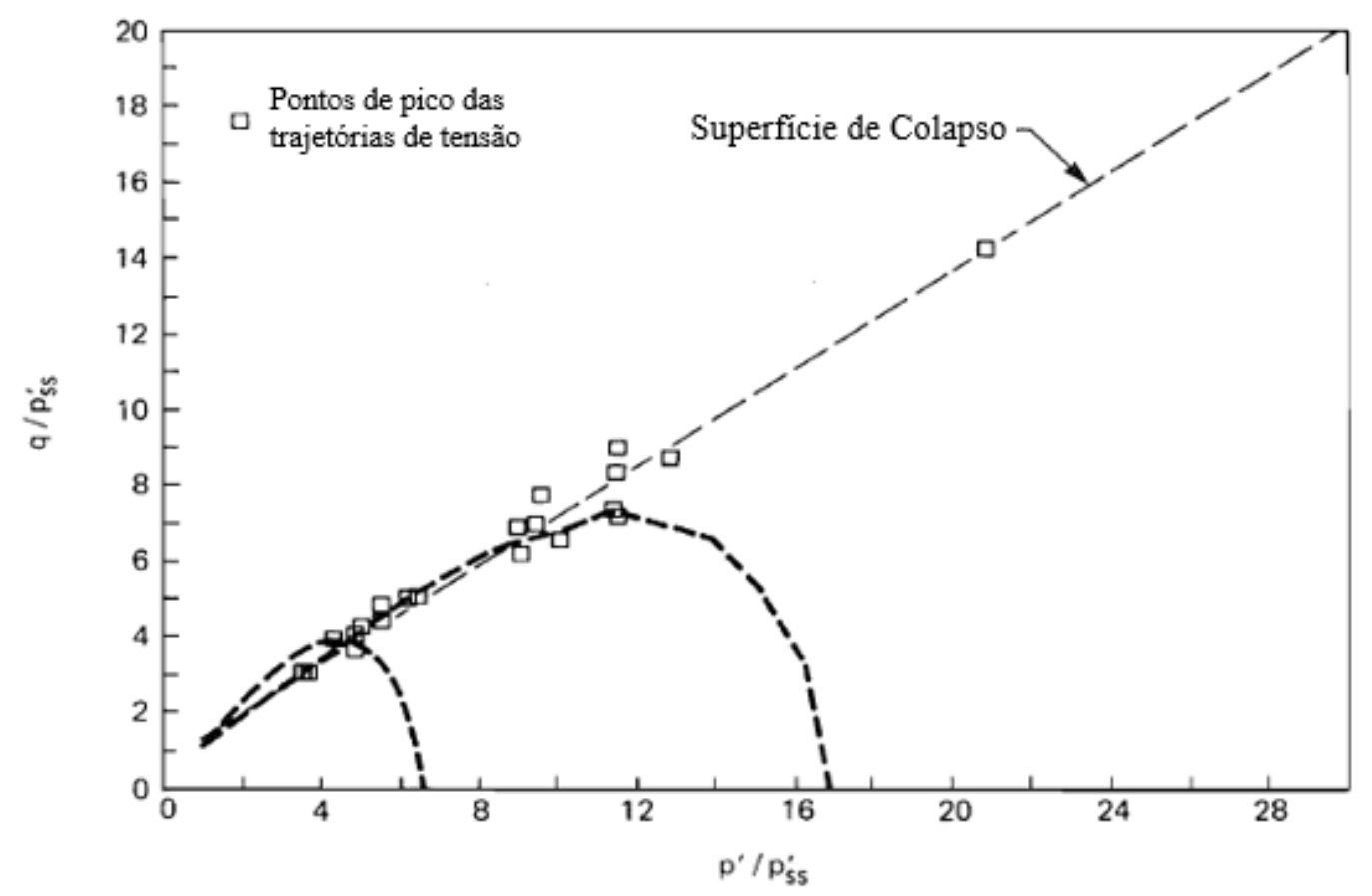

Figura 2.11 - Ensaios triaxiais não drenados sobre areia fofa. (Adaptado de Castro et al., 1982)

No espaço normalizado p'- q estão as mudanças de posição da linha de colapso com a variação do índice de vazios, enquanto a inclinação permanece constante. Com a diminuição do índice de vazios (aumento de densidade) a linha muda para cima e vice-versa. Potencialmente, existem infinitas linhas que num espaço ( $\left.p^{\prime}-q-e\right)$ formam uma superfície (Figura 2.12) que passa através da linha de estado permanente. Seções com volume constante (e constante), através desta superfície, projetam uma série de linhas retas para o espaço p'- q. Areias com estado de tensões próximos ou sobre a superfície iram liquefazer (ou colapsar) quando a drenagem fosse impedida. No caso de carregamento drenado o índice de 
vazios mudaria e a linha de colapso iria se mover para cima para refletir a variação no índice de vazios. (Sladen et al., 1985)

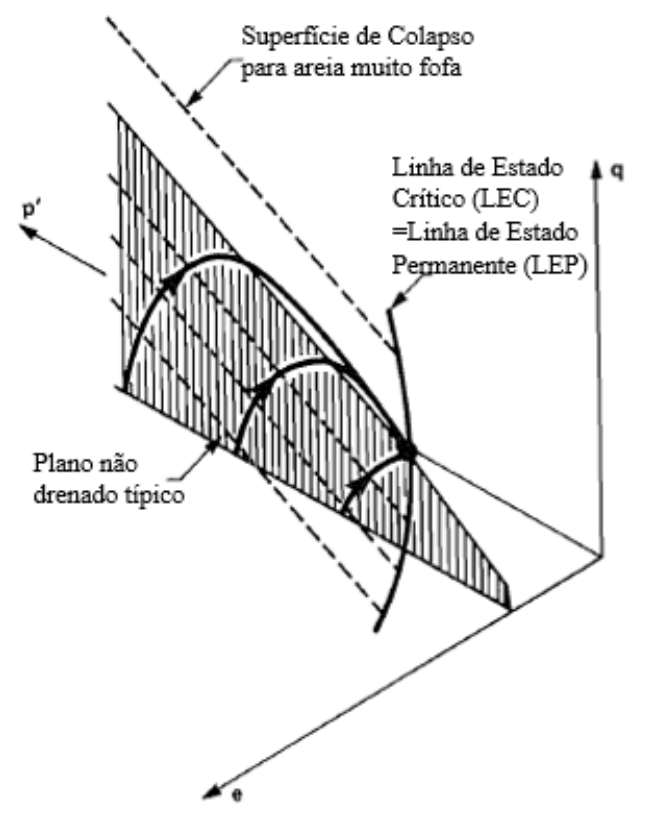

(a)

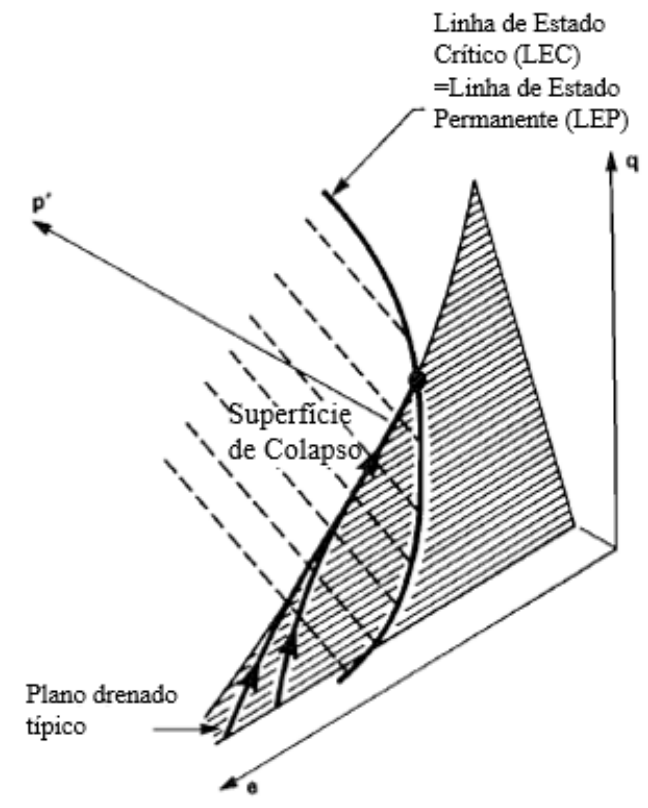

(b)

Figura 2.12 - Superfície de colapso. (Adaptado de Sladen et al., 1985)

\section{- Aplicações para análise de liquefação}

É importante compreender que o método de estado permanente não reivindica a explicação de certas características observadas no fenômeno de liquefação. Primeiro, a ruptura realmente ocorre em níveis de tensão cisalhante muito mais altos do que a resistência ao cisalhamento no estado permanente, como é evidenciado pelos perfis de pós ruptura extremamente planos, que podem ser considerados como indícios de lâminas de fluxo induzidas por liquefação. Segundo, as análises de estabilidade não drenadas preveem incorretamente que os planos de ruptura profundos são mais críticos do que os planos rasos e, portanto, não podem explicar a natureza regressiva observada dos deslizamentos por liquefação, que ocorrem como uma série de rupturas superficiais. Terceiro, nenhum comentário é feito sobre a magnitude da força perturbadora necessária para desencadear o fenômeno da liquefação. Por último, nenhum comentário é feito sobre a influência do estado de tensões "in situ" no potencial de liquefação. (Sladen et al., 1985)

A margem de segurança contra a liquefação para uma determinada geometria e condição de carga é, de acordo com o método de estado permanente, uma função apenas do índice de vazios. Isso é contrário à crença generalizada de que o estado de tensões "in situ" afeta o potencial de liquefação. (Seed, 1979) 
A falha em modelar os aspectos do fenômeno de liquefação não invalida a abordagem de estado permanente como um método de projeto, mas a torna inadequada para a retroanálise das rupturas reais de liquefação. A este respeito, o método de estado permanente é análogo ao uso de parâmetros de resistência residual na análise da estabilidade drenada de taludes de argila. $\mathrm{O}$ uso de parâmetros de resistência residuais poderia ser considerado válido se não houvesse conhecimento sobre o comportamento da resistência de pico ou se houvesse razões para acreditar que a resistência do solo foi reduzida ao seu valor residual na superfície de ruptura considerada (Sladen et al., 1985).

A extensão do modelo de estado permanente para incluir o conceito de superfície de colapso oferece uma explicação para as limitações acima mencionadas.

Adotando algumas simplificações, a superfície de colapso pode ser redefinida em termos dos parâmetros p' e q (Lambe, 1969). No espaço (p' - q) a inclinação da superfície de colapso é designada por $\alpha_{L}$ e o intercepto projetado no eixo q, $a_{L}$, como ilustrado na Figura 2.13. O parâmetro $\alpha_{L}$ é relacionado $\operatorname{com} M_{L}$ pela seguinte equação:

$M_{L}=\frac{6 \tan \alpha_{L}}{3-\tan \alpha_{L}}$

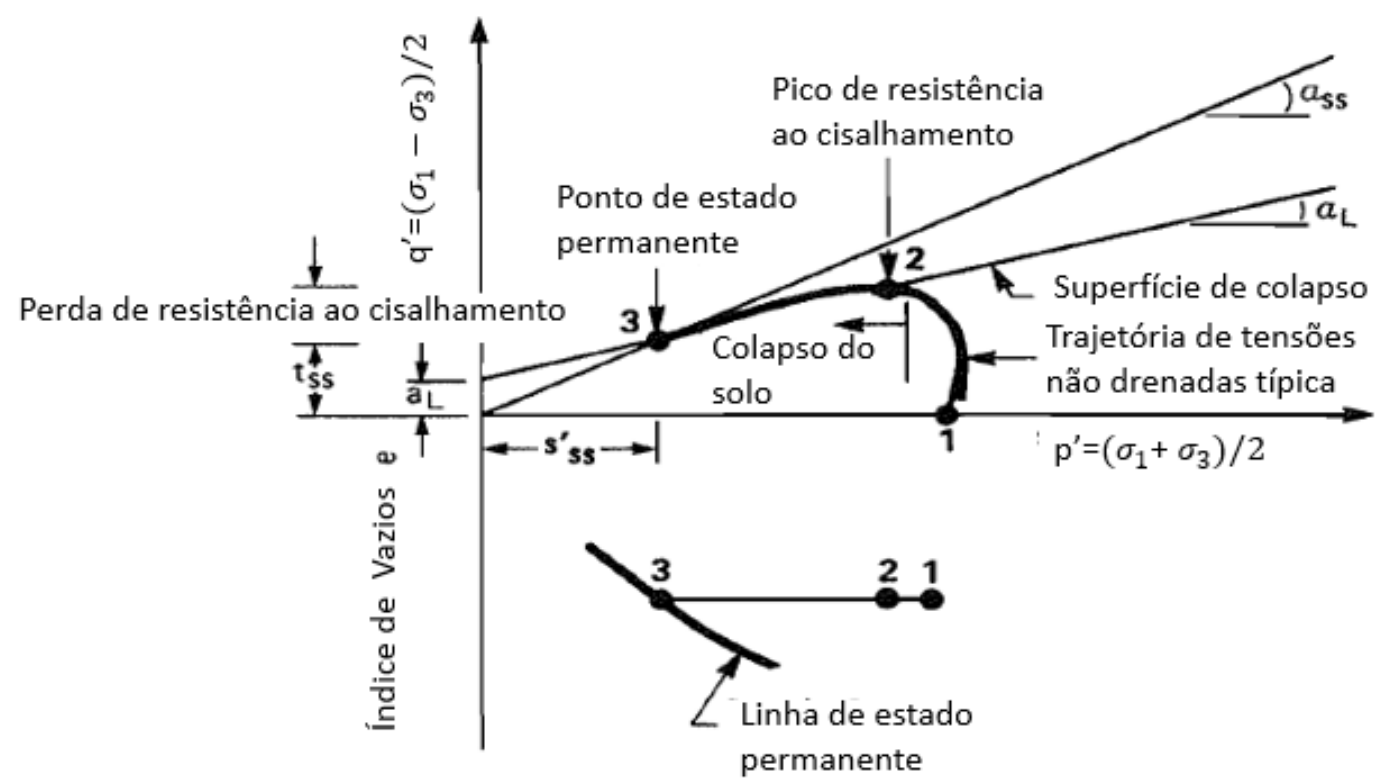

Figura 2.13 - Superfície de colapso no espaço p' - q. (Adaptado de Sladen et al., 1985) 
A superfície de colapso pode ser definida neste espaço por parâmetros análogos aqueles usados na definição das condições de ruptura de Mohr-Coulomb. Podemos imaginar a superfície de colapso como definida inicialmente por um ângulo de atrito interno equivalente $\emptyset_{L}$ e um intercepto coesivo equivalente $c_{L}$, onde:

$\sin \emptyset_{L}=\tan \alpha_{L} ; c_{L}=\frac{\alpha_{L}}{\cos } \emptyset_{L}$

\section{3.}

\section{Características e Condições que Influenciam a Liquefação}

As características e condições que influenciam a liquefação são várias. Neste item serão abordadas algumas dessas características e condições, tais como granulometria, teor de finos, forma dos grãos, composição mineralógica, condições de saturação, velocidade de carregamento, tensão de confinamento e densidade relativa.

Em condições não drenadas o excesso de poropressão gerado por carregamentos cíclicos e estáticos em solos arenosos fofos pode reduzir a tensão efetiva a zero. Neste caso, os contatos entre partículas deixam de existir, as partículas ficam em suspensão e o solo se comporta como um líquido viscoso. Este estado de fluidez é denominado fluxo por liquefação (Ishihara, 1993).

O fenômeno de liquefação estática está diretamente relacionado a solos arenosos, contrativos, saturados e submetidos a carregamentos não drenados, apresentando redução considerável da resistência ao cisalhamento devido ao acréscimo das poropressões (Jefferies e Been, 2016).

\subsection{1.}

\section{Influência da Granulometria e Teor de Finos}

A distribuição granulométrica é um fator importante na avaliação da susceptibilidade à liquefação. De acordo com Kramer (1996) solos bem graduados são geralmente menos suscetíveis à liquefação do que aqueles com graduação uniforme, pois o preenchimento dos vazios formados entre as partículas de tamanhos diferentes gera uma alteração do volume em condições drenadas e menor excesso de poropressão em condições não drenadas. 
Bray et al. (2004) observaram que não é a quantidade de partículas com granulometria fina que melhor indica a suscetibilidade de um solo à liquefação, mas sim a quantidade de argilo-minerais. Assim, o índice de plasticidade (IP) do solo seria o melhor indicador da suscetibilidade à liquefação (Carraro et al., 2003). Boulanger e Idriss $(2004,2006)$ utilizam o índice de plasticidade para a diferenciação entre solos com comportamento de areia e argila. Estes pesquisadores concluíram que os solos com IP maior que $7 \%$ podem ser classificados como não suscetíveis à liquefação por apresentarem comportamento de argila.

Com relação a presença de siltes, Ishihara (1993) atribuiu grande resistência à liquefação a areias contendo siltes plásticos devido a coesão dos finos presentes. Dois anos mais tarde o mesmo autor observou que rejeitos areno-siltosos são suscetíveis à liquefação devido à natureza não plástica dos finos.

De acordo com a Figura 2.14(b), depósitos de solo natural com D50 menor do que $0.02 \mathrm{~mm}$ ou maior do que $2 \mathrm{~mm}$ não são suscetíveis à liquefação, assim também a Figura 2.14(a) apresenta uma faixa granulométrica para os rejeitos de granulometria fina com suscetibilidade à liquefação (Terzaghi et al., 1996). Por outro lado, de acordo com Terzaghi et al. (1996), rejeitos de mineração são altamente suscetíveis à liquefação, embora contenham uma significativa quantidade de partículas com tamanho de silte e argila, uma vez que estes finos são compostos de sólidos não plásticos. 


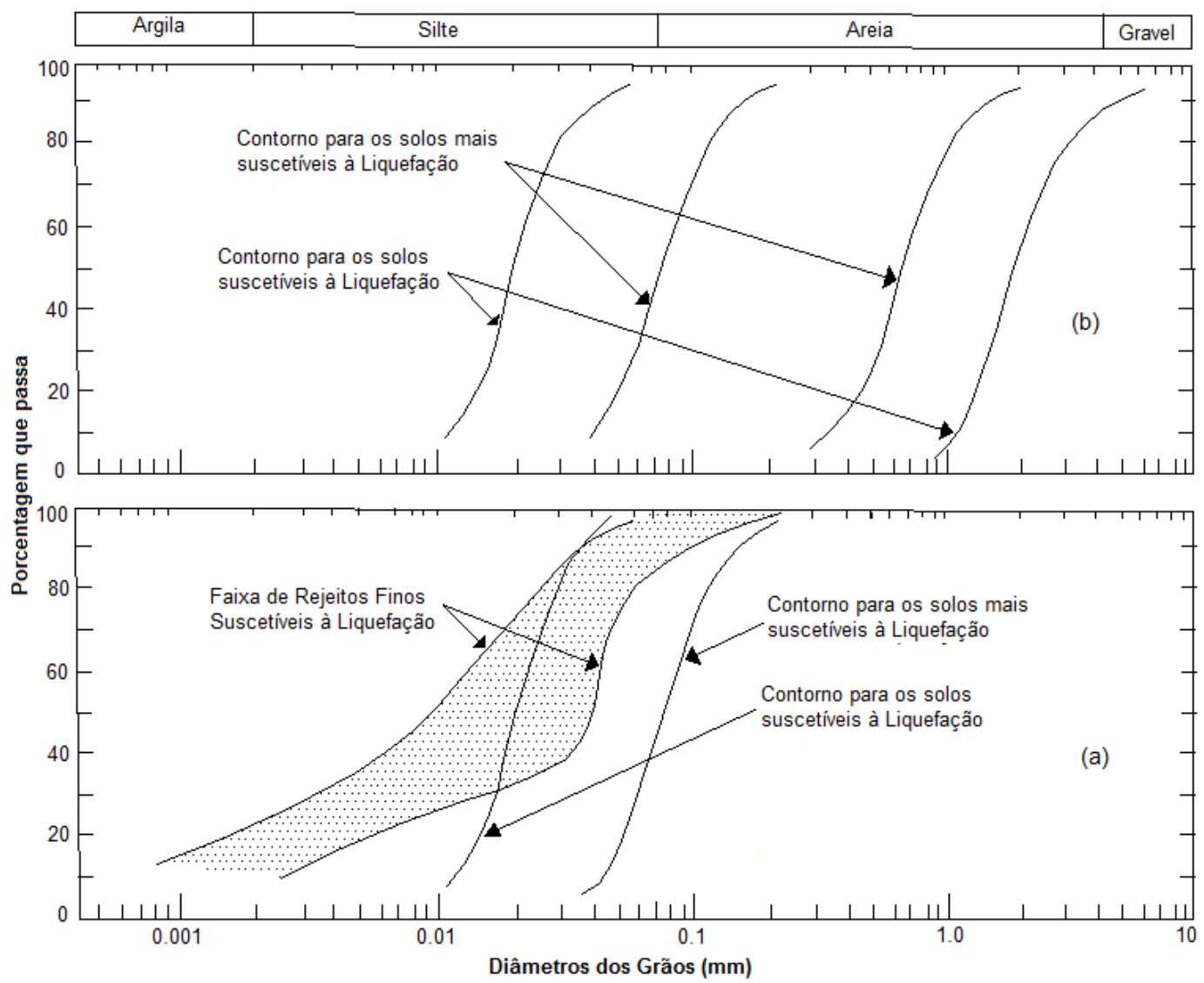

Figura 2.14 - Limites Granulométricos de Suscetibilidade à Liquefação (Adaptado de Terzaghi et al., 1996)

Ishihara et al. (1980) também apresentam limites granulométricos em que um determinado solo granular pode ser classificado com maior ou menor suscetibilidade à liquefação. A Figura 2.15 apresenta esses limites.

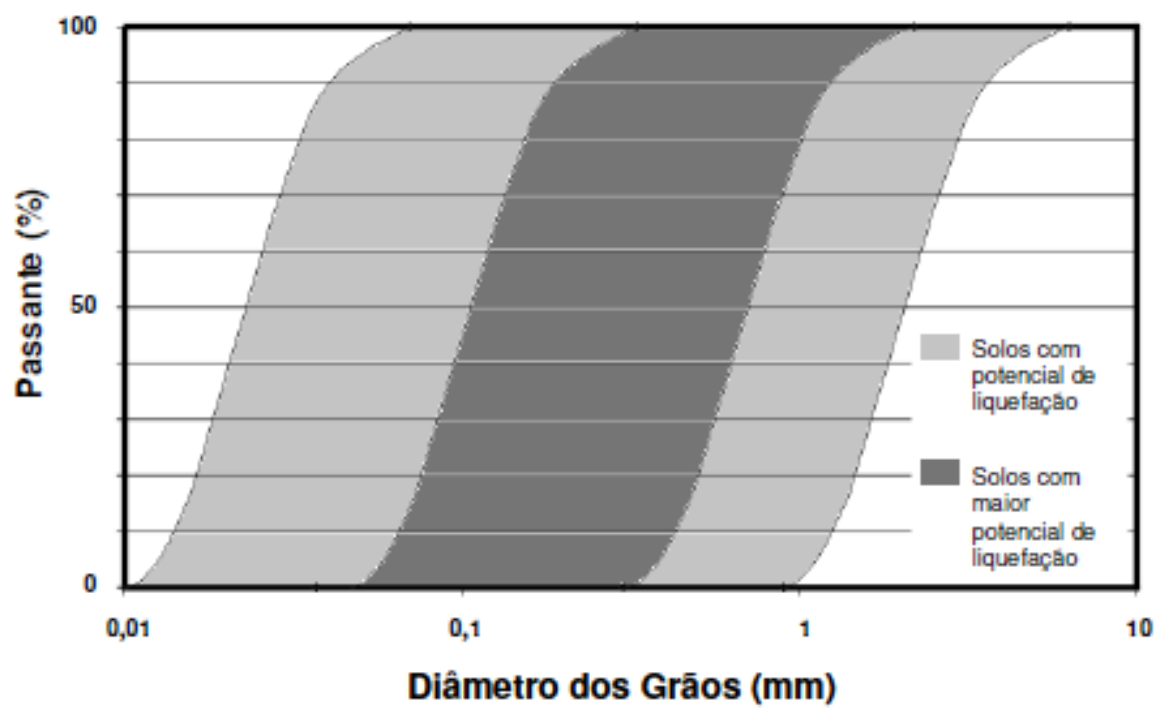

Figura 2.15 - Limites granulométricos dos materiais suscetíveis à liquefação proposto por Ishihara et al (1980). (Pereira, 2005) 


\subsection{2.}

\section{Influência da Forma dos Grãos}

O formato das partículas tem também uma influência na suscetibilidade à liquefação. Solos com partículas arredondadas apresentam menos embricamento do que aqueles com partículas de formato angular (Sayão, 2016). A força de atrito entre grãos angulares é maior devido ao melhor entrosamento, conseguindo uma maior resistência ao cisalhamento. Consequentemente, apresentam maior resistência à liquefação.

\subsection{3.}

\section{Influência da Composição mineralógica}

As propriedades químicas e mineralógicas dos rejeitos de mineração e solos naturais são dependentes principalmente da composição da rocha de origem e do intemperismo em que essa rocha foi submetida. Estas propriedades, por sua vez, exercem influência no comportamento mecânico e hidráulico dos materiais arenosos (Pereira, 2005).

Pereira (2005) afirma que em análises específicas de rejeitos de minério de ferro sob carregamento não drenado, observou-se que a composição mineralógica pode representar um fator fundamental relacionado à liquefação. Quando ocorre a oxidação do ferro presente no rejeito, algumas texturas são geradas e podem influenciar a resistência ao cisalhamento. Portanto, o teor de ferro dos rejeitos arenosos quando oxidados pode influenciar, de forma direta, a suscetibilidade à liquefação.

\subsection{4.}

\section{Influência da Saturação}

A liquefação pode ocorrer mesmo em condições de solos não saturados, mas que apresentem um grau de saturação suficiente para que a contração resulte em expulsão de água ao invés de ar (Aubertin et al., 2003). Ensaios de laboratório têm confirmado a possibilidade de ocorrência da liquefação em matérias com grau de saturação da ordem de $80 \%$. (Martín, 1999)

As condições necessárias para determinar se o carregamento de um solo com alto grau de saturação será drenado ou não drenado são os coeficientes de permeabilidade do solo e a velocidade do carregamento. (Pimenta, 2009) 


\subsection{5.}

\section{Influência da Permeabilidade}

A condutividade hidráulica dos solos arenosos está fortemente ligada à distribuição granulométrica e é influenciada pela porcentagem de finos no material. A presença de finos no solo representa um fator de grande influência na magnitude da condutividade hidráulica. Portanto, um maior teor de finos implica em uma redução significativa no valor da condutividade hidráulica do solo, pois tal fato gera redução da área da seção transversal dos poros de escoamento (Pereira, 2005).

Formulações empíricas com base nos parâmetros de granulometria, grau de esfericidade, natureza do arranjo estrutural e o diâmetro do poro percolado foram estabelecidas para solos arenosos uniformes. A formulação de Hazen é uma delas:

$k=C \cdot D^{2}{ }_{e f}$

Onde $\mathrm{k}$ é o coeficiente de permeabilidade, C é uma constante de permeabilidade que considera algumas propriedades do meio poroso (90< $C<120$ ) e o Def é diâmetro efetivo (D10) do material (Hazen, 1948).

Utilizando-se da formulação de Hazen, pode ser definida uma faixa aproximada de variação da permeabilidade dos solos arenosos suscetíveis à liquefação, a partir dos limites granulométricos propostos por Ishihara et al. (1980). Para um valor da constante $C$ igual a 100, os materiais definidos por Ishihara et al. (1980) como suscetíveis à liquefação estariam situados em uma faixa aproximada de permeabilidade variando entre 0,0001 e 1 $\mathrm{cm} / \mathrm{s}$. Deve-se levar em consideração o empirismo da relação, quando destacado o grau de uniformidade do solo e, no caso de rejeitos, a sua composição mineralógica (Pereira, 2005).

Assim, os materiais arenosos e finos seriam mais propensos a entrar em liquefação quando comparados aos materiais de granulometria mais grosseiras. Este fato está ligado à maior condutividade hidráulica dos materiais grosseiros, associada a uma dissipação rápida das poropressões (Pereira, 2005). 
2.3.6.

\section{Liquefação em Depósitos Naturais}

Sedimentos naturais areno-siltosos tendem a ser depositados em estado fofo e, portanto, são mais propensos a apresentar um comportamento de cisalhamento contrativo do que as areias limpas. (Poulos et al., 1985)

Depósitos de areias contendo siltes plásticos apresentam uma elevada resistência à liquefação devido à coesão dos finos existentes (Ishihara, 1993).

Para solos naturais, o teor de finos tem influência considerável na suscetibilidade à liquefação, pois a presença de finos plásticos contribui para a redução da condutividade hidráulica do solo, dificultando o acréscimo de poropressões, assim como também, contribui para o aumento da resistência ao cisalhamento, devido ao acréscimo da coesão. A interação dos grãos possui uma estrutura mais compacta. Para solos formados por finos com baixa plasticidade, a influência não é considerável, devido ao aumento da suscetibilidade à liquefação causada pela redução da condutividade hidráulica (Ishihara, 1993).

\subsection{7. \\ Influência da Velocidade de Carregamento}

Em solos arenosos, a influência da velocidade de carregamento é grande quando ocorre cisalhamento drenado. No caso de cisalhamento não drenado esta influência é pequena (Pereira, 2005).

Yamamuro e Lade (1993), mostraram que um aumento na velocidade de carregamento de solos arenosos gera poropressões mais altas. Essa diferença de poropressão é explicada pelo rearranjo dos grãos durante o cisalhamento. Tibana et al. (1998) constataram um efeito inverso, ou seja, para velocidades de carregamento mais altas, se observou geração de poropressão menor e velocidades mais baixas geraram poropressões maiores.

Head (1998) define a velocidade de carregamento com base no adensamento primário dos solos arenosos. Pereira (2005) mostra que esse método resulta em velocidades de carregamento razoáveis para o registro das poropressões. A Figura 2.16 mostra que para o intervalo de velocidade de $0,04 \mathrm{~mm} / \mathrm{s}-0,09 \mathrm{~mm} / \mathrm{s}$, a geração de poropressão é quase a mesma. 


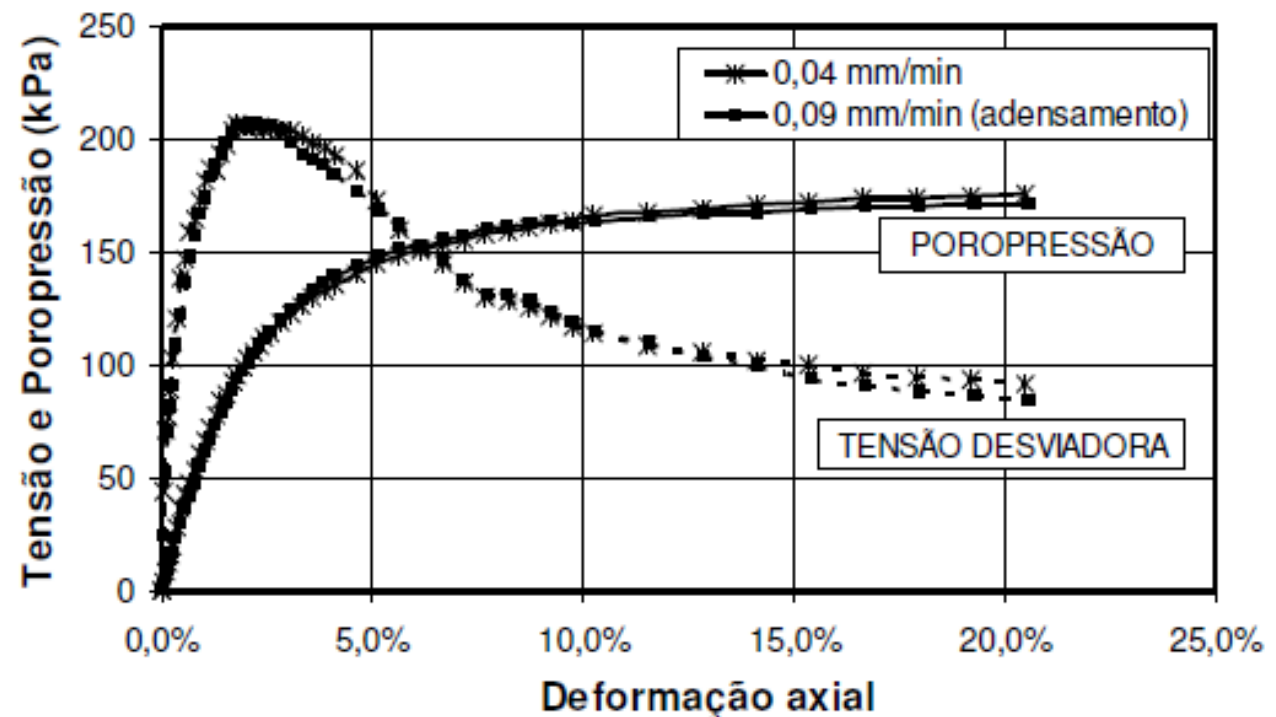

Figura 2.16- Resultados de tipo CIU em amostras de minério de ferro sob velocidade de carregamento diferentes. (Pereira, 2005)

\subsection{8.}

\section{Influência da Tensão de Confinamento}

Lee (1965), Seed e Lee (1967), Vaid and Chern (1985), Ishihara (1993) e outros mostraram que areias fofas são caracterizadas pela dilatação em baixas tensões de confinamento. Contudo, a medida em que ocorre o aumento da tensão confinante, ocorre uma tendência de comportamento contrativo. Esse tipo de comportamento é definido como comportamento de solo normal. As Figuras 2.17 e 2.18 mostram ensaios não drenados sobre a areia do rio de Sacramento indicando comportamento normal.

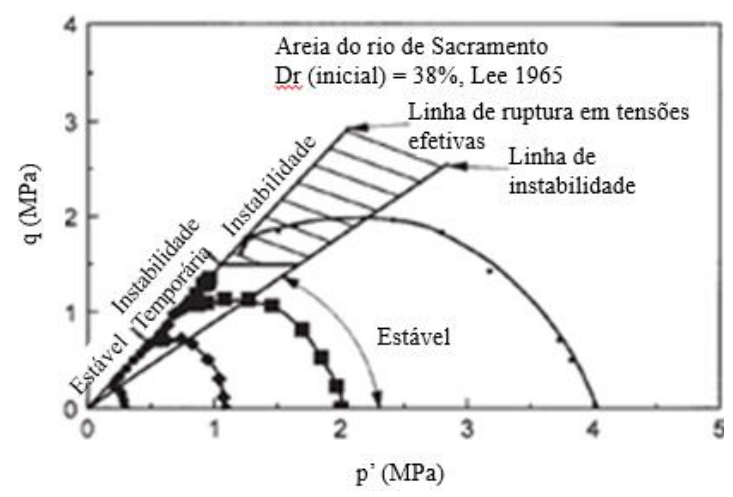

Figura 2.17 - Trajetórias de tensões efetivas. (Adaptado de Lee, 1965)

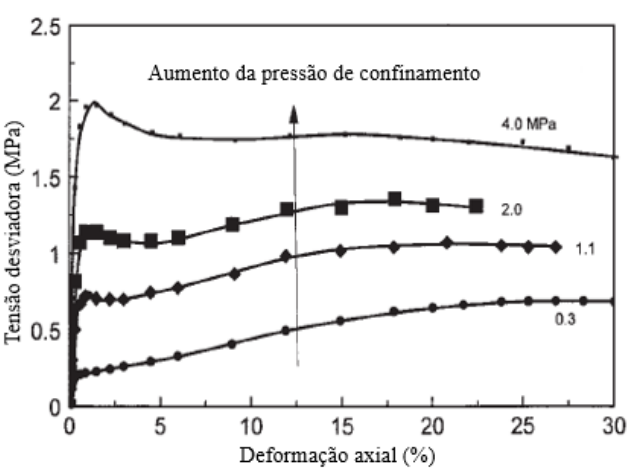

Figura 2.18 - Tensão de desviadora vs. deformação axial. (Adaptado de Lee, 1965)

Em 1997, Yamamuro e Lade observaram um comportamento diferente para as areias de Nevada e Ottawa. As Figuras 2.19 e 2.20 mostram que houve liquefação completa em quatro ensaios executados (tensão de conf. $=25,75,100$ e $125 \mathrm{kPa}$ ). Para esses ensaios, a tensão 
desviadora cai a zero após o pico de resistência e se mantem assim para grandes deformações.

As curvas tensão-deformação dos ensaios com tensão de confinamento iguais à 150, 300 e 500kPa ("tensões altas") mostram que, ao contrário dos ensaios com baixa tensão de confinamento, ocorre um pico inicial de resistência seguido por uma queda até um valor mínimo (isso ocorre pela rápida geração de excesso de poropressão, levando a queda de resistência). Imediatamente após o ponto mínimo ocorre ganho de resistência superando o pico inicial, condição chamada de liquefação temporária. Isso se deve à tendência dilatante da amostra que diminui o excesso de poropressão, resultando em aumento de tensão efetiva.

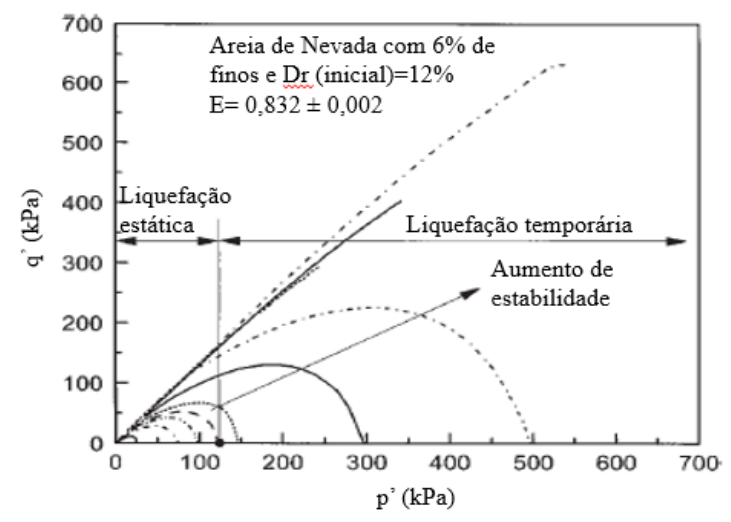

Figura 2.19 - Trajetórias de tensões efetivas para a areia de Nevada. (Adaptado de Yamamuro e Lade, 1997)

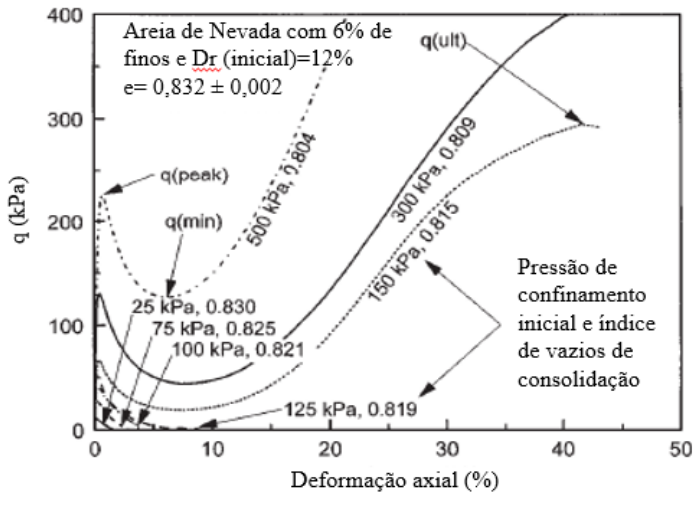

Figura 2.20 - Curvas tensão deformação para a areia de Nevada. (Adaptado de Yamamuro e Lade, 1997)

Yamamuro e Lade (1997) concluíram então que grandes tensões de confinamento podem aumentar a resistência contra a liquefação de areias fofas devido a dois fatores. Primeiro, o efeito do aumento da tensão confinante durante compressão isotrópica densifica bastante areias muito fofas, criando um solo mais dilatante. As areias diminuem seu coeficiente de compressibilidade (av) com o aumento da tensão de confinante (Figura 2.21). Solos muito compressíveis indicam baixa rigidez do esqueleto sólido. Contudo, quando a tensão de confinamento é aumentada, a compressibilidade diminui rapidamente e, quando associada a uma densificação, aumenta a tendência dilatante durante o cisalhamento. 


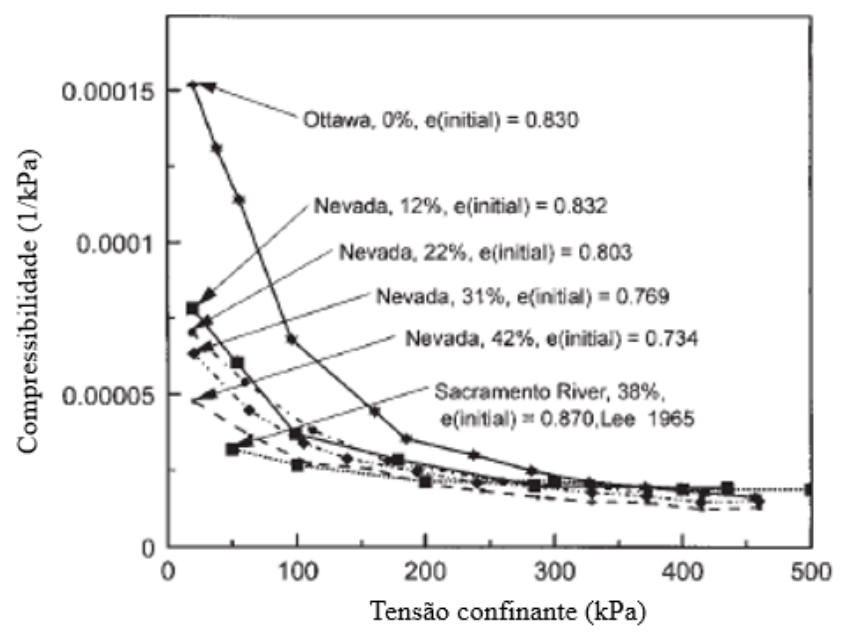

Figura 2.21 - Ensaios de compressão isotrópica sobre as areias de Nevada,

Ottawa e Sacramento em diferentes densidades iniciais.

A areia do rio de Sacramento apresentou uma curva de compressibilidade quase plana, mostrando que é relativamente insensível aos efeitos do aumento da tensão de confinamento. Essa compressibilidade relativamente constante é característica de um solo normal. A curva de compressibilidade das areias de Nevada e Ottawa cortam a curva de compressibilidade da areia do rio de Sacramento e continuam a descer. Isso mostra que o efeito do aumento da dilatância continua crescendo para altas tensões.

A segunda razão pela qual a resistência contra a liquefação de areias fofas pode aumentar com o aumento da tensão confinante é que em ensaios com altas tensões de confinamento existe, simplesmente, mais confinamento para absorver a poropressão gerada antes de ocorrer a liquefação estática (Yamamuro e Lade, 1997).

\subsection{9.}

\section{Influência da Densidade Relativa}

Yamamuro e Lade (1997) observaram que quanto maior a densidade relativa, menor o alcance da liquefação. As Figuras 2.22 e 2.23 mostram que as trajetórias de tensões para duas densidades iniciais distintas (22\% e 31\%). Observou-se liquefação total na areia com densidade relativa igual a $22 \%$ para um confinamento de $25 \mathrm{kPa}$, enquanto que para a areia com $31 \%$ de densidade relativa foi observado apenas a liquefação temporária. Resultados dessa mesma areia, com densidade relativa de $12 \%$, apresentam liquefação total para tensões de confinamento de até $125 \mathrm{kPa}$. 


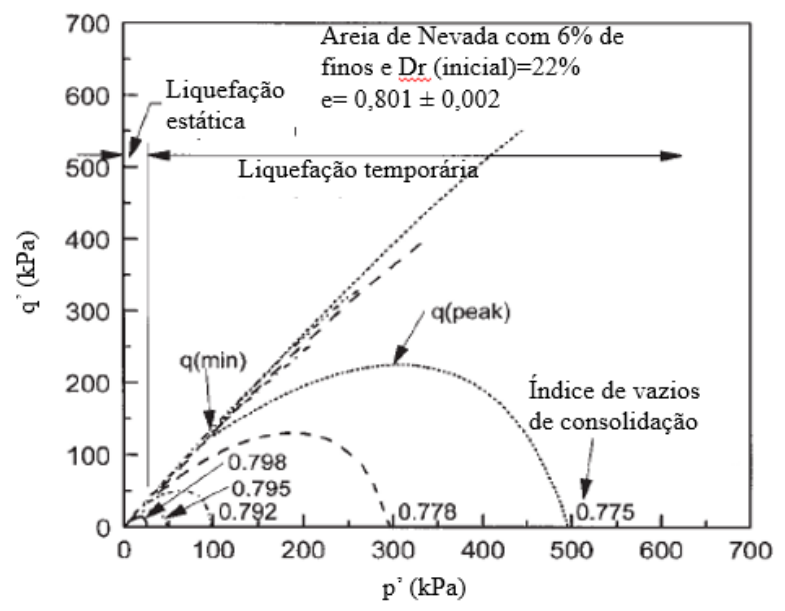

Figura 2.22 - Trajetória de tensões efetivas para areia de Nevada com $\mathrm{Dr}=22 \%$.

(Adaptado de Yamamuro e Lade, 1997)

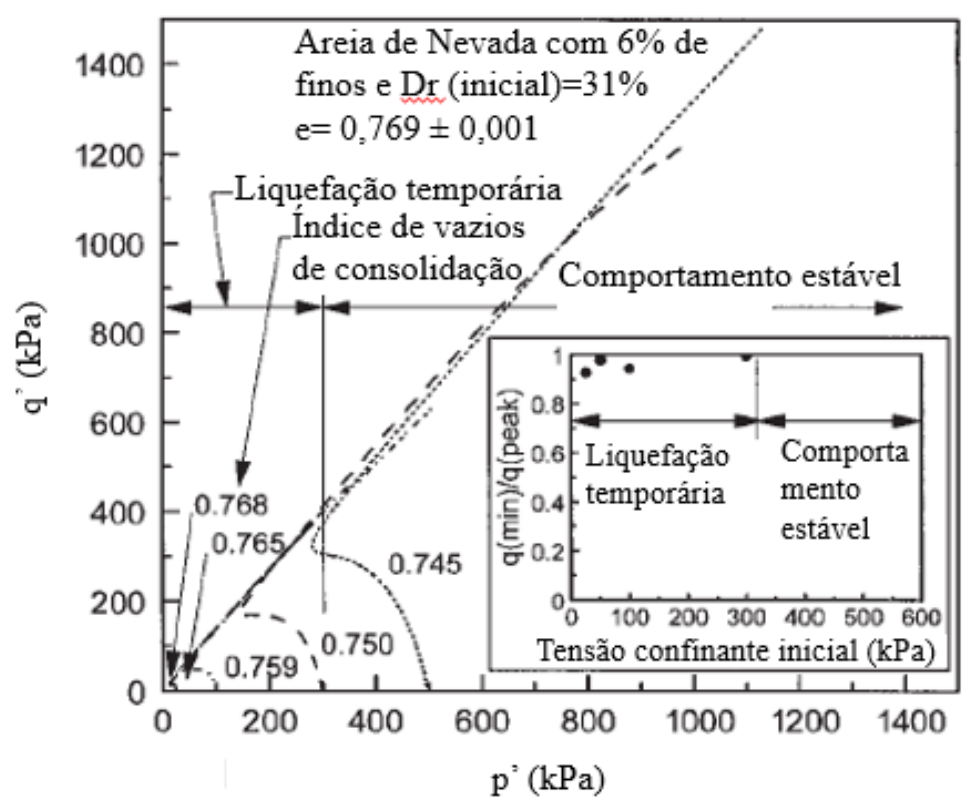

Figura 2.23 - Trajetória de tensões efetivas para areia de Nevada com $\mathrm{Dr}=31 \%$.

(Adaptado de Yamamuro e Lade, 1997) 


\section{3 \\ Programa Experimental}

O programa experimental executado foi concentrado na caracterização geotécnica das amostras e no comportamento tensão deformação desses materiais sob condições não drenadas. Este capítulo apresenta os resultados obtidos, assim como os métodos utilizados para tais observações.

Duas amostras foram estudas: a primeira é oriunda do bairro de Camboinhas, região oceânica de Niterói, localizada no estado do Rio de Janeiro, e consiste em uma areia de praia limpa transportada hidraulicamente para servir de sobrecarga em um aterro sobre solo mole; A segunda é oriunda do município de Mariana, localizado no estado de Minas Gerais, e consiste em um rejeito arenoso originada do beneficiamento de minério de ferro.

\section{1.}

\section{Caracterização Geotécnica das Amostras}

Para fins de caracterização geotécnica, o presente trabalho limitou-se a determinar a massa especifica dos grãos, a distribuição granulométrica, os índices de vazios máximo e mínimo e a forma dos grãos das duas amostras estudadas.

\subsection{1.}

\section{Determinação da Massa Específica dos Grãos (Ys)}

A massa específica dos grãos das duas amostras estudadas foi determinada conforme o procedimento interno do laboratório de geotecnia da PUC-Rio, tendo como base a NBR 6508/84. A Tabela 3.1 apresenta os resultados encontrados. 
A amostra de Camboinhas apresentou um valor de ys típico de areias quartzosas da região costeira do estado do Rio de Janeiro. Ratton (1993) apresenta valores bem próximos $\left(2,677 \mathrm{~g} / \mathrm{cm}^{3}\right)$ para a areia de Ipanema, $R J$.

A amostra de Mariana apresentou um valor alto de $\mathrm{ys}$ devido à presença de ferro remanescente do processo de mineração. Rezende (2013) mostra que a porcentagem média de ferro contida em rejeitos arenosos da mesma região é de 17,34\%.

Tabela 3.1- Massa específica dos grãos das amostras estudadas.

\begin{tabular}{ccc}
\hline Amostra & $\begin{array}{c}\gamma s \\
\left(\mathrm{~g} / \mathrm{cm}^{3}\right)\end{array}$ & Des vio Padrão \\
\hline \hline Mariana & 2,918 & 0,002 \\
Camboinhas & 2,679 & 0,01 \\
\hline
\end{tabular}

\subsection{2.}

\section{Distribuição Granulométrica das Amostras}

A distribuição granulométrica das amostras estudadas foi determinada conforme o procedimento interno do laboratório de geotecnia da PUC-Rio, tendo como base a NBR 7181/84. As Figuras 3.1 e 3.2 mostram as curvas granulométricas obtidas para as amostras. Além disso, foi inserido o critério de Ishihara et al. (1980) para estimar a suscetibilidade à liquefação desses materiais.

Rejeito arenoso de Mariana

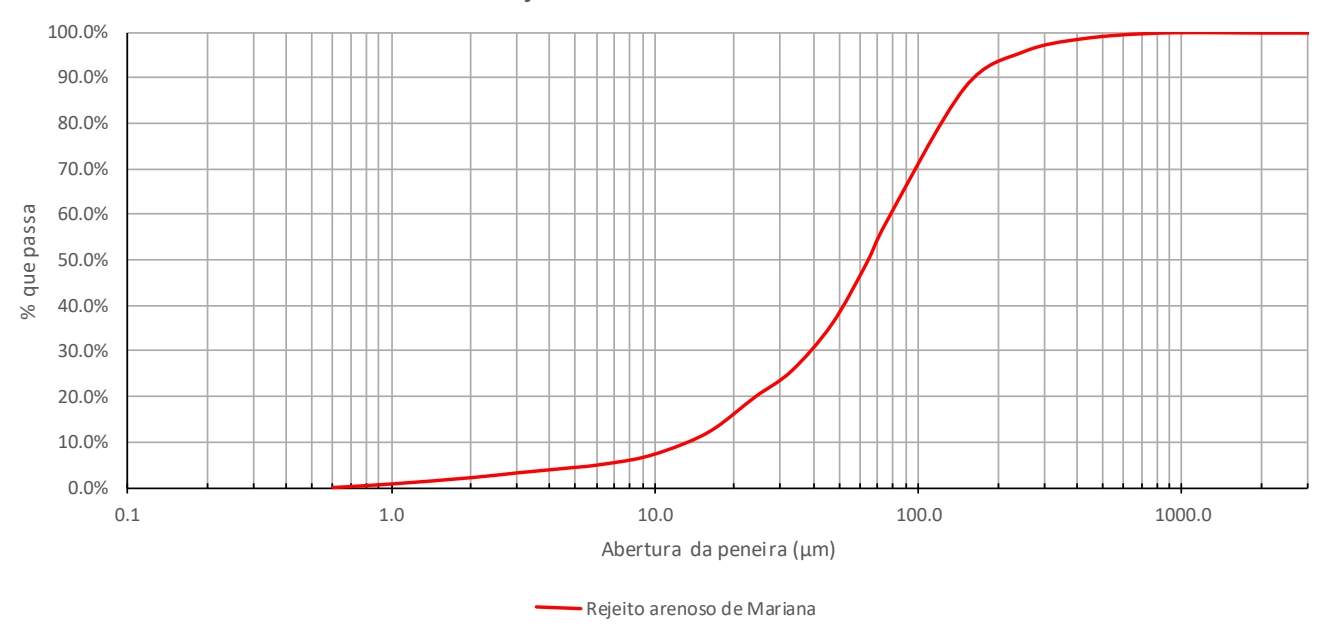

Figura 3.1 - Curva granulométrica da amostra de Mariana. 
Tabela 3.2 - Percentual da amostra de Mariana.

\begin{tabular}{|c|c|}
\hline Materiais & Porcentagem \\
\hline Areia Grossa & $0.0 \%$ \\
\hline Areia Média & $4.2 \%$ \\
\hline Areia Fina & $46.2 \%$ \\
\hline Silte Grosso & $29.7 \%$ \\
\hline Silte Médio & $15.0 \%$ \\
\hline Silte Fino & $2.8 \%$ \\
\hline Argila Grossa & $2.2 \%$ \\
\hline Argila Média & $0.0 \%$ \\
\hline Argila Fina & $0.0 \%$ \\
\hline
\end{tabular}

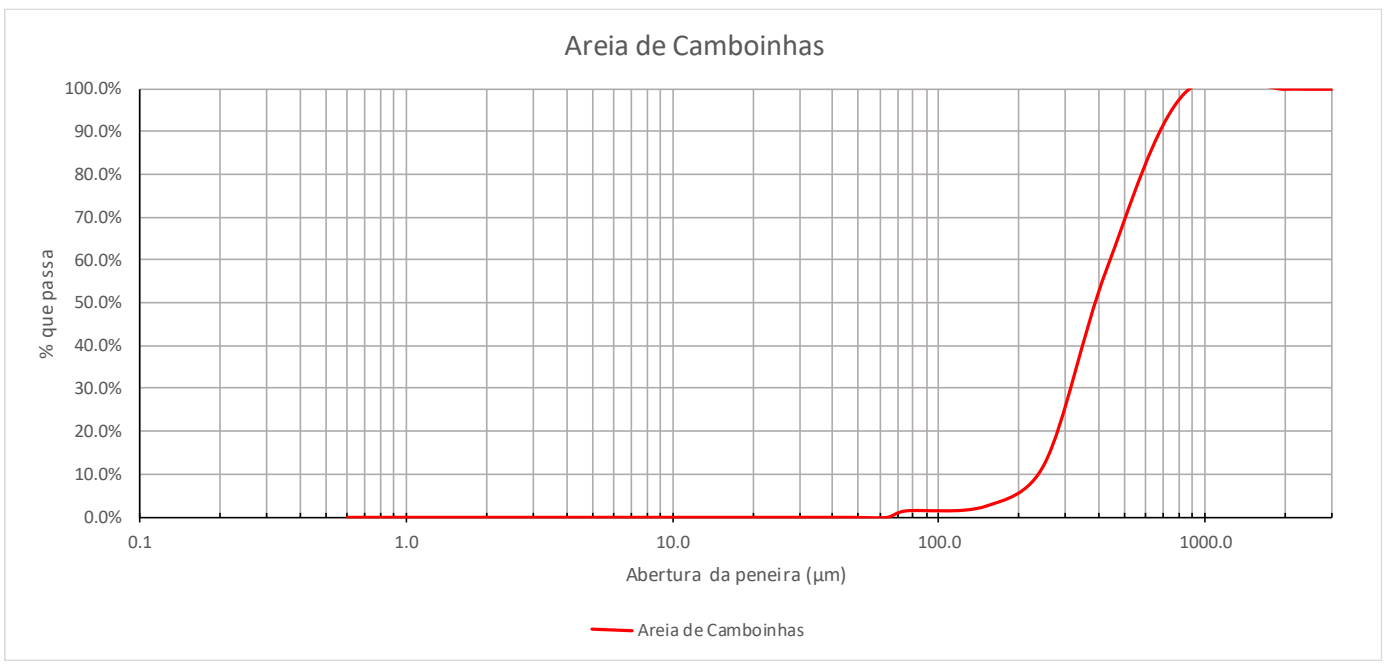

Figura 3.2 - Curva granulométrica da amostra de Camboinhas.

Tabela 3.3 - Percentual da amostra de Camboinhas.

\begin{tabular}{|c|c|}
\hline Materiais & Porcentagem \\
\hline Areia Grossa & $0.9 \%$ \\
\hline Areia Média & $86.5 \%$ \\
\hline Areia Fina & $12.6 \%$ \\
\hline Silte Grosso & $0.0 \%$ \\
\hline Silte Médio & $0.0 \%$ \\
\hline Silte Fino & $0.0 \%$ \\
\hline Argila Grossa & $0.0 \%$ \\
\hline Argila Média & $0.0 \%$ \\
\hline Argila Fina & $0.0 \%$ \\
\hline
\end{tabular}




\subsection{3.}

\section{Determinação dos Índices de Vazios Máximo e Mínimo}

Os índices de vazios máximo e mínimo foram obtidos segundo o procedimento descrito no procedimento interno do laboratório de geotecnia da PUC-Rio, tendo como base a NBR 12004/90 MB 3324. Os resultados são apresentados na Tabela 3.2.

No caso da amostra de Camboinhas, houve ligeira dificuldade na obtenção do valor médio dos índices de vazios máximo e mínimo devido à grande uniformidade granulométrica $(\mathrm{Cu}=1,8)$. Essa dificuldade é refletida nos desvios padrão sensivelmente maiores que os de Mariana.

Tabela 3.4 - Índices de vazios máximo e mínimo das amostras.

\begin{tabular}{cccc}
\hline Amos tra & emáx & emín & Desvio P adrão \\
\hline \hline Mariana & 0,961 & 0,593 & 0,007 e 0,004 \\
C amboinhas & 0,755 & 0,557 & 0,010 e 0,011
\end{tabular}

\subsection{4.}

\section{Forma dos Grãos}

A forma dos grãos foi avaliada através de fotos tiradas com microscópio óptico digital. As fotos foram tiradas com aproximações de 50 e 200 vezes e estão mostradas abaixo. Nota-se que os grãos apresentam formas arredondadas para o caso das duas amostras em estudo. Conforme Kramer (1996) o formato arredondado dos grãos pode conferir maior suscetibilidade à liquefação devido ao menor embricamento gerado. 


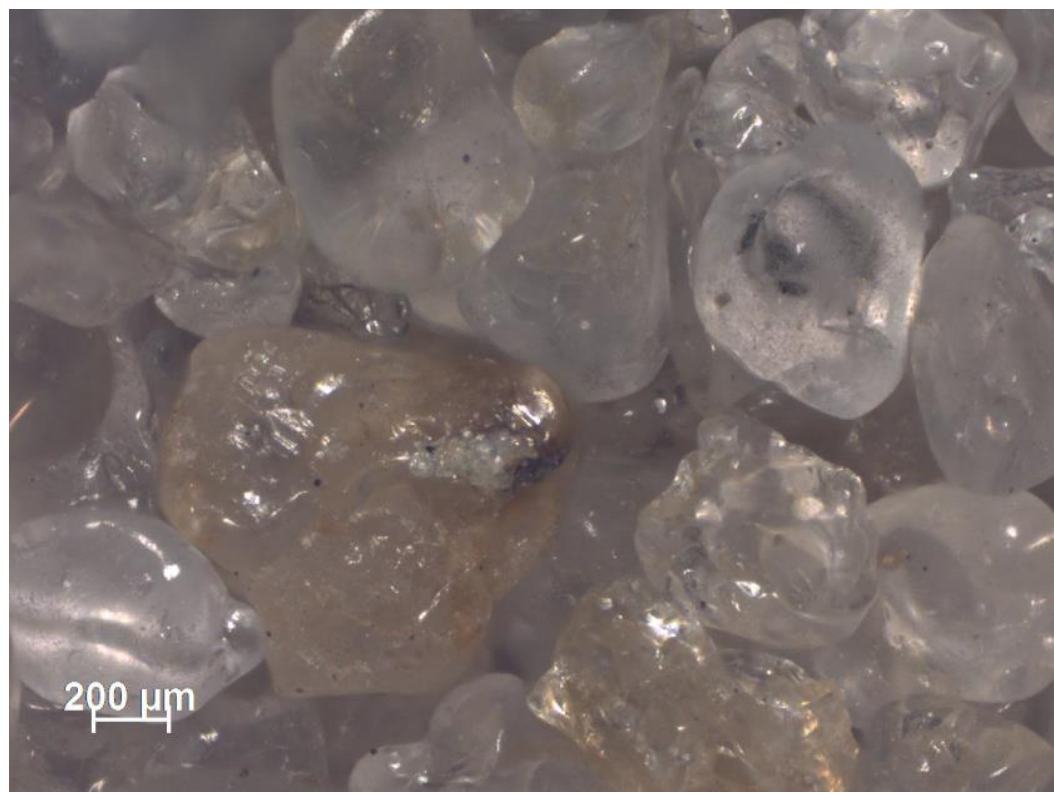

Figura 3.3 - Areia de Camboinhas ampliada 50 vezes.

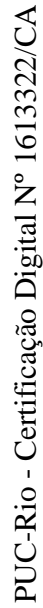

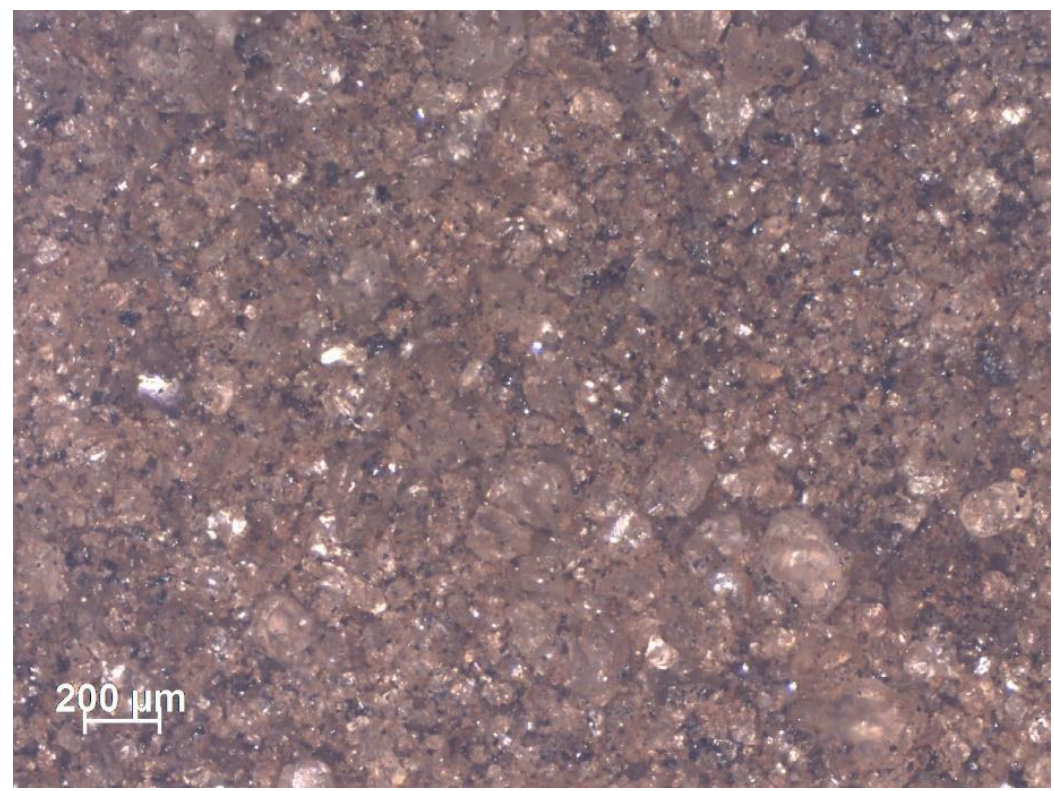

Figura 3.4 - Areia de Mariana ampliada 50 vezes. 


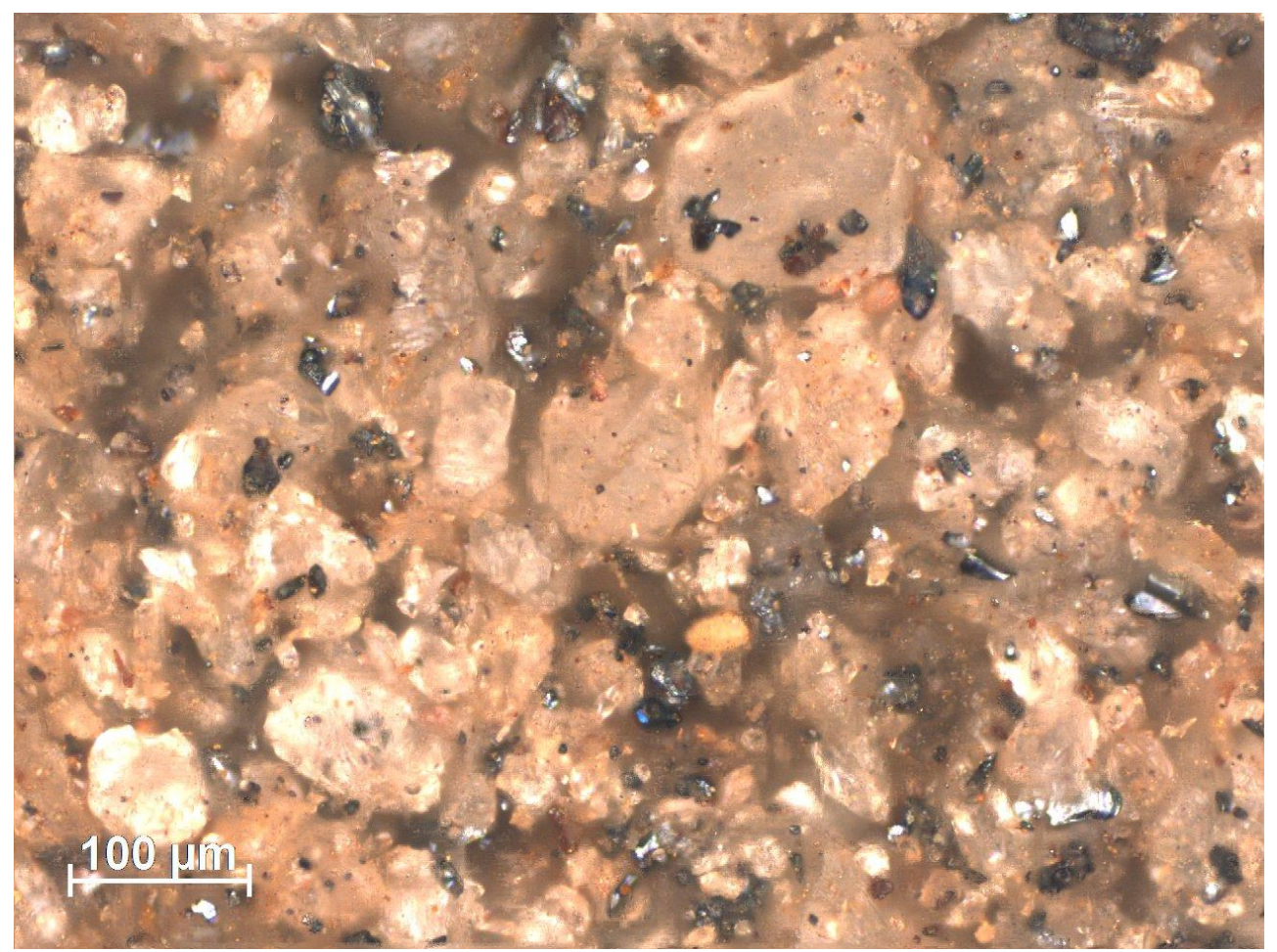

Figura 3.5 - Areia de Mariana ampliada 200 vezes.

\section{2. \\ Comportamento Tensão-Deformação Sob Condições Não Drenadas}

Ensaios triaxiais não drenados sobre areias muito fofas têm sido usados com preferência para a determinação de parâmetros de estado permanente por dois fatores. Primeiro, o aparelho triaxial é amplamente disponível. Segundo, areias muitos fofas são contrativas durante o cisalhamento e exibem aumento contínuo de poropressão sob condições não drenadas. Isso minimiza o desenvolvimento de não uniformidade dentro da amostra (Sladen at al., 1985).

\subsection{1.}

\section{Equipamento e Procedimento de Moldagem}

Utilizou-se célula triaxial de deformação controlada com célula de carga interna. As Figuras 3.6 e 3.7 apresentam o equipamento em detalhes.

Os corpos de prova foram totalmente envolvidos por uma membrana de látex com espessura de $0,3 \mathrm{~mm}$. As poropressões foram monitoradas através de transdutores de pressão calibrados. A fim de evitar os efeitos do 
tempo como "creep" volumétrico, iniciou-se o cisalhamento logo após a consolidação isotrópica. Os dados de ensaios foram corrigidos para efeito de membrana e efeitos gravitacionais para determinar a tensão no centro da amostra (Head, 1998).

Também foram incluídas as correções de geometria da amostra conforme Head (1998).

A preparação dos corpos de prova foi realizada por deposição úmida, tendo como base o procedimento sugerido por Jefferies e Been (2016). O equipamento e a metodologia utilizada estão descritos a seguir:

- Material necessário:

- Balança para $1 \mathrm{~kg}$ com precisão de 0,01g;

- Paquímetro com precisão de $0,05 \mathrm{~mm}$;

- Molde tripartido (ou bipartido) com braçadeira;

- Bomba de vácuo;

- Elemento poroso e papel filtro;

- Membrana de látex e anéis de borracha (o-rings)

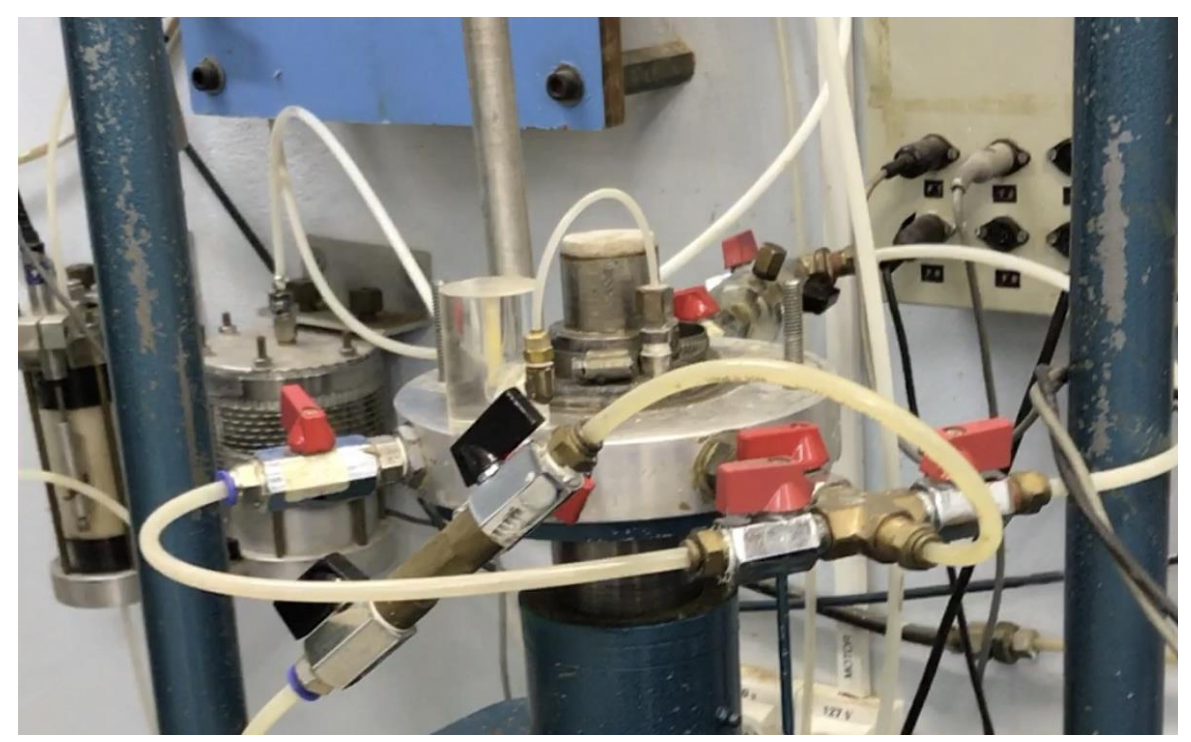

Figura 3.6 - Base da célula triaxial usada. 


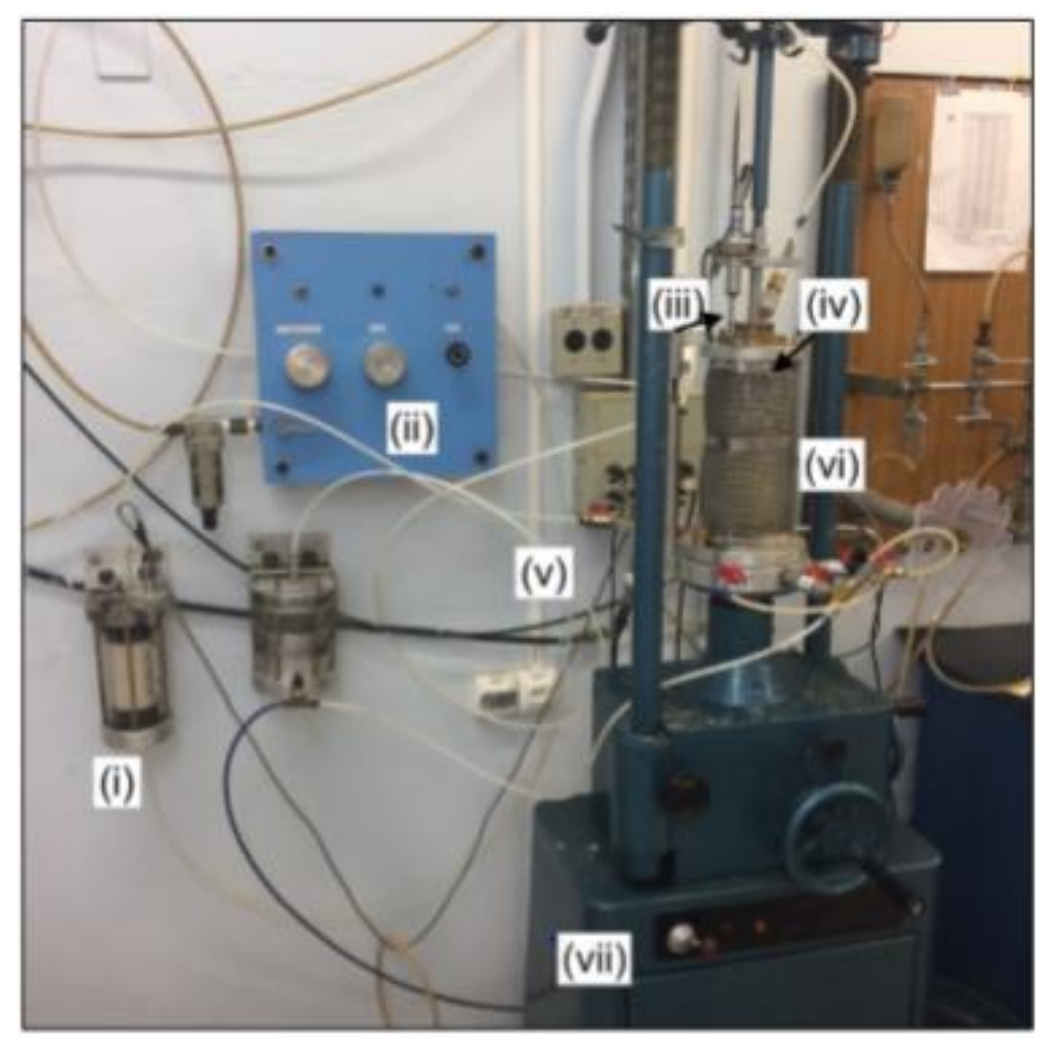

Figura 3.7 - (i) medido de variação de volume; (ii) painel de controle de pressões; (iii) LVDT; (iv) célula de carga; (v) transdutor de pressão; (vi) câmara de acrílico com grades; (vii) sistema de engrenagens para controle de velocidade de cisalhamento. (SENEZ, 2016)

- Procedimento de moldagem

Primeiro, coletava-se cerca de $250 \mathrm{~g}$ (para corpos de prova com $36 \mathrm{~mm}$ de diâmetro e $80 \mathrm{~mm}$ de altura) de solo seco em estufa e adicionava-se água suficiente para garantir um teor de umidade entre 5\% e 7\%. Logo após, iniciava-se a homogeneização da mistura.

Para definir a quantidade de solo úmido homogeneizado, necessária para moldar o corpo de prova com índice de vazios de $0,95 e_{\text {máx }}$, calculavase o peso especifico do solo úmido homogeneizado. $O$ cálculo era feito da seguinte forma:

Calculava-se o peso especifico do solo seco $\left(\gamma_{d}\right)$.

$$
\gamma_{d}=\frac{\gamma_{s}}{(1+e)}
$$

Mas, $e=0,95 e_{\text {máx }}$, então: 


$$
\gamma_{d}=\frac{\gamma_{s}}{\left(1+0,95 e_{\text {máx }}\right)}
$$

Onde: $\gamma_{s}$ é peso especifico dos grãos e $e_{\text {máx }}$ é o índice de vazios máximo do material, ambos definidos por ensaios de laboratório.

Com o peso especifico do material seco e a umidade $(w)$, calculavase o peso especifico do solo úmido com a seguinte equação:

$$
\gamma_{t}=\gamma_{d}(1+w)
$$

Definido o $\gamma_{t}$, calculava-se a quantidade de solo do corpo de prova pela equação a seguir:

$$
P_{\text {solo }}=\gamma_{t} V_{c p}
$$

Onde: $V_{c p}$ era o volume do corpo de prova.

Posteriormente, esse peso de solo úmido era então divido igualmente em quatro capsulas. O solo contido em cada capsula era depositado (sem compactação) no molde tripartido, em camadas de $20 \mathrm{~mm}$ até atingir a altura do corpo de prova $(80 \mathrm{~mm})$. As Figuras 3.8 e 3.9 mostram o procedimento de deposição.

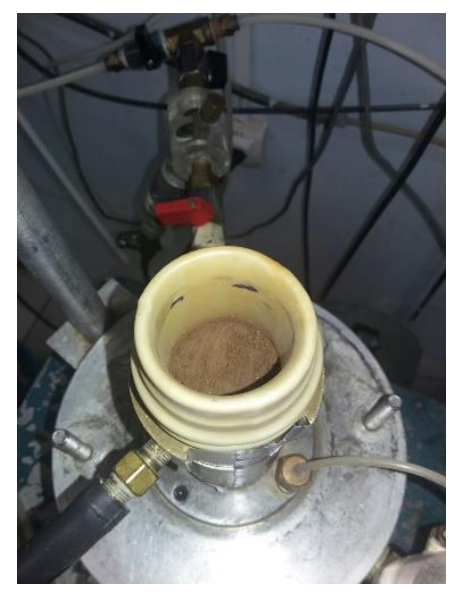

Figura 3.8- Colocação de solo no molde.

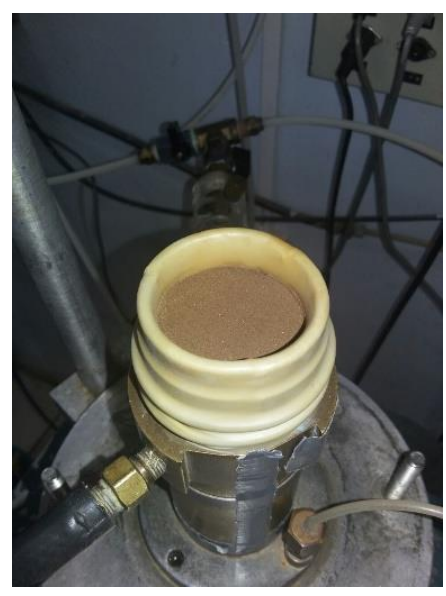

Figura 3.9- Finalização da colocação de solo no molde. 
Atingida a altura do corpo de prova, inicia-se a seguinte rotina:

1- Coloca-se a pedra porosa com papel filtro, o "top cap", e desdobra-se a membrana fixando-a com "o-rings" ao "top cap". Estas operações devem ser executadas com cuidado para mitigar as alterações das características geométricas do corpo de prova;

2- Retira-se o molde, executa-se medidas de diâmetro (base, meio e topo) e altura com o paquímetro;

3- Pesa-se a sobra de material nas cápsulas. O peso do corpo de prova será o peso inicial nas cápsulas menos o peso final;

4- Calcula-se o índice de vazios novamente com o peso de solo que realmente entrou no corpo de prova.

\subsection{2.}

\section{Saturação das Amostras}

Foram usadas amostras cilíndricas com altura média de $80 \mathrm{~mm}$ e diâmetro de $36 \mathrm{~mm}$. A densidade desejada foi alcançada com uma leve compactação quando necessário.

A saturação das amostras foi feita da seguinte forma: inicialmente, percolou-se uma quantidade de água de areada igual a duas vezes o volume da amostra em fluxo ascendente, mantendo-se uma diferença de carga máxima de $5 \mathrm{kPa}$. Após a percolação de água, aplicou-se contrapressão de $50 \mathrm{kPa}$ mantendo $10 \mathrm{kPa}$ de tensão efetiva na amostra, sendo estabelecido um nível máximo de 200kPa (Head, 1988). A amostra foi considerada saturada quando o parâmetro de poropressão $B$ de Skempton atingiu um valor mínimo de 0,95.

\subsection{3.}

\section{Adensamento das Amostras}

As amostras foram adensadas isotropicamente para tensões confinantes situadas entre $50 \mathrm{kPa}$ e $400 \mathrm{kPa}$. A drenagem foi feita pela base e as variações volumétricas foram registradas através de um medidor de variação de volume eletrônico, dotado de um sistema de aquisição de dados automático. 


\subsection{4.}

\section{Cisalhamento das Amostras}

Conforme Head (1988), a velocidade de cisalhamento é definida em função do tempo necessário para ocorrência da ruptura. Em ensaios adensados isotropicamente e não drenados, esse tempo de ruptura pode ser estimado pela seguinte expressão:

$t_{f}=1,8 t_{100}$

Onde $t_{100}$ é o tempo necessário para ocorrer $100 \%$ do adensamento. Segundo Head (1988), a velocidade de cisalhamento pode ser definida da seguinte forma:

$v=\frac{\varepsilon_{f} H_{0}}{100 t_{f}}$

Sendo $\varepsilon_{f}$ a deformação até a resistência de pico e $H_{0}$, a altura inicial da amostra. Para solos arenosos saturados, Head (1988) sugere valores variando entre $12 \%$ e 18\%. No entanto, Yamamuro e Lade (1997), Jefferies e Been (2016) e outros mostram que, no caso de ruptura por liquefação estática, o pico de resistência normalmente é atingido para valores de deformação bem menores, entre 0,1\% e 1,5\%.

A areia de Camboinhas apresentou $t_{100}=0,13 \mathrm{~min}$ e $t_{f}=0,23 \mathrm{~min}$, Assim a velocidade de cisalhamento calculada conforme Head (1988), supondo deformação na ruptura de $1,5 \%$ e $H_{0}=80 \mathrm{~mm}$, foi de 0,052 $\mathrm{mm} / \mathrm{min}$. No caso da areia de Mariana os valores de $t_{100}$ e $t_{f}$ foram de 0,63 min e 1,13 min respectivamente, a velocidade de cisalhamento calculada foi de $0,011 \mathrm{~mm} / \mathrm{min}$.

Contudo, a velocidade de deformação usada em todos os ensaios foi padronizada em 0,08 mm/min com base em Pereira (2005) e Abreu (2012).

Os deslocamentos axiais foram medidas através de um medidor de deslocamento (LVDT), as poropressões foram monitoradas por um transdutor de pressão e as cargas aplicadas foram registradas pela célula 
de carga interna. As pressões aplicadas foram controladas por válvulas de precisão. Os dados foram gravados e enviados para um sistema de aquisição automático.

\subsection{5.}

\section{Resultados Obtidos}

Os resultados dos ensaios triaxiais executados na amostra de Camboinhas estão mostrados nas Figuras 3.10a, 3.10b 3.11 e 3.12. Os resultados da amostra de areia de Mariana estão apresentados nas Figuras 3.13a, 3.13b, 3.14 e 3.15.

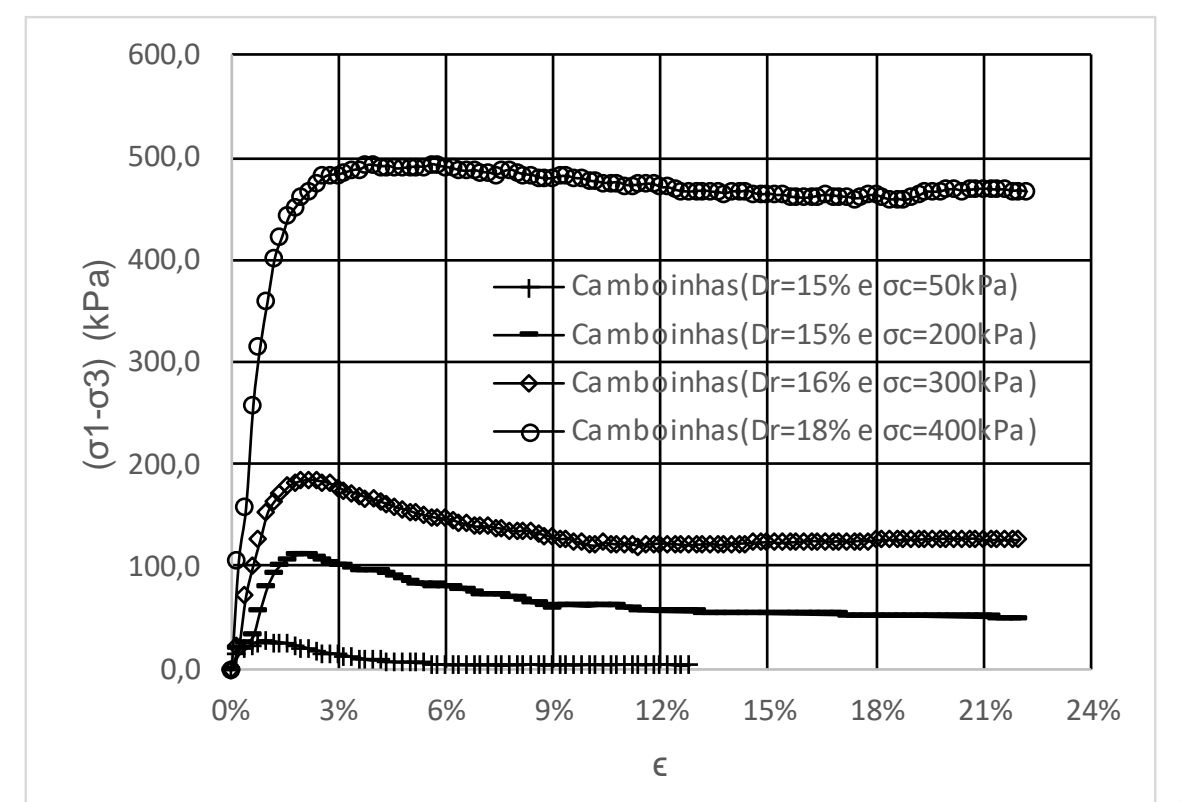

(a)

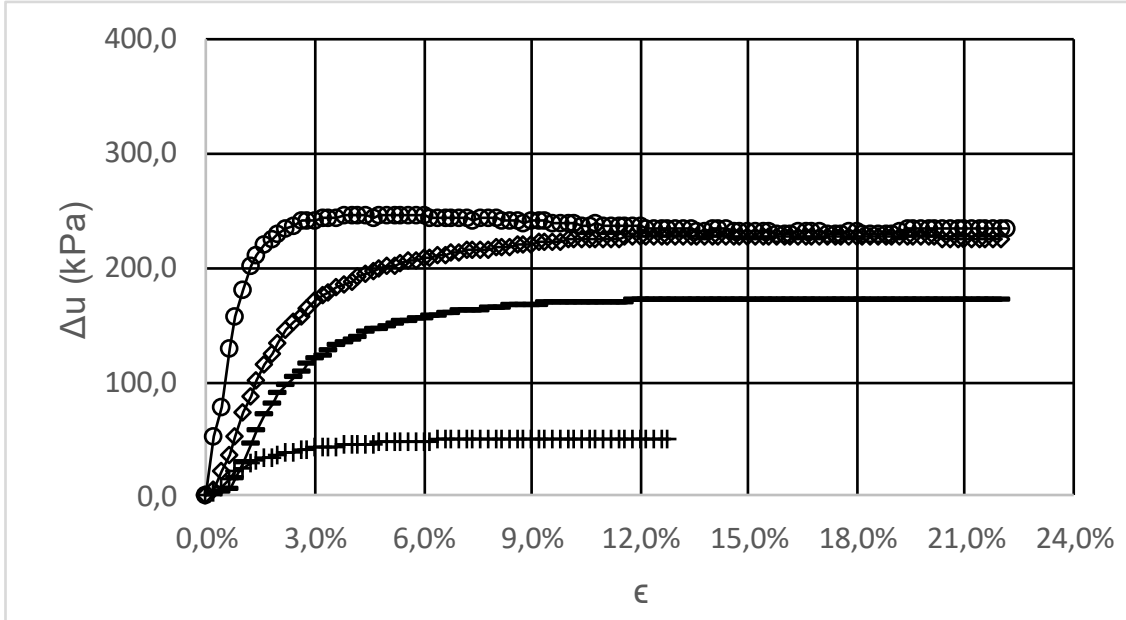

(b)

Figura 3.10 - Curvas tensão desviadora e excesso de poropressão em função da deformação para a areia de Camboinhas. 


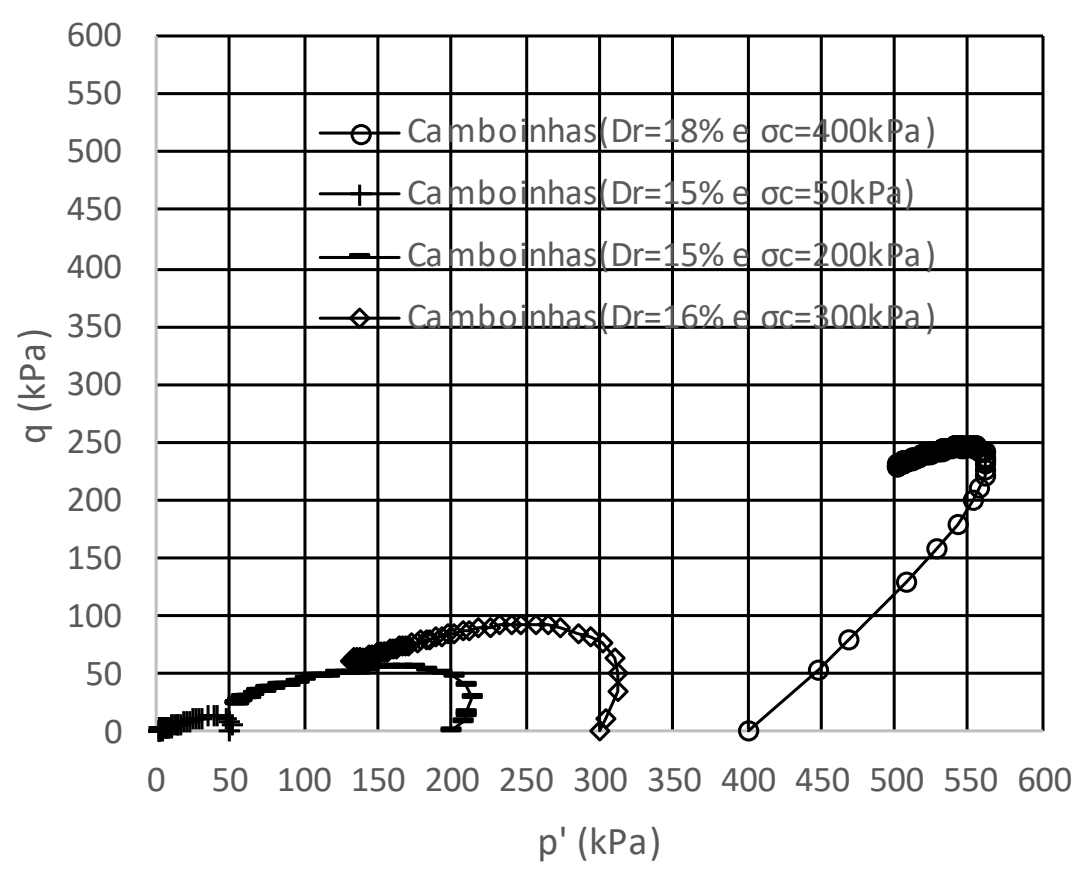

Figura 3.11 - Trajetória de tensões efetivas tipo MIT para a areia de Camboinhas.

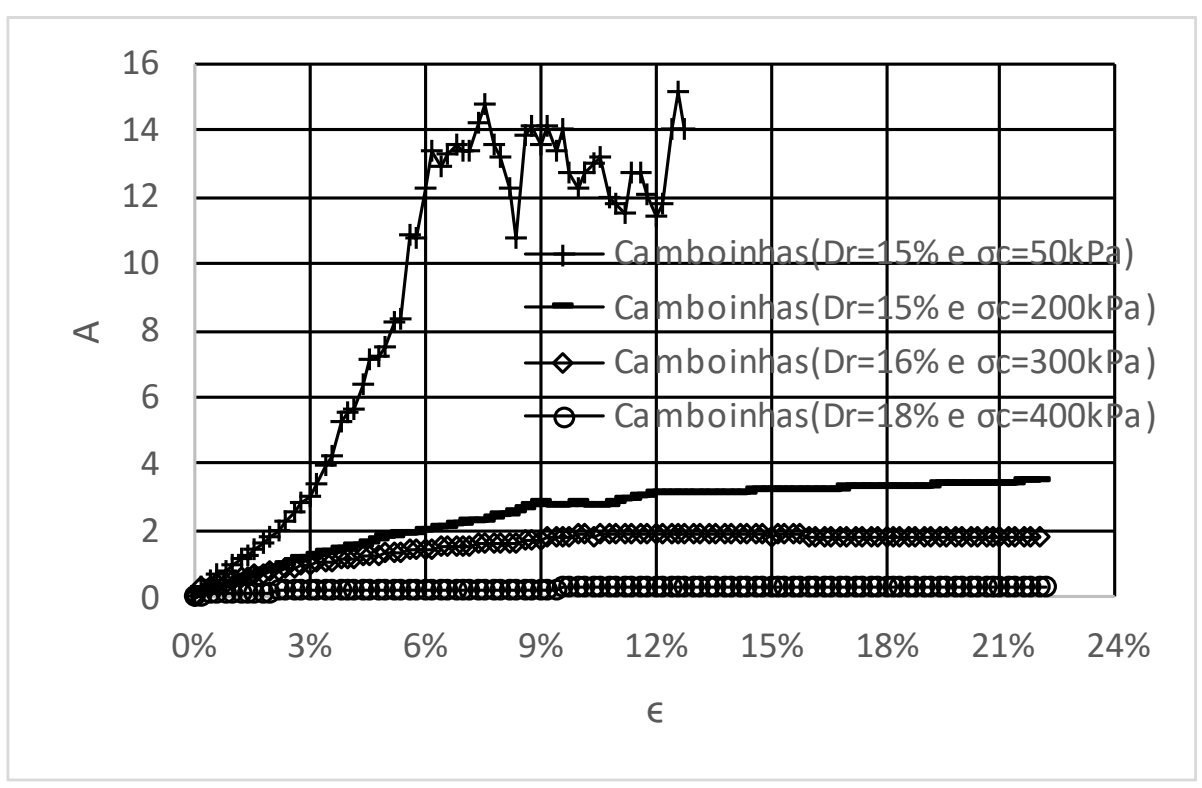

Figura 3.12 - Parâmetro A de poropressão em função da deformação para a areia de Camboinhas. 


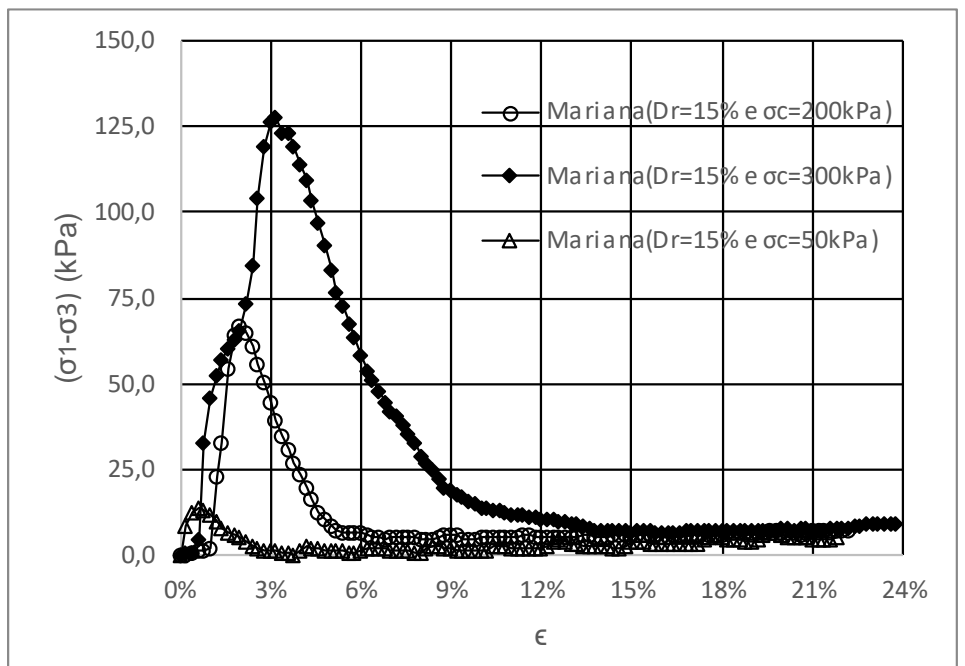

(a)

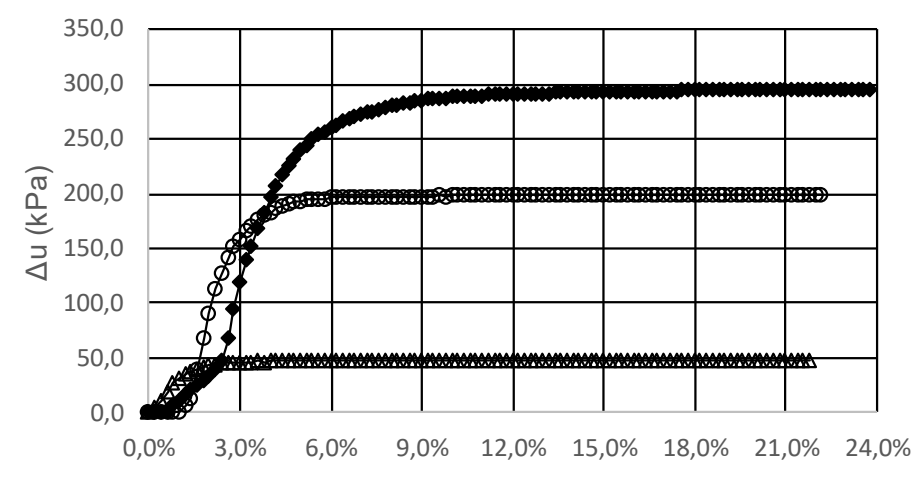

(b)

Figura 3.13 - Curvas tensão desviadora e excesso de poropressão em função da deformação para o rejeito arenoso de Mariana.

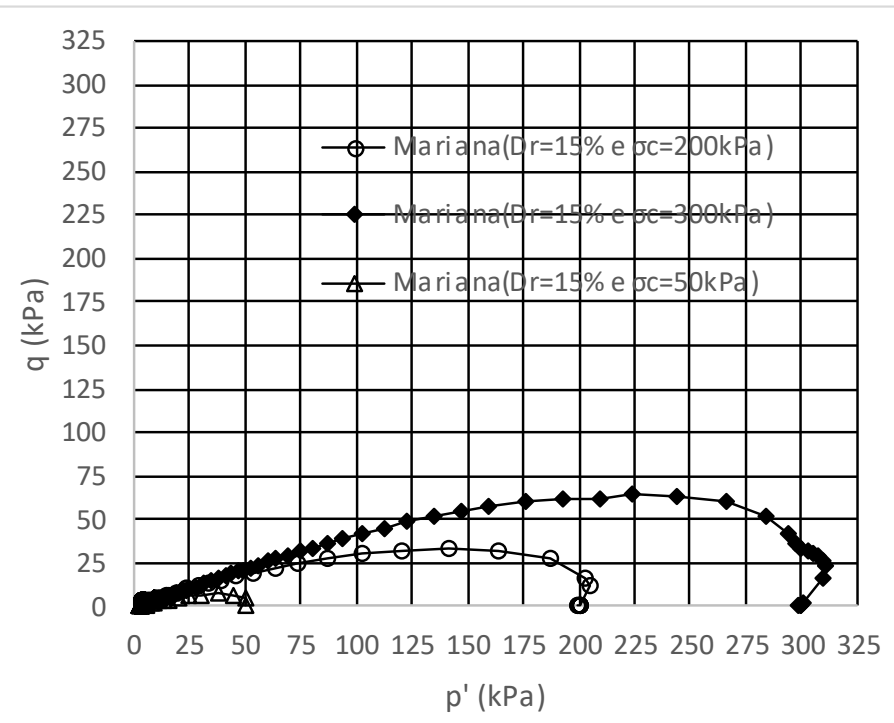

Figura 3.14 - Trajetória de tensões efetivas tipo MIT para o rejeito arenoso de Mariana. 


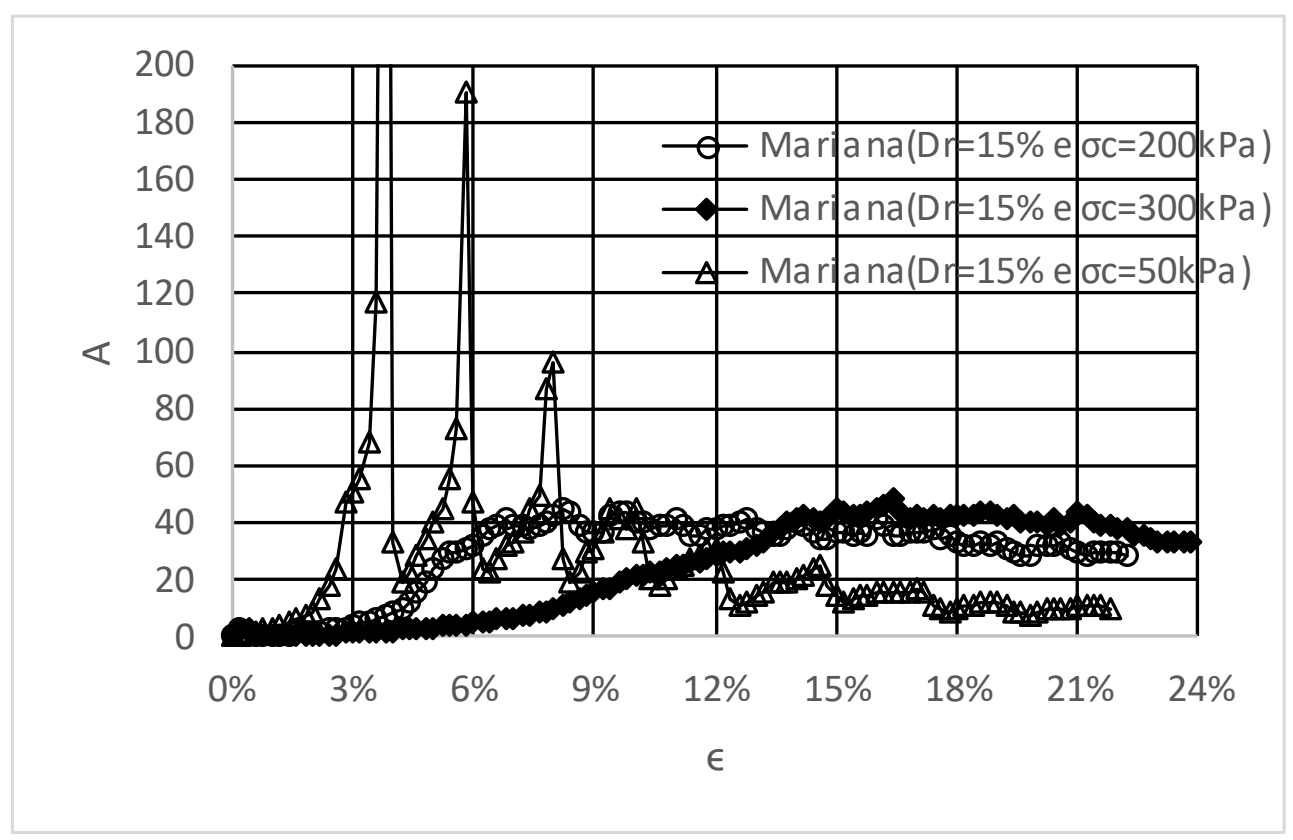

Figura 3.15 - Parâmetro A de poropressão em função da deformação para o rejeito

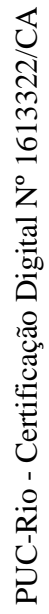
arenoso de Mariana. 


\section{Avaliação dos Resultados Obtidos}

Os resultados de granulometria foram comparados com o critério de Ishihara (1980) com a finalidade de fornecer indícios de potencial de liquefação. Os resultados dos ensaios triaxiais foram avaliados a partir de dois aspectos principais: primeiro foi delimitada a zona de instabilidade não drenada para as duas amostras estudas e, posteriormente, foi avaliado o efeito da tensão de confinamento para a ocorrência da liquefação.

\section{1.}

\section{Granulometria}

Notou-se que a areia de Camboinhas apresentou coeficiente de uniformidade $(\mathrm{Cu})$ igual a 1,8 e, conforme Lambe (1969), valores de $\mathrm{Cu}$ abaixo de 2 representam solos uniformes. Devido à essa grande uniformidade, a areia de Camboinhas foi classificada pelo critério de Ishihara et al. (1980) com elevado potencial de liquefação.

$\mathrm{O}$ rejeito arenoso de Mariana apresentou $\mathrm{Cu}$ igual a 5,7 (solo parcialmente uniforme) e foi classificado com potencial de liquefação conforme o critério de Ishihara et al. (1980). 


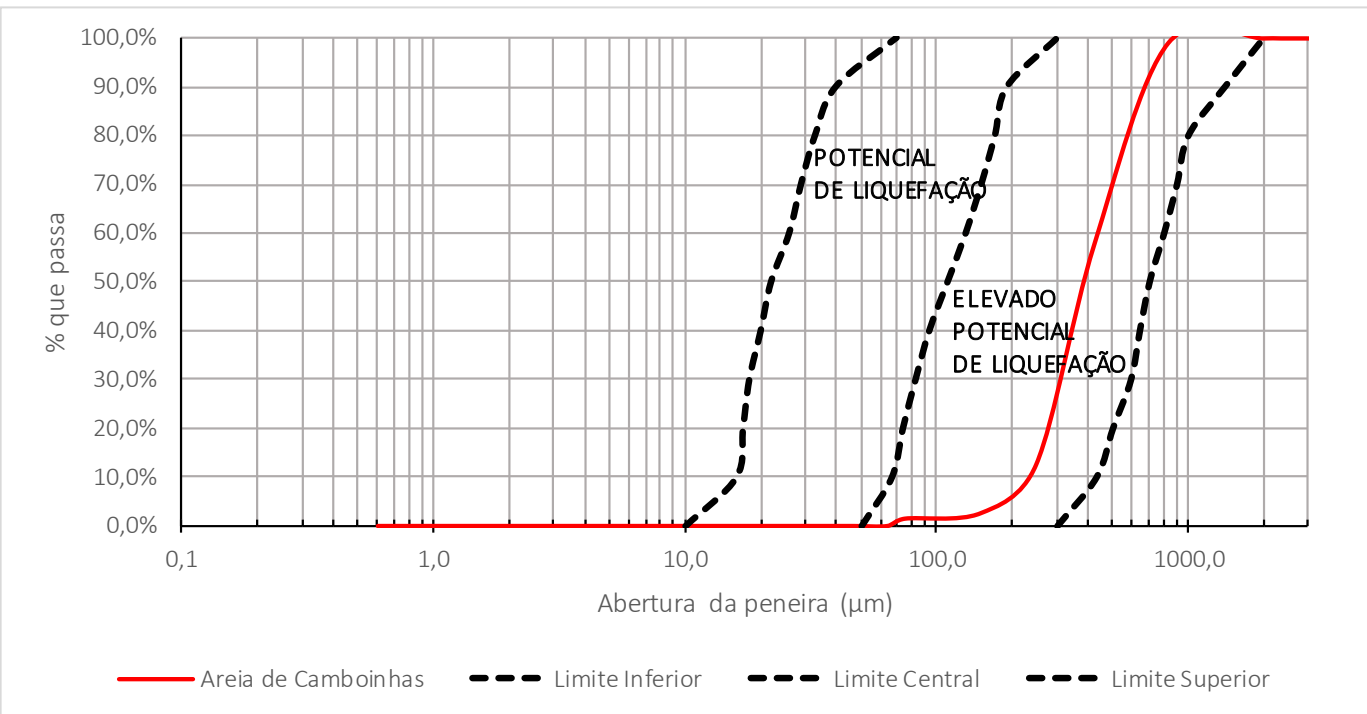

Figura 4.1- Curva granulométrica da areia de Camboinhas e limites de Ishihara et al.

(1980).

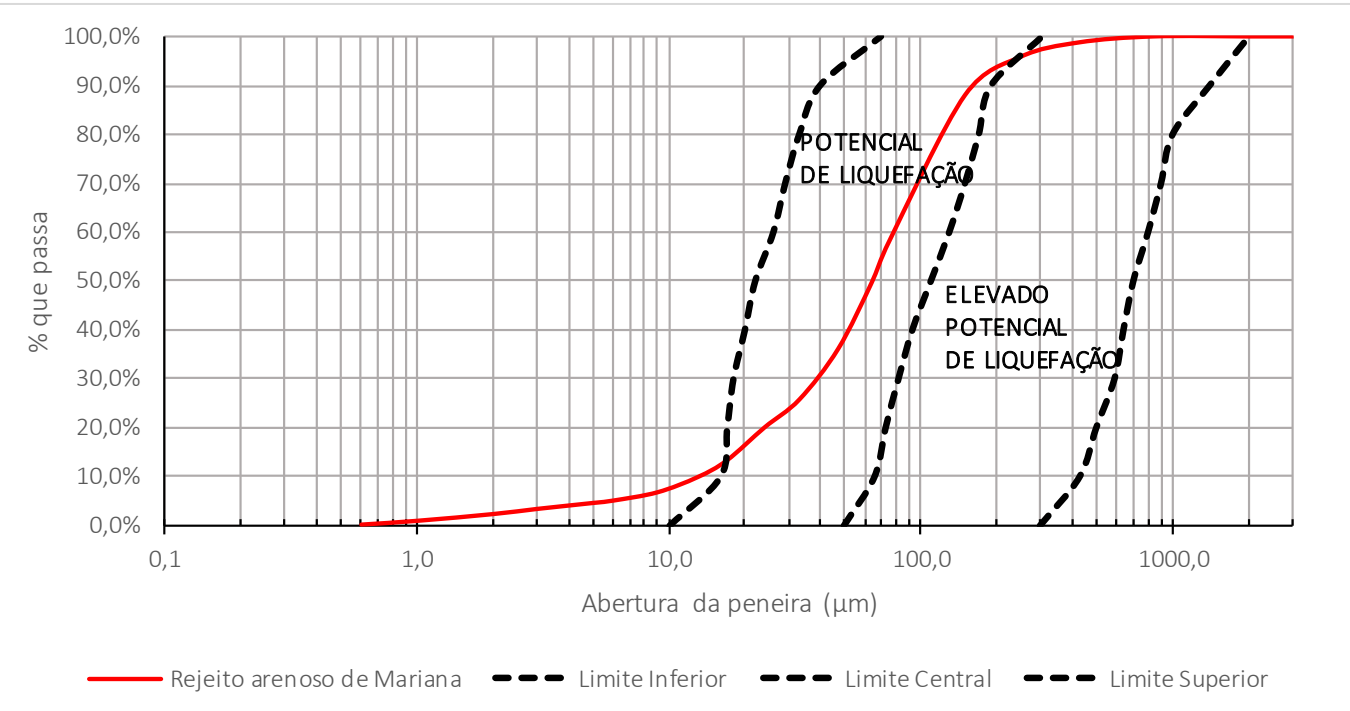

Figura 4.2 - Curva granulométrica de Mariana e limites de Ishihara et al. (1980).

\section{2.}

\section{Ensaios Triaxiais}

No geral, a areia limpa de Camboinhas apresentou aumento inicial de resistência chegando a um pico e, posteriormente, diminuição da resistência até um valor mínimo. A liquefação total foi observada apenas para o confinamento de $50 \mathrm{kPa}$, enquanto que para as tensões confinantes 
de $200 \mathrm{kPa}, 300 \mathrm{kPa}$ e $400 \mathrm{kPa}$ observou-se apenas uma instabilidade (Figuras 3.10a, 3.10b e 3.11).

O parâmetro de poropressão $A$ na ruptura foi de 1,2, 0,8, 0,8 e 0,2 para as tensões confinantes $50 \mathrm{kPa}, 200 \mathrm{kPa}, 300 \mathrm{kPa}$ e $400 \mathrm{kPa}$, respectivamente (Figura 3.12). Após a ruptura, o parâmetro $A$ subiu rapidamente para valores da ordem de 13 , no caso de confinamento baixo $(50 \mathrm{kPa})$, enquanto que para confinamento alto $(200 \mathrm{kPa}, 300 \mathrm{kPa}$ e $400 \mathrm{kPa})$ o parâmetro $A$ assumiu valores entre 2 e 4 .

No caso do rejeito arenoso de Mariana, observou-se a ocorrência de liquefação total em todas as tensões de confinamento ensaiadas $(50 \mathrm{kPa}$, $200 \mathrm{kPa}$ e $300 \mathrm{kPa}$ ). No geral, as curvas tensão-deformação mostradas nas Figuras 3.13a e 3.13b apresentaram um pico inicial de resistência seguido por uma queda até um valor mínimo razoavelmente constante. Inicialmente, as poropressões aumentam rapidamente e, logo depois, estabilizam-se num patamar até o fim do cisalhamento. As trajetórias de tensões efetivas tipo MIT, são mostradas na Figura 3.14 e evidenciam a ocorrência de liquefação total ou verdadeira do rejeito de Mariana, ou seja, p' e q chegam à valores próximos de zero para os três níveis de confinamento $(50 \mathrm{kPa}$, $200 \mathrm{kPa}$ e $300 \mathrm{kPa}$ ).

O Parâmetro A de poropressão na ruptura é igual a 1,6, 1,4 e 1,1 para tensões de confinamento de $50 \mathrm{kPa}, 200 \mathrm{kPa}$ e $300 \mathrm{kPa}$ respectivamente. Após a ruptura, o parâmetro $\mathrm{A}$ aumenta rapidamente e assume valores da ordem de 20 para o ensaio em baixo confinamento $(50 \mathrm{kPa})$, em confinamento alto $(200 \mathrm{kPa}$ e $300 \mathrm{kPa})$ foi observado o mesmo comportamento, mas $\mathrm{o}$ valor médio assumido pelo parâmetro $\mathrm{A}$ após a ruptura foi da ordem de 40 (Figura 3.15). 


\subsection{1.}

\section{Zona de Instabilidade Não Drenada}

A zona de instabilidade não drenada de um solo é a região delimitada pelas linhas de instabilidade e ruptura. Segundo Yamamuro e Lade (1997) quando o estado de tensões se encontra nessa região, pode ocorrer liquefação total, liquefação temporária, instabilidade temporária ou apenas uma instabilidade. Como apresentado anteriormente, muitos autores observaram que a liquefação total normalmente é caracterizada pelo desenvolvimento de altas poropressões, chegando a ter zero de pressão de confinamento e desviadora em baixa deformação axial. Essa é uma das características do comportamento normal de solos arenosos em estado fofo, sob condições não drenadas.

A liquefação temporária ocorre em tensões mais altas que a região de liquefação total e é caracterizada por um pico inicial na tensão desviadora, seguida por uma queda. Sob cisalhamento constante, a amostra apresenta tendências dilatantes e queda da poropressão, seguida por aumento da magnitude da tensão desviadora para valores muito mais altos que a tensão inicial de pico. Isso ocorre em grandes deformações.

A instabilidade temporária ocorre em tensões bem maiores que aquelas da região de liquefação temporária e acontece em uma região similar a região de liquefação temporária, exceto por duas diferenças significativas: a primeira é que o valor em que a tensão desviadora chega acima do pico inicial não é tão alto quanto aquele observado na liquefação temporária; A segunda diferença é que o solo exibe comportamento contrativo com o aumento da tensão confinante.

A região de instabilidade está localizada em pressões mais elevadas do que as da região de instabilidade temporária e é caracterizada por um pico inicial atingido pela tensão desviadora que, logo após, declina suavemente. Ocorre um ganho ligeiro de resistência posteriormente, mas a tensão desviadora não ultrapassa o pico inicialmente alcançado. A poropressão se mantém constante durante todo o cisalhamento.

a- Areia de Camboinhas 
A Figura 4.1 mostra as linhas de instabilidade e ruptura da areia limpa de Camboinhas. A linha de instabilidade ou linha de pico foi construída com base nas resistências de pico de cada amostra ensaiada. A linha de ruptura foi construída tangenciando-se as trajetórias de tensões das amostras ensaiadas. No caso das duas linhas foi considerado que não havia coesão. O ângulo de atrito interno no estado crítico foi determinado e vale $30^{\circ}$. Notase que a linha de instabilidade é não linear e percebe-se um aumento do ângulo de atrito de pico com o aumento da tensão confinante. Lambe e Whitman (1969) mostram que solos arenosos em estado muito fofo apresentam ângulos de atrito interno de pico menores do que no estado crítico, pois a mobilização total do ângulo de atrito não ocorre no pico de resistência e sim após o pico. A Figura 4.2 mostra a zona de instabilidade da areia de Camboinhas.

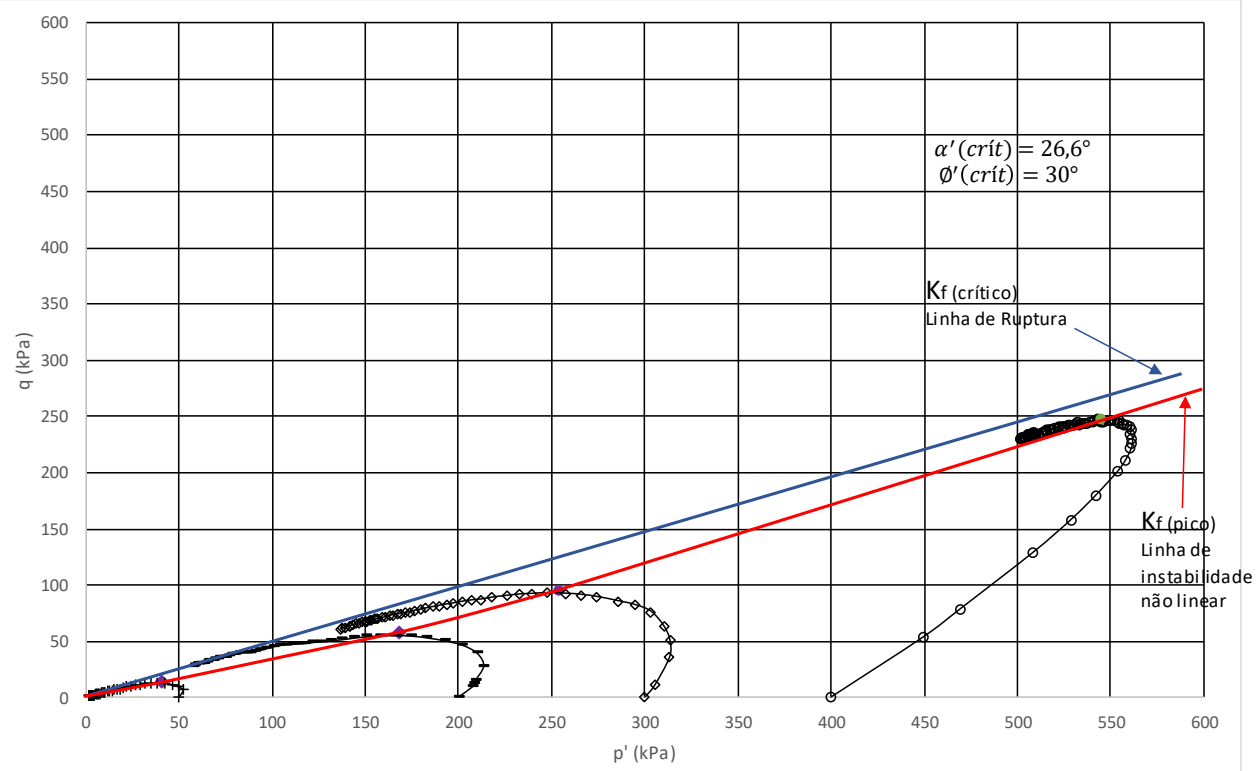

Figura 4.3 - Linhas de instabilidade e ruptura para a areia de Camboinhas. 


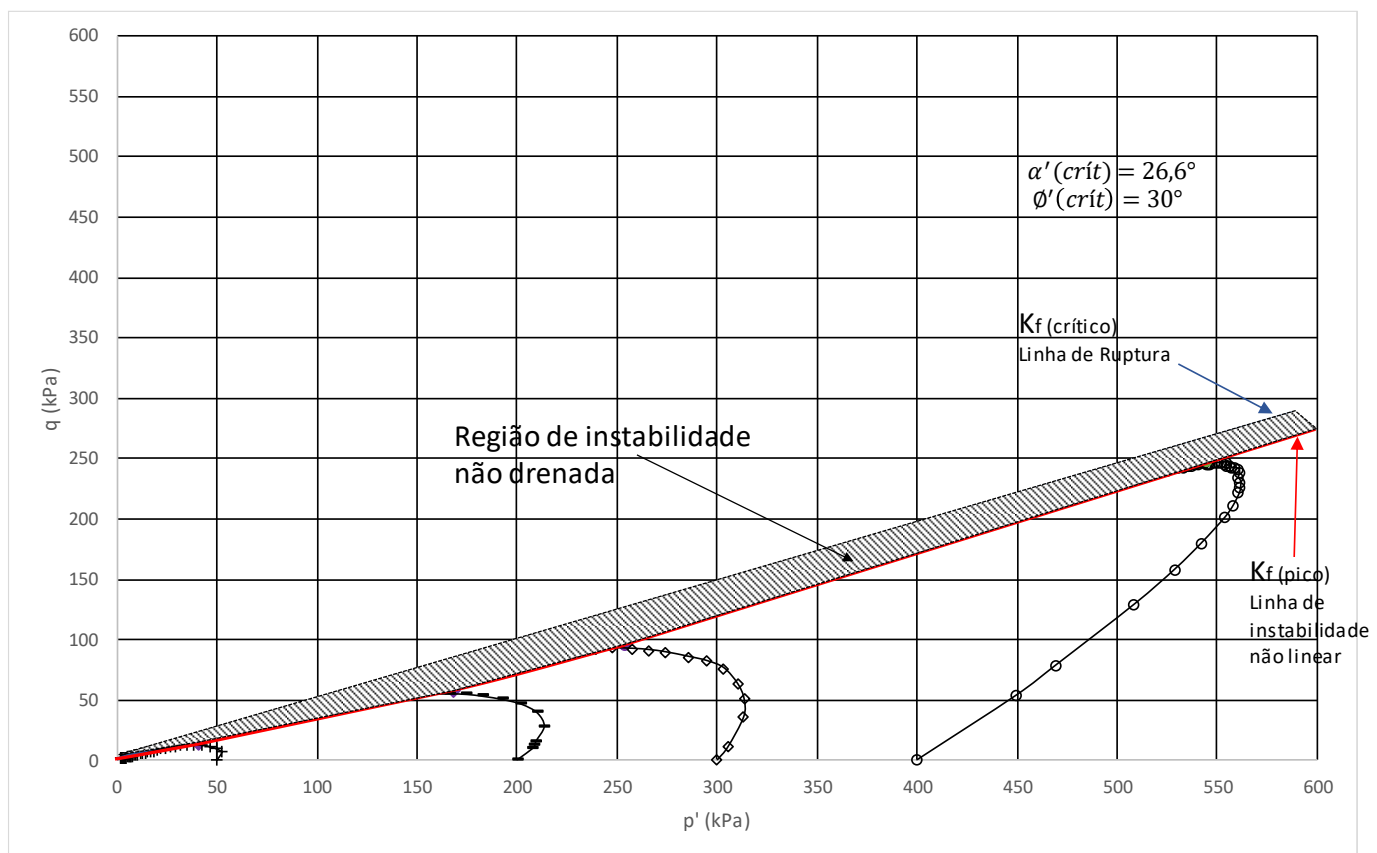

Figura 4.4 - Zona de instabilidade não drenada da areia de Camboinhas.

Todos os ensaios executados atingiram a região de instabilidade não drenada, contudo apenas o ensaio com confinamento de $50 \mathrm{kPa}$ entrou em liquefação total. Os ensaios com confinamento de $200 \mathrm{kPa}, 300 \mathrm{kPa}$ e $400 \mathrm{kPa}$ apresentaram características de uma instabilidade apenas.

\section{b- Rejeito arenoso de Mariana}

As linhas de ruptura e instabilidade estão mostradas na Figura 4.3, a linha de instabilidade é não linear assim como na areia de Camboinhas. O ângulo de atrito interno no estado crítico foi determinado e vale $24,6^{\circ}$. Percebe-se um ligeiro aumento do ângulo de atrito de pico com o aumento do confinamento. 


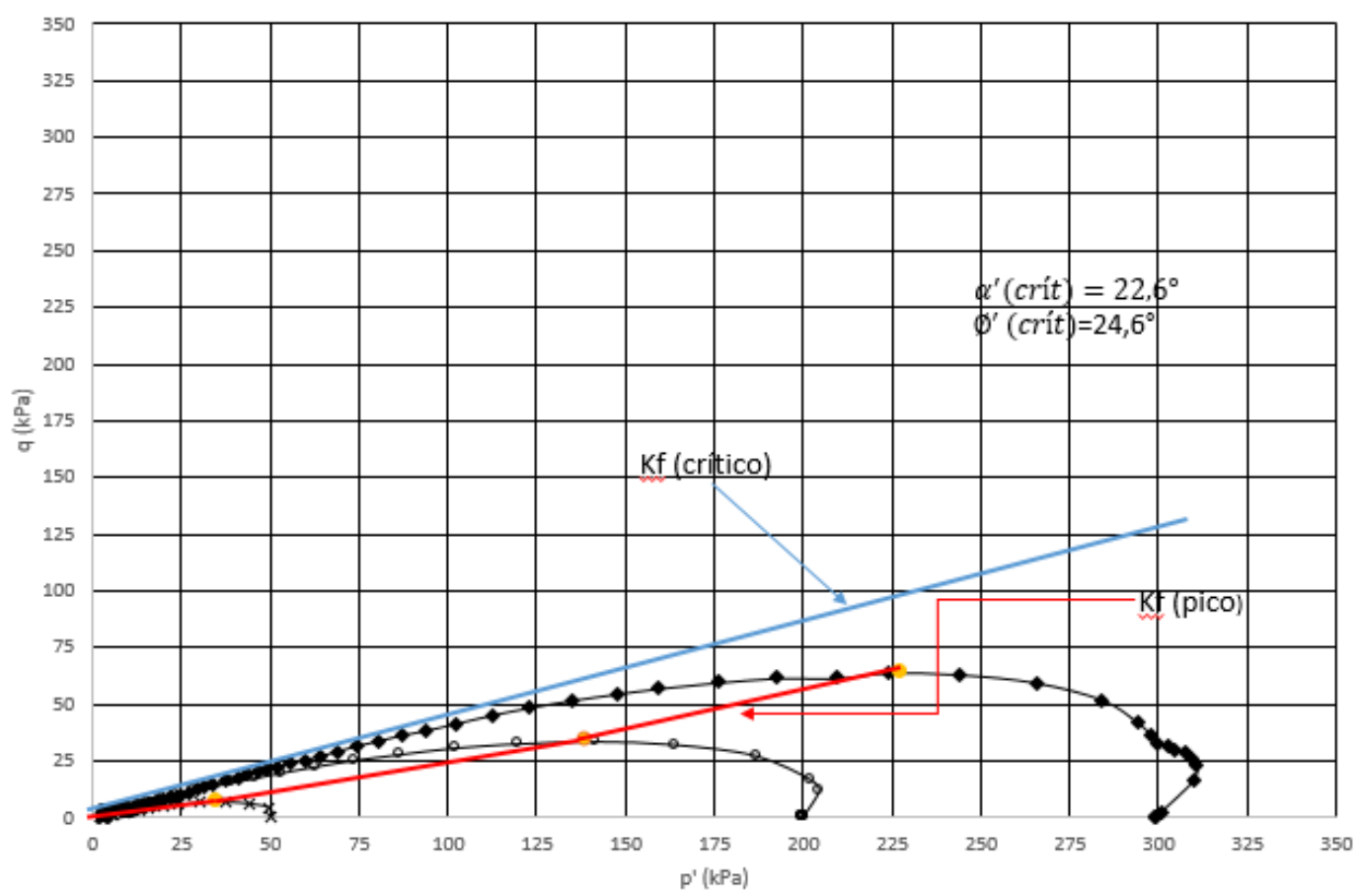

Figura 4.5 - Linhas de instabilidade e ruptura para a areia de Mariana.

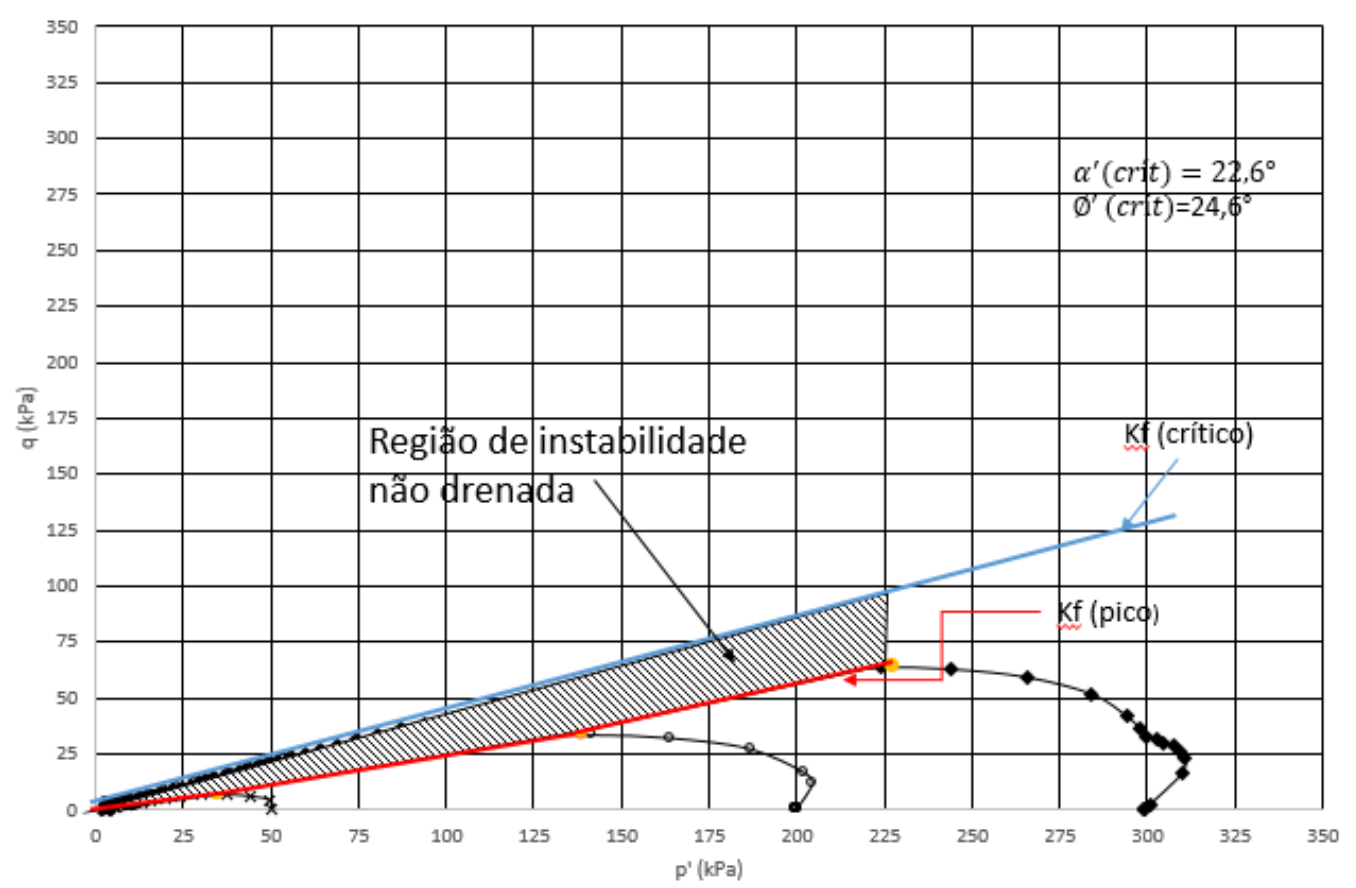

Figura 4.6 - Zona de instabilidade não drenada da areia de Mariana.

\subsection{2.}

\section{Efeito da Tensão de Confinamento}

a- Areia de Camboinhas 
O comportamento da areia limpa de Camboinhas em estado fofo sob carregamento axial não drenado mostrou-se diferente do comportamento de solo normal apresentado por Lee (1965), Seed e Lee (1967), Vaid and Chern (1985), Ishihara (1993) onde o solo é dilatante para baixos níveis de confinamento e torna-se mais contrativo com o aumento da tensão confinante. Segundo esses autores, não é possível ocorrer liquefação em baixos níveis de confinamento (até $100 \mathrm{kPa}$ ), pois nesses casos o solo apresenta comportamento dilatante.

Assim como Yamamuro e Lade (1997), observou-se liquefação total ou verdadeira para baixos níveis de tensão confinante $(50 \mathrm{kPa})$ e em confinamentos altos (acima de $200 \mathrm{kPa}$ ) ocorreu apenas uma instabilidade. O comportamento do solo em confinamento alto é caracterizado por um pico inicial de tensão desviadora e posterior queda até um valor mínimo, tendo tendências dilatantes. A curva tensão-deformação para confinamentos de $300 \mathrm{kPa}$ e $400 \mathrm{kPa}$ evidencia esse fato, após um valor mínimo ocorre um pequeno ganho de resistência que é mantido em grandes deformações.

A Figura 4.5 mostra que a resistência à liquefação aumenta com o aumento da tensão de confinamento, o que representa um comportamento inverso ao de solos arenosos com comportamento normal.

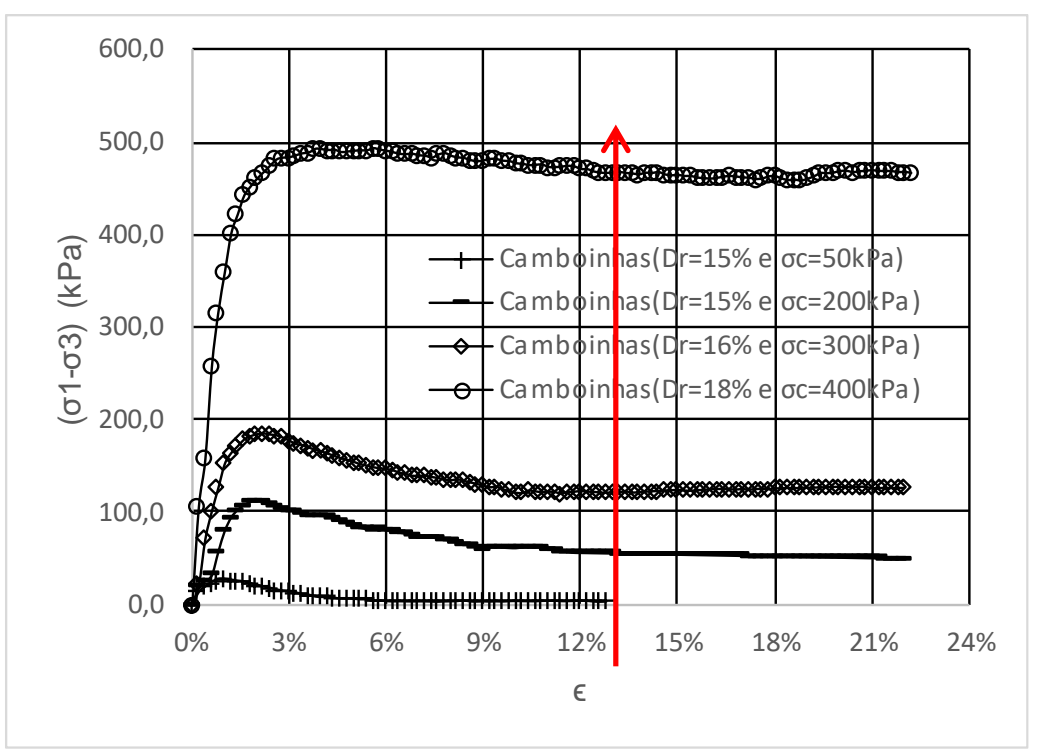

Figura 4.7 - Aumento da resistência à liquefação com o aumento da tensão confinante.

Uma outra forma de perceber o ganho de resistência à liquefação é normalizando a tensão desviadora no estado crítico com a tensão 
desviadora de pico: quanto mais essa relação se aproxima da unidade, mais estável é o solo, sendo o valor 1 a condição de estabilidade total; Quanto mais próximo de zero, mais instável é o solo, para essas situações entende-se que o solo entrou em estado de liquefação. A Figura 4.6 apresenta esta abordagem para a areia de Camboinhas, mostrando que com o aumento da tensão confinante, a tensão desviadora no estado crítico normalizada pela tensão de pico se aproxima de 1. Com isso, o solo se torna mais estável.

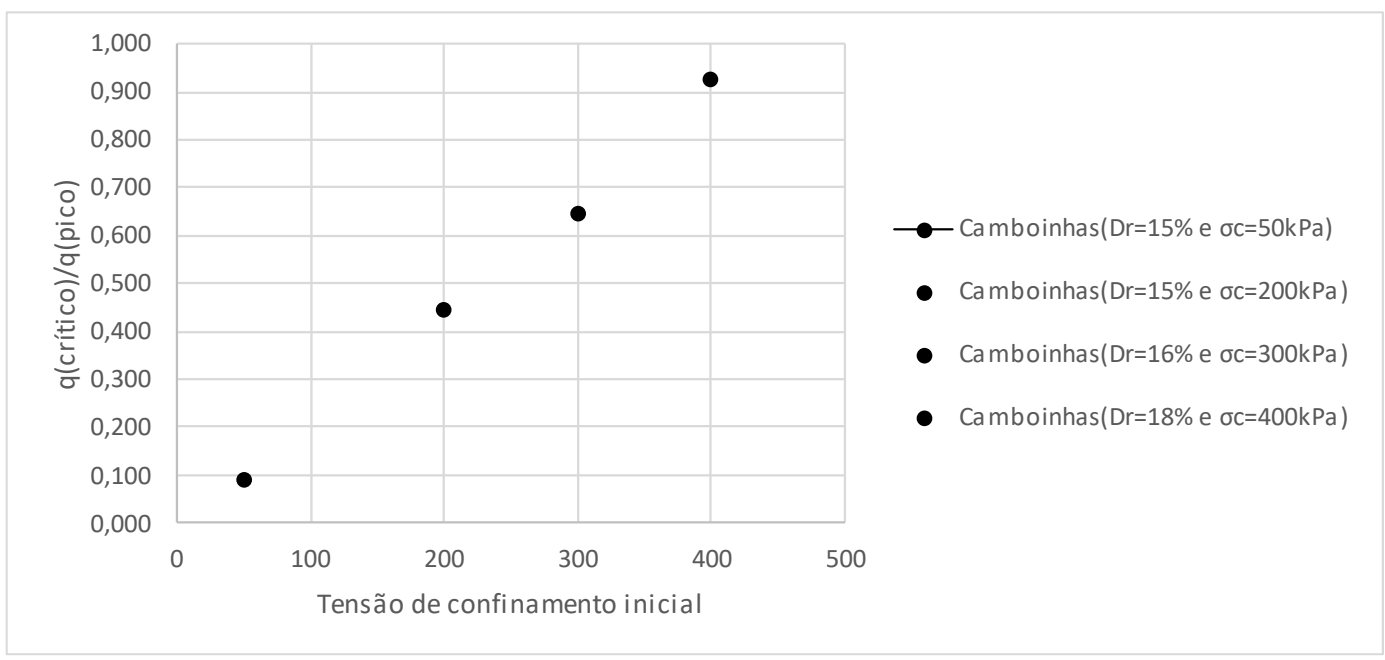

Figura 4.8 - Tensão desviadora crítica normalizada pela tensão desviadora de pico e ajuste linear para a areia de Camboinhas.

b- Rejeito Arenoso de Mariana

O comportamento do rejeito arenoso de Mariana é diferente do comportamento apresentado pela areia limpa de Camboinhas. Em níveis de confinamento alto o rejeito arenoso não apresenta aumento de resistência à liquefação, mas na verdade ocorre queda da resistência contra liquefação, como pode ser evidenciado na Figura 4.7. A tensão desviadora no estado crítico normalizada pela tensão desviadora de pico diminui com o aumento da tensão confinante, mostrando que o solo fica mais instável, esse comportamento é oposto ao da areia de Camboinhas e semelhante ao comportamento padrão de solos arenosos em estado fofo. 


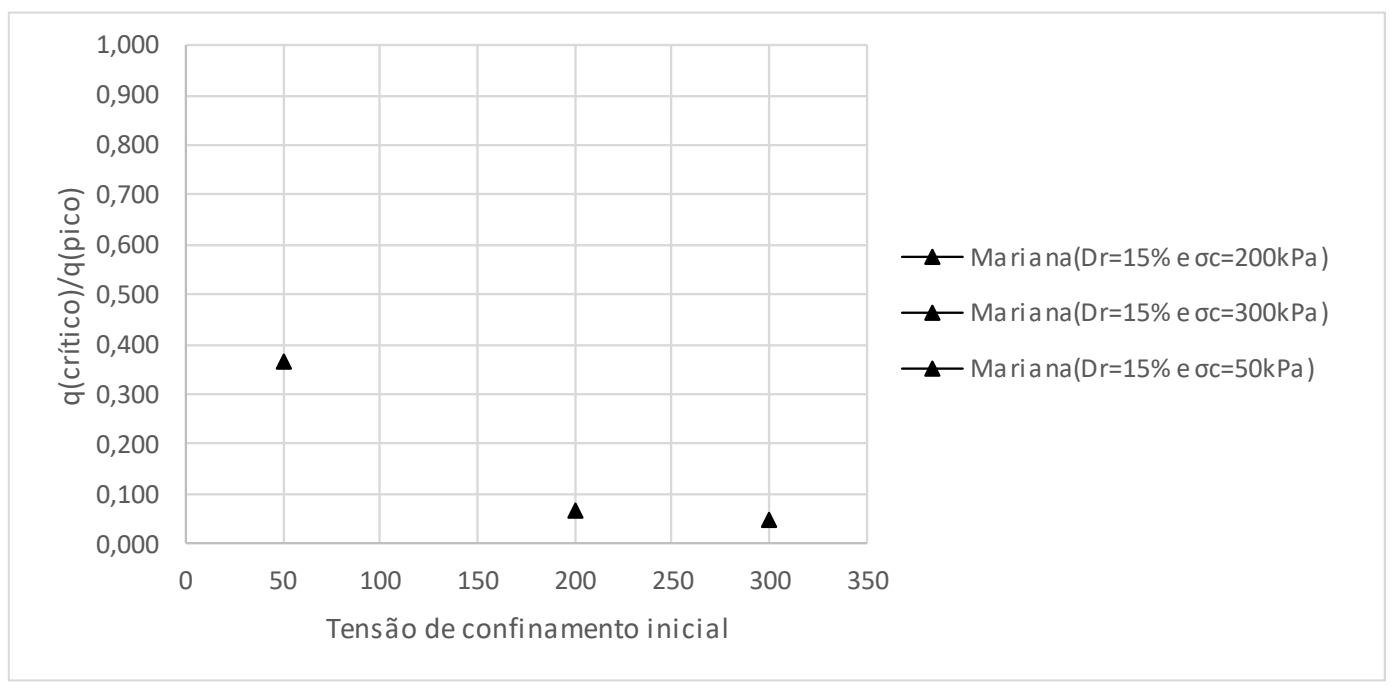

Figura 4.9 - Tensão desviadora crítica normalizada pela tensão desviadora de pico e ajuste polinomial para o rejeito arenoso de Mariana. 


\section{5 \\ Conclusões e Sugestões}

\section{1. Conclusões}

Tendo em vista que o objetivo principal deste trabalho é o de verificar a ocorrência ou não de liquefação estática nas amostras de rejeito arenoso de Mariana e areia limpa de Camboinhas, quando solicitadas por carregamento não drenado em estado fofo, a seguir são apresentadas as principais conclusões a respeito de cada areia.

\section{Areia de Camboinhas:}

Os resultados mostram que a areia limpa de Camboinhas entra em liquefação total para tensões de confinamento baixas (até $50 \mathrm{kPa}$ ). Para tensões de confinamento mais altas (acima de 200kPa) observou-se apenas uma instabilidade do solo e não a ocorrência da liquefação total como se esperava. A areia de Camboinhas apresentou um comportamento inverso ao comportamento normal (padronizado) de solos arenosos. Solos arenosos com comportamento normal apresentam baixa tendência a liquefação sob baixas tensões de confinamento e diminuem a resistência a liquefação com o aumento da tensão de confinamento. Esse padrão de comportamento foi exatamente oposto ao padrão observado para a areia de Camboinhas.

A areia de Camboinhas apresentou ganho considerável de resistência com o aumento do confinamento, chegando a um nível de quase estabilidade total quando confinada a $400 \mathrm{kPa}$. Portanto, mesmo em estado inicial muito fofo e sob carregamento estático não drenado, dificilmente essa areia entraria em liquefação quando confinada em altas tensões (acima de $200 \mathrm{kPa}$ ). Por outro lado, caso essa areia fosse carregada estaticamente em confinamento baixo ocorreria liquefação total, no caso de 
confinamento igual a $50 \mathrm{kPa}$ a liquefação ocorreria quando a tensão desviadora chegasse em $28 \mathrm{kPa}$.

Nota-se também que a areia de Camboinhas atendeu parcialmente 0 critério de Ishihara et. al. (1980), que a classificou com alto potencial de liquefação, pois em baixa tensão confinante houve liquefação, mas em altas tensões não.

A linha de instabilidade não drenada é não linear e verificou-se um ligeiro aumento do ângulo de atrito efetivo.

\section{Rejeito Arenoso de Mariana:}

No caso do rejeito arenoso de Mariana, os resultados mostraram que houve liquefação total para todas as tensões de confinamento ensaiadas. Contudo, em confinamento baixo $(50 \mathrm{kPa})$, a amostra entra em liquefação total com certa dificuldade, pois em baixas tensões ocorre ganho de resistência contra a liquefação. Esse comportamento é semelhante ao comportamento normal (padronizado) de solos arenosos apresentado por Lee (1965), Seed e Lee (1967), Vaid (1985) e Ishihara (1993).

Portanto, em estado inicial muito fofo e sob carregamento não drenado, o rejeito arenoso de Mariana entraria em liquefação total quando confinado em altas ou baixas tensões, sendo que em confinamentos acima de $200 \mathrm{kPa}$ a liquefação ocorreria com mais facilidade.

Percebe-se que o rejeito arenoso de Mariana atendeu ao critério de Ishihara et. al. (1980), que o classificou com potencial de liquefação. Em altas e baixas tensões de confinamento o critério foi plenamente atendido.

O rejeito arenoso de Mariana também apresentou uma linha de instabilidade não drenada não linear, além de um ligeiro aumento do ângulo de atrito efetivo.

Como conclusão geral deste trabalho, pode-se dizer que, com base nos métodos de análise utilizados e nos níveis de tensão pesquisados, areias em estado fofo, sob carregamento não drenado e suscetíveis a liquefação estática, nem sempre entram em liquefação (caso da areia de Camboinhas). Afirmar que uma areia sob tais condições entraria em liquefação sem base experimental específica não é razoável. 


\section{2.}

\section{Sugestões para futuros trabalhos}

1- Executar ensaios triaxiais de tensão controlada nas areias de Camboinhas e Mariana, e compará-los com os resultados obtidos nesta dissertação. Verificar se o padrão de comportamento se mantém em tensões confinantes superiores à $500 \mathrm{kPa}$;

2- Avaliar a influência do nível de saturação e densidade relativa na liquefação total das duas areias;

3- Utilização de outros métodos de análise, como o método de índice de fragilidade não drenada de Bishop (1967). 


\section{6 \\ Referências bibliográficas}

ABREU, E. J. A. Estudo das Condições de Liquefação da Areia de Coimbra em Triaxial Estático e Cíclico. 145f. Dissertação (Mestrado em Engenharia Civil) - Faculdade de Engenharia da Universidade do Porto, Porto, 2012.

ASSOCIAÇÃO BRASILEIRA DE NORMAS TÉCNICAS. NBR 7181: Solo Análise granulométrica. Rio de Janeiro-RJ, 1984.

ASSOCIAÇÃO BRASILEIRA DE NORMAS TÉCNICAS. NBR 6457: Amostras de solo - Preparação para ensaios de compactação e ensaios de caracterização. São Paulo: Associação Brasileira de Normas Técnicas, 1986. 9 p.

ASSOCIAÇÃO BRASILEIRA DE NORMAS TÉCNICAS. NBR 6508: Solo Determinação da massa específica. Rio de Janeiro/RJ, 1984.

ASSOCIAÇÃO BRASILEIRA DE NORMAS TÉCNICAS. NBR 12004: Solo - Determinação do índice de vazios máximo de solos não coesivos. Rio de Janeiro-RJ, 1990.

ASSOCIAÇÃO BRASILEIRA DE NORMAS TÉCNICAS. NBR 12051: Solo - Determinação do índice de vazios mínimo de solos não coesivos. Rio de Janeiro-RJ, 1991.

ATUKORALA, U.; WIJEWICKREME, D.; MCCAMMON, N. Some Observations Related to Liquefaction Susceptibility of Silty Soils. 12WCEE, 2000.

ATKINSON, J. The Mechanics of Soils and Foundations (Through Critical State Soil Mechanics). McGraw-Hill International. London, 1993.

BEEN K.; JEFFERIES G. M.; HACHEY J. The Critical States of Sands. Géotechnique 41, ํㅡ 3, pg 365-381, 1991. 
BENDIN, J.; SCHNAID F.; FONSECA V. A.; COSTA FILHO DE M. L. Gold tailings liquefaction under critical state soil mechanics. Géotechnique 62, ํㅜ 3, pg 263-267, 2012.

BRAY, J. Assessment of the Liquefaction Susceptibility of FineGrained Soils. American Society of Civil Engineers. California, USA, 2006.

BRAY, J; SANCIO, R; RIEMER, M; DURGUNOGLU, H. Liquefaction Susceptibity of Fine-Grained Soils. American Society of Civil Engineers. California, USA, 2006.

CARRERA, A.; COOP, M.; LANCELLOTTA, R. Influence of grading on the mechanical behaviour of Stava tailings. Géotechnique, v. 61, n. 11, p. 935-946, 2011.

CASTRO, G. Liquefaction of Sands. Soil Mechanics Series, n. 81, Cambridge: Harvard University, 1696.

CASTRO, GONZALO; POULOS, J. ESTEVE. Factors Affecting Liquefaction and Cyclic Mobility. Journal of Geotechnical Engineering, Vol 103, no GT6, 1977.

DIANA, W. Critical State Framework and Liquefaction of Fine-Grained Soils. Thesis of Master. Department of Civil and Environmental Engineering, Washington State University, Washington, USA, 2009.

DE MELLO, VICTOR F. B. Acidentes em Barragens. Congresso Brasileiro de Mecânica dos Solos, Belo Horizonte, MG, 1966.

HEAD, K. H.. Manual of Soil Laboratory Testing. London, UK, 1998.

IDRISS, I. M. Recent Advances in Liquefaction of Fine Grained Soils. Fifth International Conference on Recent Advances in Geotechnical Earthquake Engineering and Soil Dynamics and Symposium in Honor of Professor I.M. Idriss, San Diego California, USA, 2010.

ISHIHARA, K. Liquefaction and Flow Failure During Earthquakes. Géotechnique 43, ํo 3, 351-415, 1993.

ISHIHARA, K., TRONCOSO, J. KAWASE, Y and TAKASHIMI, Y. Cyclic Strength Characteristics of Tailings Materials. Soils and Foundations, Japanese Society of Soils Mechanics and Foundations Engineering, v. 20, n. 4, p 128-142, 1980. 
JEFFERIES, M. G; BEEN, K. Soil Liquefaction A Critical State Approach. Taylor \& Francis, London \& New York, 2006.

JEFFERIES, M. G; BEEN, K. Soil Liquefaction A Critical State Approach. Taylor \& Francis, London \& New York, 2016.

JEFFERIES, M. G; BEEN, K; HACHEY, J. The Critical State of Sands. Geotechnique 41, № 3, 365-381, 1991.

KRISHNASWAMY, N; ISAAC N. Liquefaction Analysis of Saturated Reinforced Granular Soils. American Society of Civil Engineers, 1995.

LAMBE, W; WHITMAN, R. Soil Mechanics. Massachusetts Institute of Technology, 1969.

MARK, E; SHENGPING, Z. Liquefaction Behavior of Sand-Gravel Composites. American Society of Civil Engineers (ASCE). 1995.

OLSON, S. Static Liquefaction Flow Failure of the North Dike of Wachusett Dam. American Society of Civil Engineers (ASCE), 1997.

PEREIRA, Eleonardo Lima. Estudo do Potencial de Liquefação de Rejeitos de Minério de Ferro sob Carregamento Estático. Dissertação de Mestrado. Departamento de Engenharia Civil, Universidade Federal de Ouro Preto, Ouro Preto, 2005.

POULOS, J. S. et. al. Liquefaction Evaluation Procedure. Journal of Geotechnical Engineering, Vol 111, ํo 6, 1985.

POULOS, J. S. et. al. The Steady State of Deformation. Journal of Geotechnical Engineering, Vol 107, p. 553-562, 1981.

SKOPEK, P. et. al. Collapse of Dry Sand. Canadian Geotechnical Journal, 1994.

REZENDE, Viviane Aparecida. Estudo do Comportamento de Barragem de Rejeito Arenoso Alteada por Montante. Dissertação de Mestrado. Departamento de Engenharia Civil, Universidade Federal de Ouro Preto, Ouro Preto, 2013.

ROBERTSON, K. P. Evaluation of Flow Liquefaction and Liquefied Strength 
Using the Cone Penetration Test. Journal of Geotechnical and Geoenvironmental Engineering, Vol 136, n6, 2010.

ROBERTSON, K. P. Discussion of Liquefaction Potential of Silts from CPTu. Canadian Geotechnical Journal, 44:1-19, 2007.

ROBERTSON, K. P.; CAMPANELA G. R. Liquefaction Potential of Sands Using the CPT. Journal of Geotechnical Engineering, Vol 111, ํㅜ 3, 1985.

SCHOFIELD, A.; WROTH, P. M. Critical State Soil Mechanics. Cambridge University, Cambridge, USA.

SENEZ, P. C. Comportamento de uma areia reforçada com fibras de polietileno tereftalato (PET). Dissertação de Mestrado. $124 \mathrm{f}$. Pontifícia Universidade Católica do Rio de Janeiro, Rio de Janeiro, 2016.

SLADEN, A. J.; HOLLANDER, D. R.; KRAHN, J. The liquefaction of Sands, A Collapse Surface Approach. Canadian Geotchnical Journal, $n^{\circ}$ 22: 564-578, 1985.

SKEMPTON, W. A. The Poro-Pressure Coefficients A and B. Geotechnique, 1954.

SKEMPTON, W. A.; BISHOP, W. A.. The Measurement of the Shear Strength of Soils. First Technical Session, 1950.

VAID, P; THOMAS, J. Liquefaction and Postliquefaction Behavior of Sand. 1985.

VICK, R. Planning, Design, and Analysis of Tailings Dams. Department of Civil Engineering Massachusetts Institute of Technology, 1989.

YAMAMURO, A. J.; LADE, V. P.. Static liquefaction of very loose sands. Canadian Geotechnical Jounal, n 34: 905-917, 1997. 
Apêndice 1 - Resultados dos Ensaios Triaxiais da Areia de Camboinhas. 


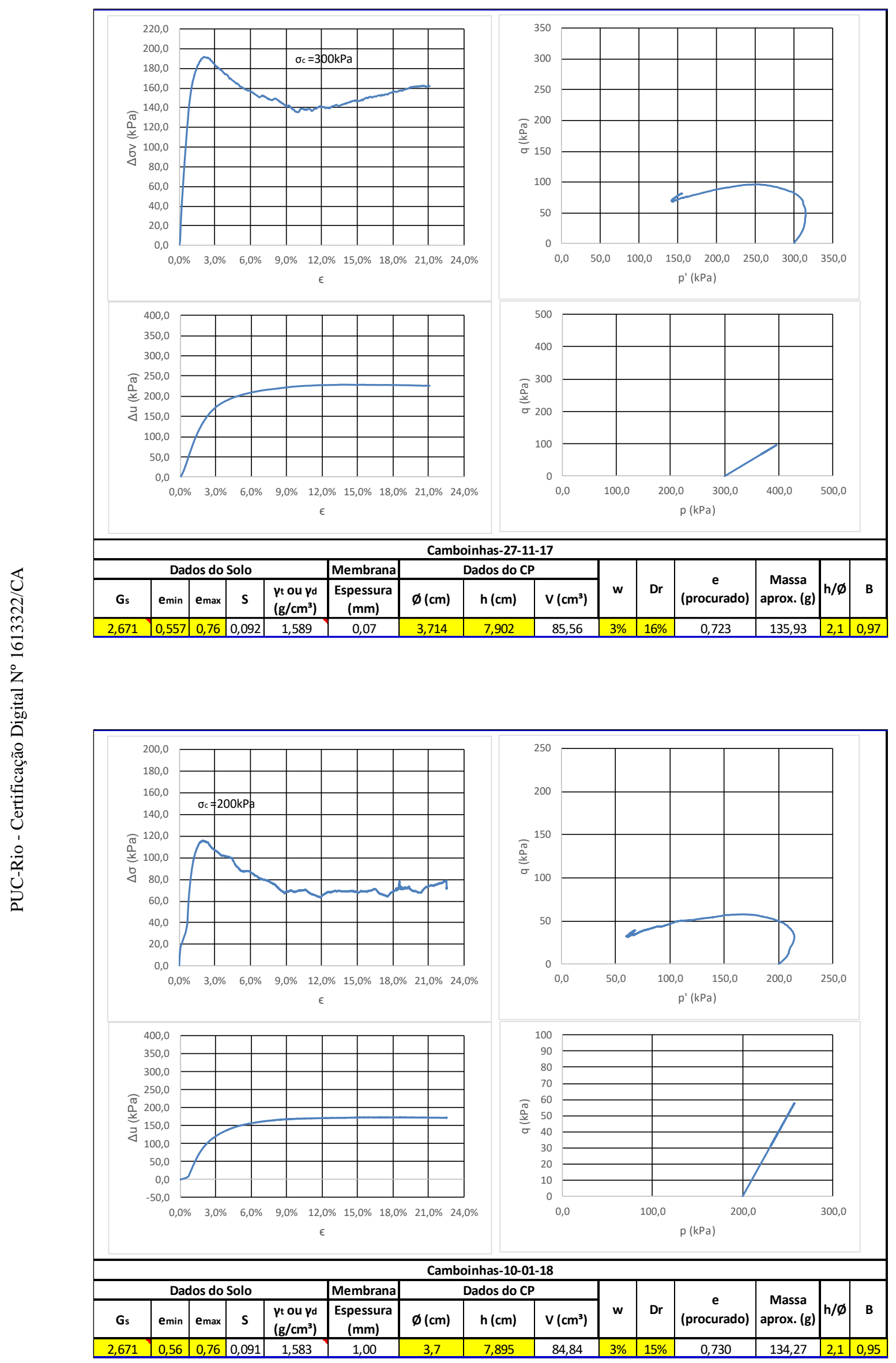



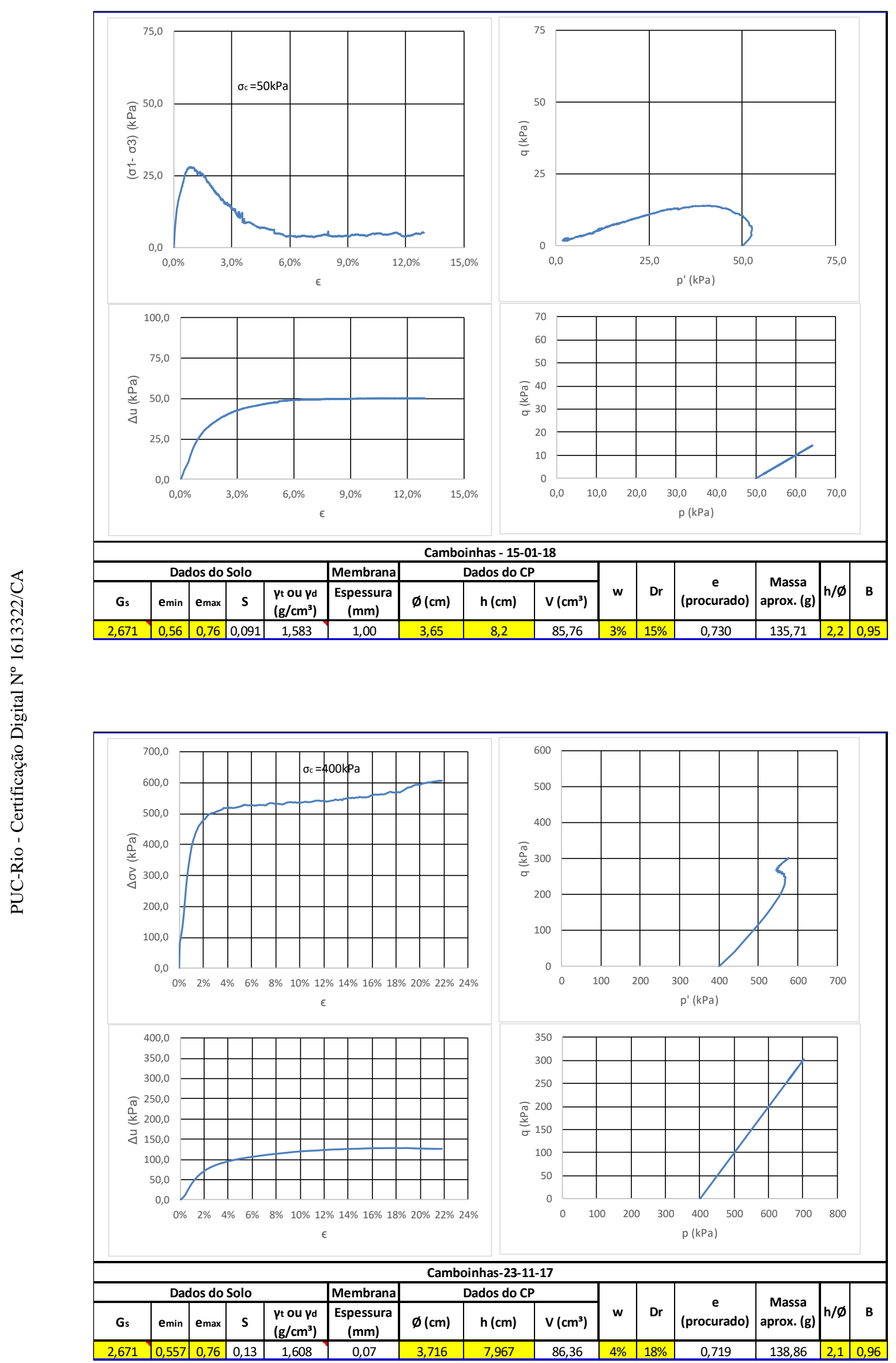
Apêndice 2 - Resultados dos Ensaios Triaxiais do Rejeito Arenoso de Mariana. 


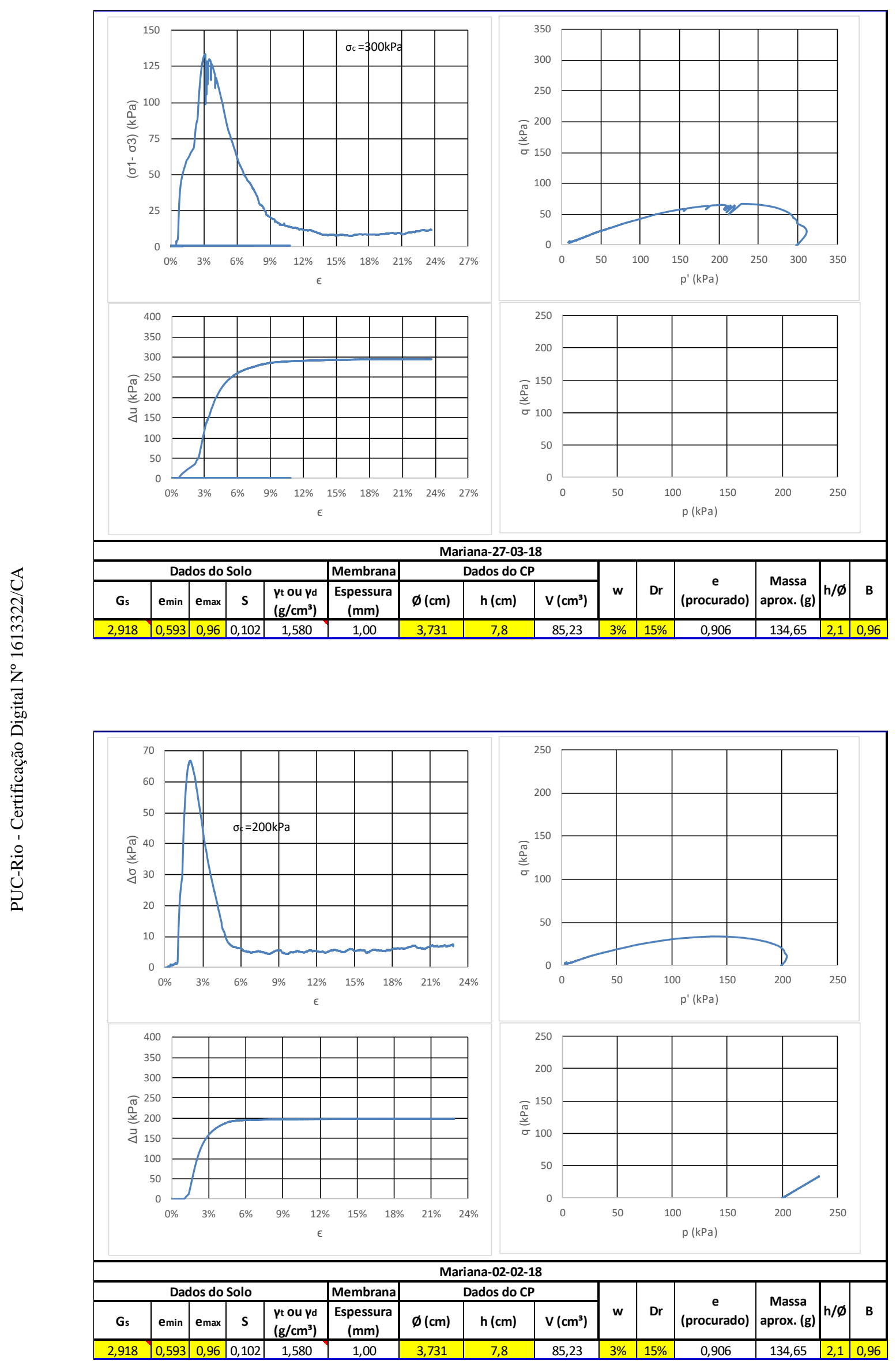




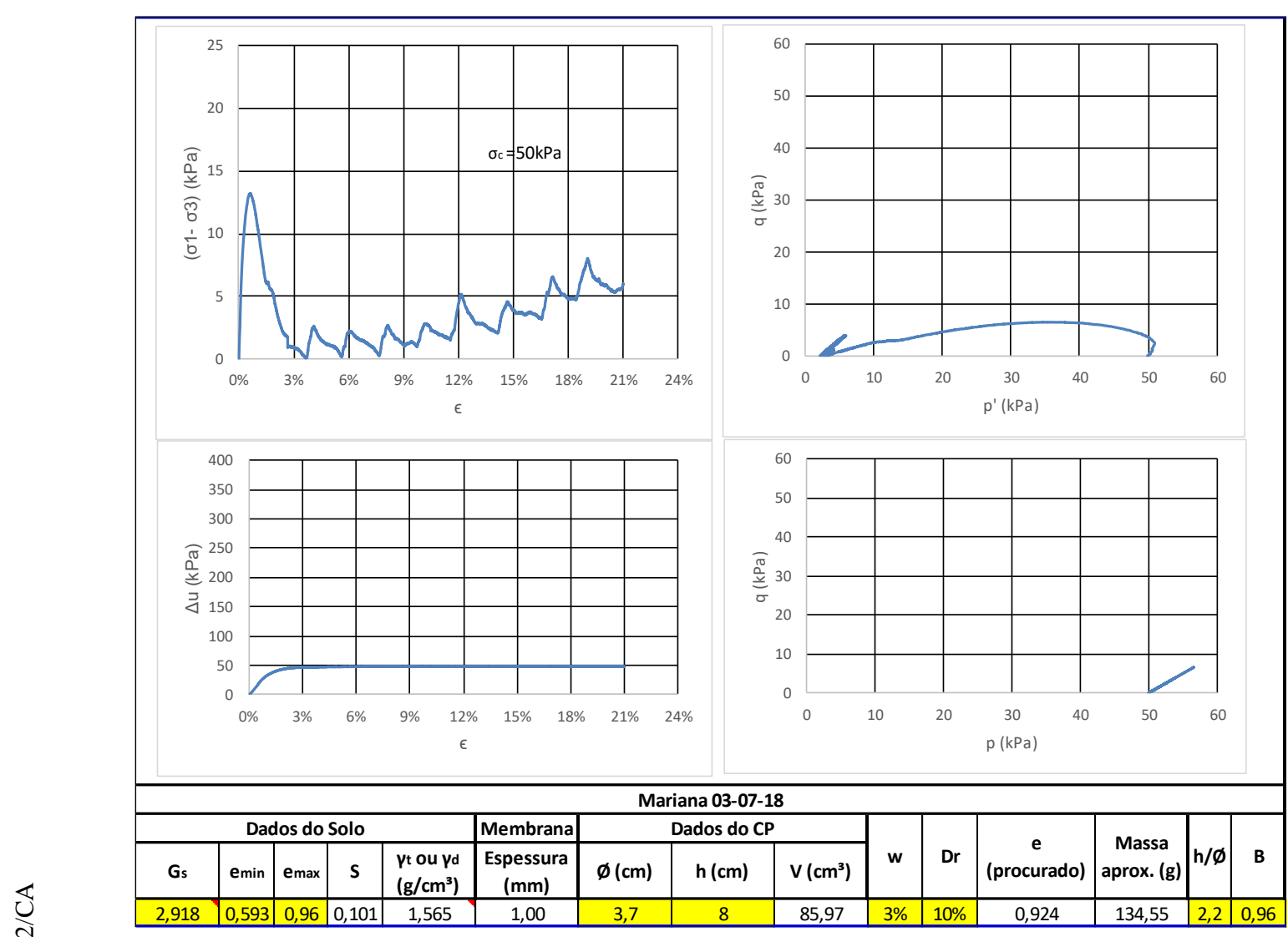

